Conservation

-

Division of Buildings

and

Community Systems

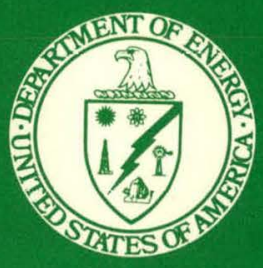

MASTER MASTER

\section{Engineering-Economic Analysis of Mobile Home Thermal Performance}

\author{
Paul F. Hutchins, Jr. \\ Eric Hirst
}




\section{DISCLAIMER}

This report was prepared as an account of work sponsored by an agency of the United States Government. Neither the United States Government nor any agency Thereof, nor any of their employees, makes any warranty, express or implied, or assumes any legal liability or responsibility for the accuracy, completeness, or usefulness of any information, apparatus, product, or process disclosed, or represents that its use would not infringe privately owned rights. Reference herein to any specific commercial product, process, or service by trade name, trademark, manufacturer, or otherwise does not necessarily constitute or imply its endorsement, recommendation, or favoring by the United States Government or any agency thereof. The views and opinions of authors expressed herein do not necessarily state or reflect those of the United States Government or any agency thereof. 


\section{DISCLAIMER}

Portions of this document may be illegible in electronic image products. Images are produced from the best available original document. 


\section{Printed in the United States of America. Available from National Technical Information Service \\ U.S. Department of Commerce \\ 5285 Port Royal Road, Springfield, Virginia 22161 \\ Price: Printed Copy $\$ 8.00$; Microfiche $\$ 3.00$}

This report was prepared as an account of work sponsored by an agency of the United States Government. Neither the United States Government nor any agency thereof, nor any of their employees, contractors, subcontractors, or their employees, makes any warranty, express or implied, nor assumes any legal liability or responsibility for any third party's use or the results of such use of any information, apparatus, product or process disclosed in this report, nor represents that its use by such third party would not infringe privately owned rights. 
ORNL/CON.. 28

Contract No. W-7405-eng-26

ENERGY DIVISION

ENGINEERING-ECONOMIC ANALYSTS OF MOBILE HOME THERMAL PERFORMANCE

Paul F. Hutchins, Jr.

Eric Hirst

Date Published: October 1978

OAK RIDGE NATIUNAL LABORATORY

Oak Ridge, Tennessee 37830 operated by

UNION CARBIDE CORPORATION

for the

DF.PARTMENT OF ENERGY

This report was prepared as an account of work sponsored by the United States Government. Nether the United Siates ner the Fned Slates nor the United Slates Department of Finerpy, nor any of their emplnyees. nnr any of their

contractors, subcontractors, or their employees, makes

any warranty, express or implied, or assumes any legal

liability or responsibitity for the accuracy, completeness

or usefulness of any information, apparatus, product of

process disclosed, or represents that its use would not

infringe privately owned rights. 
THIS PAGE

WAS INTENTIONALLY

LEFT BLANK 


\section{ABSTRACT}

Various levels of investment in energy-efficient designs are studied for new mobile homes. The purpose is to define relationships between annual energy use for space heating and cooling and additional initial investment in the structure shell for a range of climates in the United States. Climate, fuel price, and other economic factors are used to determine which energy conserving designs are cost-effective. Maximum lifecycle savings configurations for a typical $14^{\prime} \times 68^{\prime}$ mobile home are developed for nine different locations in the U.S.

Annual heating and cooling requirements are determined using NASA's Energy-Cost Analysis Program (NECAP). The computer code provides an hour-by-hour dynamic simulation of heat flows through a structure using U.S. Weather Bureau weather tapes. Cost information for the different design options was obtained from merchandise catalogues, construction data handbooks, and nationwide surveys.

Results show that the maximum reduction in annual energy consumption (disregarding economics) is about $60 \%$ of the baseline figure for heating and about $25 \%$ for cooling. In most climates this corresponds to a $30 \%$ saving in space heating relative to a mobile home built to meet the 1976 federal (HUD) standard and a 15\% saving for cooling. In the milder areas (less than 2000 heating degree days) this means about $20 \%$ heating and $10 \%$ cooling load reductions.

The optimum level of investment (i.e., maximum lifecycle savings) varies by location and heating fuel choice as well as other factors. 
For natural gas heating the energy use reduction is $20-30 \%$ relative to the 1976 HUD standard for all but the warmest climates, in which there are only slight savings. For electric heating or liquid propane (LP), the energy reduction is $30-50 \%$ of the 1976 HUD standard home in northern climates and intermediate areas, but negligible for warmer areas. Energy conserving design options result in savings for cooling which range from 5 to $10 \%$, but could actually increase energy consumption for cooler coastal areas (i.e., Seattle, Boston, and San Diego) by decreasing infiltration of cool nighttime breezes. Paybacks are generally less than five years for any location using natural gas for heating, and less than two for those using electricity or liquid propane gas.

Results from these analyses indicate that even the recent 1976 HUD standard requires considerably less investment in energy-efficient design than what is cost-effective for all but the warmest areas in the U.S. The present standard also neglects to account for different fuel choices (and prices) which affect the economics of the decision process. Results from this analysis should be helpful in assessing energy efficient design alternatives for different locations, fuel choices, and other pertinent variables.

\section{ACKNOWLEDGMENTS}

We appreciate the careful reviews of this document in draft form from Car1 Blumstein, Roger Carlsmith, Jack Gibbons, David Harrje, Stan Johnson, John Moyers, Steve Petersen, Mark Shaurette, and Bill Snyder. 
TABLE OF CONTENTS

SECTION

PAGE

I. INTRODUCTION . . . . . . . . . . . . . . . . . . 1

II. DEFINITION OF MOBILE HOME . . . . . . . . . . . . . . 8

Description . . . . . . . . . . . . . . . 8

Locations . . . . . . . . . . . . . . . 15

III. ANNUAL HEATING AND COOLING LOADS . • . . . . . . . . . . 18

IV. ECONOMIC ANALYSIS . . . . . . . . . . . . . . . . 21

V. RESULTS AND INTERPRETATION . . . . . . . . . . . . . 28

Engineering Analysis .. . . . . . . . . . . 28

Economic Analysis.. . . . . . . . . . . . . . . 36

Sensitivity Analysis . . . . . . . . . . . . . 48

VI. CONTINUOUS ANALYSIS . . . . . . . . . . . . . . . . 57

VII. SUMMARY AND CONCLUSTONS . . . . . . . . . . . . . . 66

REFERENCES . . . . . . . . . . . . . . . . . . . . . . . 71

APPENDIXES . . . . . . . . . . . . . . . . . . . . . . . 75

A. NECAP - PROGRAM DESCRIPTION AND INPUT DATA . . . : . . . . . 77

B. ECONOMIC ANALYSIS PROGRAM LISTING . . . . . . . . . . . . . 97

C. ANALYSIS RESULTS FOR ALL LOCATIONS . . . . . . . . . . . . . 103

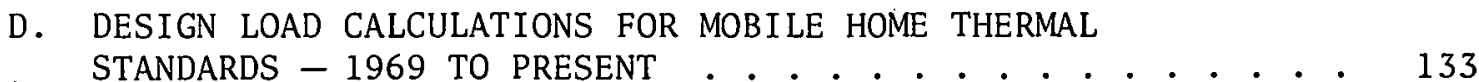




\section{INTRODUCTION}

This report presents a detailed analysis of different levels of investment in energy-efficient designs for new mobile homes. The purpose is to define relationships between annual energy use for mobile home space heating and air conditioning as functions of initial investment in the structure for a range of climates in the United States. These relationships are then used to define the "optimum" design configuration for mobile homes in each location. The optimum is defined as the design configuration that minimizes the lifecycle cost of mobile home purchase plus space heating and cooling operating costs. The optimum differs from location-to-location within the U.S. because of differences in climate, fuel prices, tax, insurance and interest rates.

Results from this analysis should be useful to government policymakers involved with the development of thermal performance standards, such as those required by the federal Energy Conservation and Production Act of 1976 (ECPA). ${ }^{1}$ Title III of ECPA requires development and implementation of ". . performance standards for new residential and commercial buildings . . to achieve maximum practicable improvements in energy efficiency and increases in the use of nondepletable sources of energy.". The approach developed here allows the selection of such "maximum practicable improvements" for a variety of circumstances, thus allowing the development of more flexible standards.

These results should also be useful to manufacturers and purchasers $\therefore \quad$ of new mohile homes. The results suggest which design changes are 
cost-effective in various parts of the country. Also, the methodology developed could be used by the manufacturers to help them decide how much additional investment in energy conservation to make in their designs, on the basis of their particular markets.

Finally, these results will be incorporated into the Oak Ridge National Laboratory (ORNL) residential energy use simulation model. ${ }^{2}$ The simulation model, developed for the Department of Energy, is being used to evaluate the national and regional energy consumption and direct economic effects of various energy conservation policies, programs, and technologies.

Previous work in this area has been limited. Ball, ${ }^{3}$ at ORNL, dealt with energy savings for various retrofit options for a mobile home in Oak Ridge, Tennessee. Measured data were used to develop a dynamic model to compute changes in annual energy consumption. Teitsma and Peavy, ${ }^{4}$ at the National Bureau of Standards, conducted tests on a mobile home located in an environmental climatic laboratory. Important measurements on air infiltration were made there. The most complete and detailed analysis was done by Wilson, ${ }^{5}$ also at ORNL. He used the NBSLD Heating and Cooling Loads Calculation Program to predict energy savings for different levels of insulation and/or storm windows for several locations. Brief calculations on payback periods were also included.

Mobile homes have been produced for more than 25 years. The number of units sold and in use has increased steadily since then. Financial institutions can now make loans on mobile home purchases through such means as the Federal Housing Administration, Veterans' Administration, 
and Farmers' Home Administration. Since June 1976, all new mobile homes must be built to meet the federal Mobile Home Construction and Safety Standards, ${ }^{6}$ promulgated by the Department of Housing and Urban Development. Before then, most states required compliance with the Mobile Home Standard developed by the National Fire Protection Association and the American National Standards Institute (A119.1/NFPA 501B). ${ }^{7}$ This ANSI/NFPA standard has been in existence for more than a decade. Both the HUD and ANSI/NFPA standards require minimum levels of thermal performance for new mobile homes.

Although mobile homes currently account for only a small share of the existing housing stock (4.3\% in 1975), they account for about half of all new single family housing produced for sale each year. ${ }^{8}, 9$ The number of occupied mobile homes has been increasing rapidly. For example, between 1970 and 1975, the number of occupied mobile homes increased $69 \%$ (from $3.1 \%$ of the total housing stock in 1970 to $4.3 \%$ in 1975) while the number of single-family detached homes increased on $1 y 10 \%{ }^{8}$ Table 1 shows the growth in mobile home occupancy during this six-year period for the Census regions and divisions. ${ }^{8}$

The average size of new mobile homes has been increasing, from an average of $12^{\prime} \times 57^{\prime}\left(689 \mathrm{ft}^{2}\right)$ in 1969 to $14^{\prime} \times 69^{\prime}\left(966 \mathrm{ft}^{2}\right)$ in $1976 .^{9}$ This represents a $40 \%$ increase in floor space. During this same period the average size of on-site constructed single-family units remained essentially constant. "Double-wides" (two sections combined horizontally at the site) now account for more than $25 \%$ of total mobile home shipments; this share is increasing each year. 
TABLE 1

EXISTING HOUSEHOLDS IN MOBILE HOMES

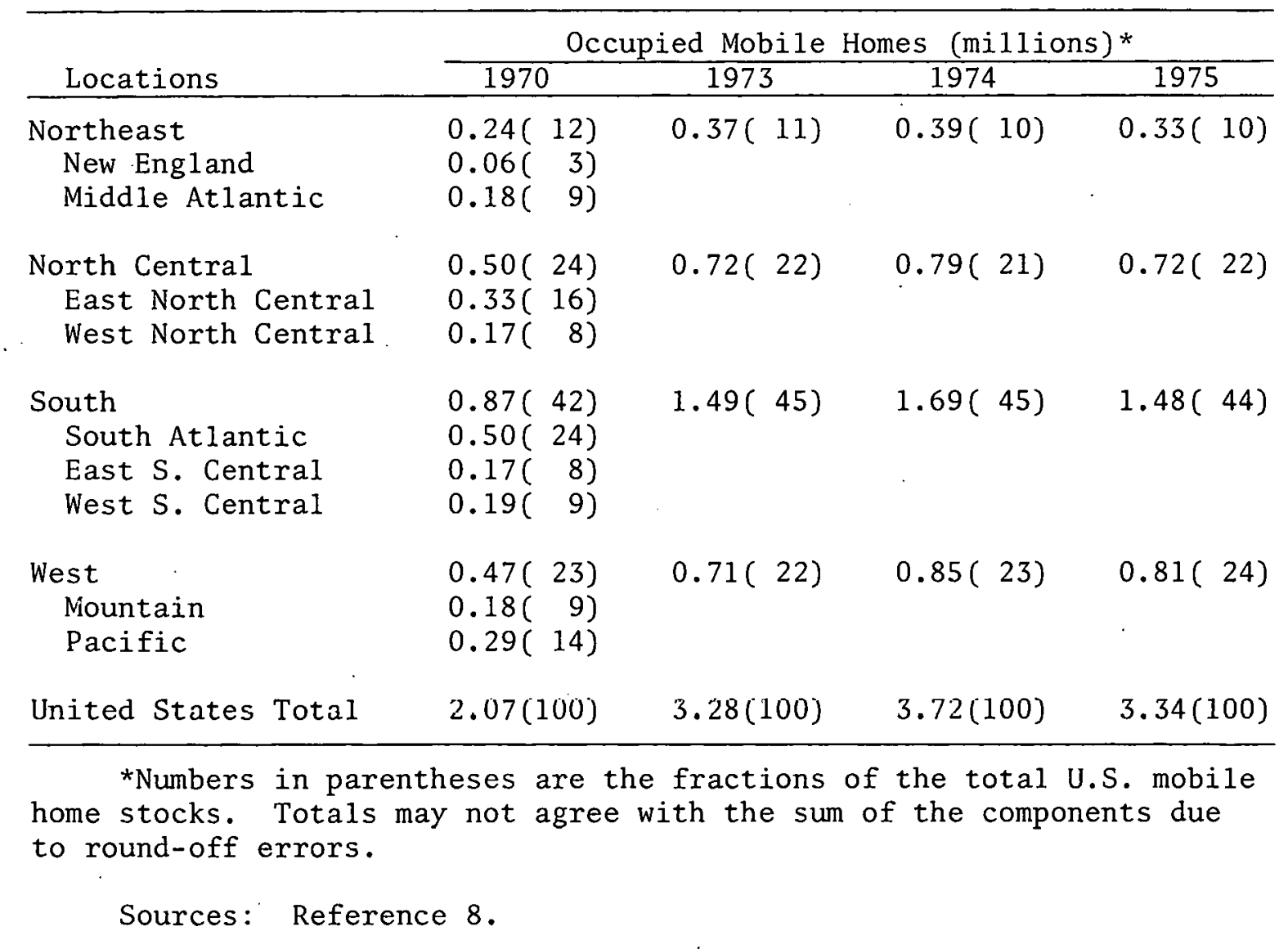


The major reason that mobile homes are becoming increasingly popular is their low price. According to the Manufactured Housing Institute, mobile homes account for $76 \%$ of the new homes sold for less than $\$ 30,000$, and for $96 \%$ of the new homes sold for less than $\$ 20,000$ in $1976 .{ }^{9}$ Most mobile homes are sold to young married couples and to those near retirement. Both groups are particularly vulnerable to inflation and rising operating (fuel) costs because of their limited incomes. Therefore it is particularly important to design mobile homes so that the lifecycle costs of owning and operating these units are kept as low as possible.

Thermal standards to reduce energy use should be economically justifiable on the basis of minimizing the costs of owning and operating the mobile home. In the past, thermal standards were based primarily on the judgments of mobile home industry and government personnel. Little analysis or field data were available to assist in the development of cost-effective standards.

The analytical approach used in this study is shown schematically in Figure 1. Annual heating and cooling loads for mobile homes are calculated with a thermal loads computer code called NECAP ${ }^{10}$ (NASA's Energy-Cost Analysis Program). This code performs an hour-by-hour simulation of heat flows into and out of a user-defined structure using weather data tapes. Outputs arc annual energy requirements to be supplied by HVAC systems plus instantaneous peak heating and cooling demands (needed to calculate the size and cost of heating and cooling equipment). These annual and peak loads from NECAP serve as input to 
ORNL-DWG 78-4598

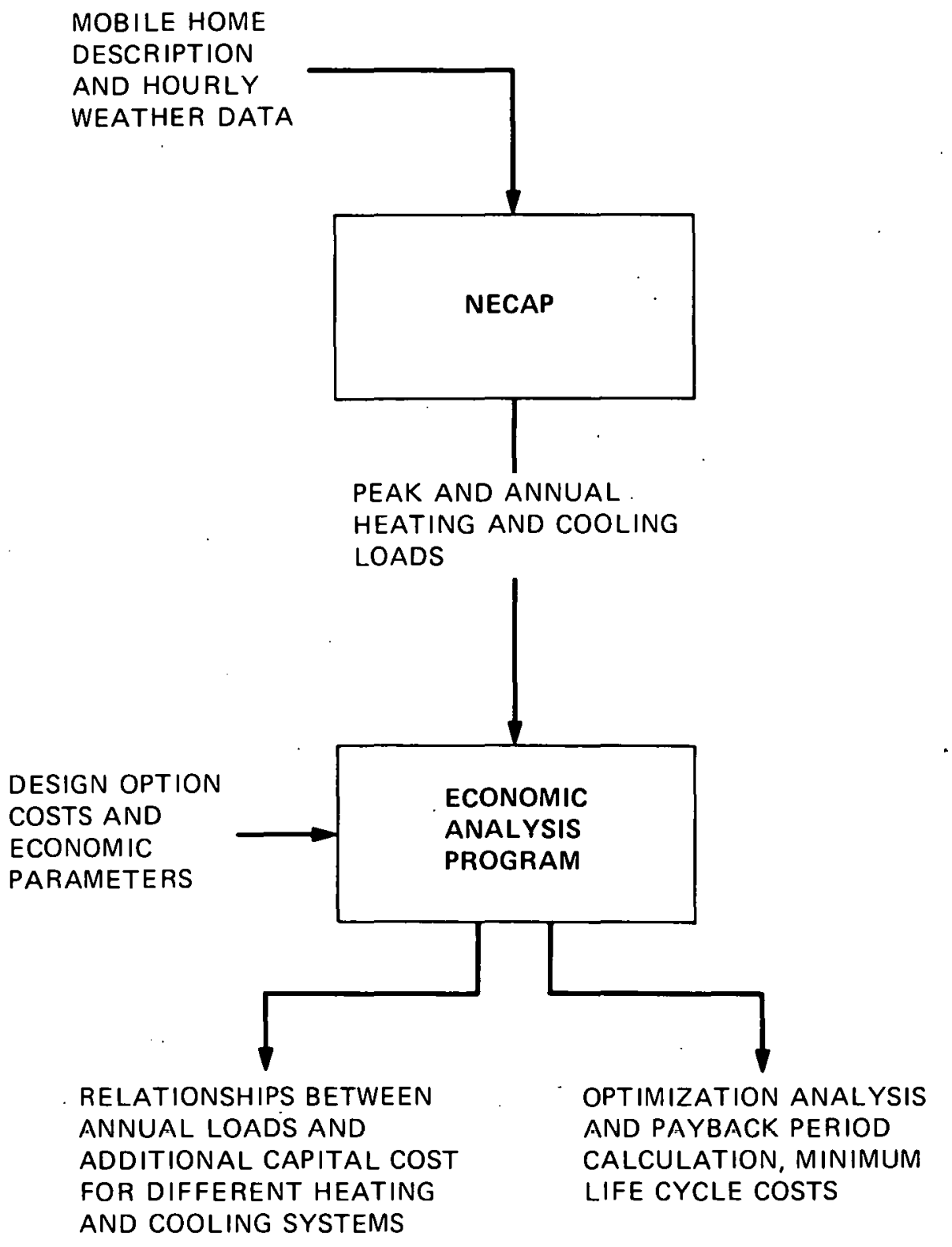

Figure 1. Method of analysis flowchart. 
the Economic Analysis Program. Here, the costs for each design option plus other data (fuel prices, interest rates, etc.) are combined to evaluate the relationships between annual energy use and capital cost and to define the optimal (minimum lifecycle cost) design option.

The remainder of this report is organized as follows. Section II contains a description of the mobile home and the locations to be studied. The method for computing the annual heating and cooling loads is discussed in Section III. Section IV describes the techniques used in performing the economic analysis. Results of the loads, economic, and sensitivity analyses are found in Section V. A continuous analysis is presented in Section VI with the summary and conclusions in Section VII. 


\section{DEFINITION OF MOBILE HOME}

Description

To reduce the magnitude of this analysis a single, characteristic mobile home was selected for all geographic locations. This should not introduce any serious inaccuracies as variations in mobile home construction practices across the United States should not significantly affect heat flows across the building shell.

Using data supplied by the Manufactured Housing Institute ${ }^{11}$ and the National Fire Protection Association/American National Standards Institute, ${ }^{12}$ a mobile home, typical of those sold in 1975, was defined. A list of general dimensions describing this baseline mobile home is in Table 2 .

TABLE 2

MOBILE HOME DIMFNSTIONS

$\begin{array}{lr}\text { Width (feet) } & 14 \\ \text { Length (feet) } & 68 \\ \text { Wall height (feet) } & 7.5 \\ \text { Side wall window area (\% of floor area) } & 9.0 \\ \text { End wall window area (\% of floor area) } & 3.3 \\ \left.\text { Side wall door area, two doors (ft }{ }^{2}\right) & 34 \\ \text { Effective volume, minus furniture and interior partitions (ft }{ }^{3} \text { ) } & 5,712 \\ \text { Underpinning height (feet) } & 2.5\end{array}$

Maximum amounts of insulation are limited by the dimensions of the various wall, ceiling/roof, and floor cavities. The largest available in a $14^{\prime}$ single-wide mobile home today allows a $3-1 / 2$ " wall cavity, 
6" for the ceiling (5-1/2" eave height dimension) and 5-1/2" in the floor without excessive compression. It should be noted, however, that current floor construction practices cause a decrease in overall effectiveness of the insulation when floor joists are placed over a continuous mat of insulation (see Appendix A, Figure A-4). Decreased effectiveness may also result from poor installation procedures which are not investigated here. More detailed construction characteristics necessary for an accurate computer simulation are contained in Appendix A. Mobile home internal loads were estimated from data on single-family detached dwelling energy consumption ${ }^{13}$ and are listed in Table 3 .

T'ABLE 3

MOBILE HOME INTERNAL LOADS

\begin{tabular}{lc}
\hline Occupants & 2 Adults \\
Lighting (kwhr/year) & 1 Child \\
Equipment (kwhr/year) & 1,270 \\
Refrigerator & 1,400 \\
Oven/range & 1,000 \\
TV & 400 \\
Dishwasher & 280 \\
Miscellaneous & $\underline{1,100}$ \\
Total equipment (kwhr/year) & 4,180 \\
\hline
\end{tabular}

The baseline design has one inch of fiberglass insulation (R-value $\approx 3.16 \mathrm{hr}-\mathrm{ft}^{2}-{ }^{\circ} \mathrm{F} /$ Btu per inch thickness) in the walls, floor, and ceiling. 
This represents a minimum amount of thermal protection, slightly less than that required by the 1969 ANSI standard.*

The design options studied include only those currently available to the consumer on new mobile homes. These nonretrofit options do not affect occupant lifestyle (i.e., completely permanent and passive and no radical changes in typical construction practices) and improve the thermal integrity of the structure:

1. additional fiberglass insulation in the wal1s, ceiling, and floor

2. insulated wall sheathing

3. storm windows

4. underpinning (skirts)

5. orientation

6. awnings

In the baseline design the mobile home is positioned such that the longer outside wall surface is normal to a vector $45^{\circ}$ east of due North $(\mathrm{SE}-\mathrm{NW})$. Two other orientations were considered - one where the shorter outside wall surfaces are facing due East-West (designated E-W), and the other where the shorter surfaces face due North-South (N-S). Although the largest solar load is from the East and West, awnings are of little use on these sides due to the low sun angles. Devices such

*A minimum level of insulation equal to one inch in the walls, ceiling and floor was used to alleviate the problem of estimating manufacturers' labor costs. Labor costs for installing various thicknesses of insulation are basically constant. Therefore, additional investment in insulation above the one inch baseline does not include labor costs which are difficult to estimate. 
as window blinds would be beneficial, but require operational activity by the owner to be effective and, therefore, are not evaluated here. Awnings were placed only on those windows whose outward-facing normals had components in the due South direction. The baseline configuration is defined in terms of these six options.

1. 1" fiberglass insulation in walls, floor, ceiling

2. no insulated wall sheathing

3. no storm windows

4. no underpinning

5. no awnings

6. $45^{\circ}$ orientation (i.e., SE-NW)

Costs for each design option were collected from cost data manuals, ${ }^{14,15,16}$ merchandise catalogues, ${ }^{17,18,19}$ surveys of related literature ${ }^{3}$ and dealers in mobile home products. Figures from the various sources were combined including dealer mark-up, and an average consumer retail price was computed. Local price variations are accounted for later in the Economic Analysis Section. The calculated costs (in 1975 dollars) represent the incremental expense to the consumer as a result of purchasing a mobile home design with energy-efficient options in addition to those present in the baseline configuration.

Orientation costs are estimated based on expected increased expenses for masonry and possible excavation for site preparation. Table 4 lists the associated costs and information sources for each of the design options considered. 
TABLE 4

DESIGN OPTION COST DATA*

\begin{tabular}{|c|c|c|c|c|}
\hline Item & $\begin{array}{l}\text { Average } \\
\text { Unit Cost } \\
(1975-\$) \\
\end{array}$ & Amount & $\begin{array}{c}\text { Additional } \\
\text { Costs** } \\
(1975-\$) \\
\end{array}$ & Source \\
\hline $\begin{array}{l}\text { Wall insulation } \\
1^{\prime \prime}-2^{\prime \prime} \text { fiberglass batt*** } \\
2^{\prime \prime}-3.5 \text { " fiberglass batt } \\
1 / 4 " \text { insulated sheath. }\end{array}$ & $\begin{array}{l}3.65 \phi / \mathrm{ft}^{2}-\text { in } \\
3.65 \$ / \mathrm{ft}^{2}-\text { in } \\
13.4 \phi / \mathrm{ft}^{2} \text { (gross) }\end{array}$ & $\begin{aligned} 944 \mathrm{ft}^{2} \\
944 \mathrm{ft}^{2} \\
1230 \mathrm{ft}^{2} \text { (gross) }\end{aligned}$ & $\begin{array}{r}35 \\
53 \\
164\end{array}$ & $\begin{array}{l}14,15 \\
14,15\end{array}$ \\
\hline $\begin{array}{l}\text { Ceiling insulation } \\
1^{\prime \prime}-3.5^{\prime \prime} \text { fiberglass batt } \\
3.5^{\prime \prime}-6^{\prime \prime} \text { fiberglass batt }\end{array}$ & $\begin{array}{l}3.65 \phi / f t^{2}-\text { in } \\
3.65 \$ / f t^{2}-\text { in }\end{array}$ & $\begin{array}{l}833 \mathrm{ft}^{2} \\
833 \mathrm{ft}^{2}\end{array}$ & $\begin{array}{l}76 \\
76\end{array}$ & $\begin{array}{l}14,15 \\
14,15\end{array}$ \\
\hline $\begin{array}{l}\text { Floor insulation } \\
1^{\prime \prime}-3.5^{\prime \prime} \text { fiberglass batt } \\
3.5^{\prime \prime}-5.5^{\prime \prime} \text { fiberglass batt }\end{array}$ & $\begin{array}{l}3.65 \phi / f t^{2}-i n \\
3.65 \phi / f t^{2}-i n\end{array}$ & $\begin{array}{l}952 \mathrm{ft}^{2} \\
952 \mathrm{ft}^{2}\end{array}$ & $\begin{array}{l}87 \\
69\end{array}$ & $\begin{array}{l}14,15 \\
14,15\end{array}$ \\
\hline Underpinning & $\$ 2.60 / f t$ & $164 \mathrm{ft}$ & 426 & $3,16,17$ \\
\hline Awnings & $\begin{array}{l}\$ 3.00 / f t^{2} \\
\text { (windows) }\end{array}$ & $75 \mathrm{ft}^{2}$ & 225 & 16,17 \\
\hline Orientation & - & - & 60 & \\
\hline Storm windows & $\begin{array}{l}2.25 / \mathrm{ft}^{2} \\
\text { (windows) }\end{array}$ & $117 \mathrm{ft}^{2}$ & 263 & \\
\hline
\end{tabular}

*For a $14^{\prime} \times 68^{\prime} \times 7.5^{\prime}$ mobile rome.

** Labor costs for insulated sheathing, underpinning, awnings, orientation, and storm windows are $\$ 80, \$ 200, \$ 110, \$ 60$ and $\$ 130$, respectively. All others are zero.

***option involves replacing a 1 " fiberglass batt with a 2 " fiberglass batt with R-value of $3.16 \mathrm{hr}-\mathrm{ft}^{2}-{ }^{\circ} \mathrm{F} / \mathrm{Btu}$ per inch thickness. 
As the thermal performance of the structure is improved, the size of heating or cooling equipment needed to meet the most severe climate conditions in a location, the design or peak load, becomes smaller. To account for these savings, incremental cost data for typical mobile home HVAC equipment were gathered from merchandise catalogues ${ }^{18,19}$ and surveys of mobile home dealers so that the resulting amount would be the cost to the consumer. The average incremental cost (1975 dollars) to the consumer for gas (or electric) heating and air conditioning equipment for mobile homes is approximately $\$ 2.50$ per $\mathrm{kBtu} / \mathrm{hr}(\mathrm{kBtu}=$ $10^{3} \mathrm{Btu}$ ) and $\$ 16$ per $\mathrm{kBtu} / \mathrm{hr}$ output, respectively. The amounts do not include labor costs, as savings due to HVAC equipment size reductions assume that such systems are present in the baseline design to allow these size reductions. The analyses deal with both the cases of heating only and heating plus air conditioning.

The heating fuel choices in new mobile homes in 1976-1977 for the nine Census Regions are shown in Table $5 .^{20}$ Gas represents about half of the U.S. total, electricity $41 \%$, and oil the remainder. Electricity dominates in the southeastern areas and Mountain Region and oil in the New England Regiun and slightly in the Middle Atlantic Region. Gas dominates elsewhere with greater than $25 \%$ contribution in all regions. Since gas and electricity are the major heating sources and the oil choice is declining yearly, the types studied are natural gas, liquid propane gas (LP) and electricity. However, the analysis is general enough to allow substitution of oil for gas by adjusting fuel prices and combustion efficiencies. 
TABLE 5

DISTRIBUTION OF HEATING FUEL TYPES FOR NEW MOBILE HOMES, 1976-1977

\begin{tabular}{|c|c|c|c|c|c|c|c|c|c|c|}
\hline $\begin{array}{l}\text { Heating Fuel } \\
\text { Source }\left(\frac{\%}{0}\right)\end{array}$ & $\begin{array}{c}\text { New } \\
\text { England } \\
\end{array}$ & $\begin{array}{l}\text { Mid- } \\
\text { Atlantic }\end{array}$ & $\begin{array}{l}\text { East } \\
\text { North } \\
\text { Central }\end{array}$ & $\begin{array}{l}\text { West } \\
\text { North } \\
\text { Central }\end{array}$ & $\begin{array}{l}\text { South } \\
\text { Atlantic }\end{array}$ & $\begin{array}{l}\text { East } \\
\text { South } \\
\text { Central }\end{array}$ & $\begin{array}{l}\text { West } \\
\text { South } \\
\text { Central }\end{array}$ & Mountain & Pacific & $\begin{array}{l}\text { U.S. } \\
\text { Total } \\
\end{array}$ \\
\hline Gas* & 27.4 & 31.7 & 523 & 57.3 & 41.0 & 41.9 & 64.8 & 41.1 & 57.8 & 49.7 \\
\hline Oil & 53.9 & 35.6 & 10.4 & 9.3 & 11.4 & 2.7 & 2.2 & 5.5 & 2.4 & 9.0 \\
\hline Electric & 18.7 & 32.7 & 37.3 & 33.4 & 47.6 & 55.4 & 33.0 & 53.4 & 39.8 & 41.3 \\
\hline
\end{tabular}

Source: Thermal Characteristics of Single Family Detached, Single Family Attached, Lowrise Multifamily, Mabile Homes for Office of Technology Assessment, Congress of the United States, NAHB Research Foundation, Inc., October 1977.

*Represents both piped (natural gas) and bottled (liquid propane) gas. Approximately $60 \%$ of the U.S. gas total is liquid propane.

Source: Reference 20 . 
Locations

Many factors entered into the selection process for the different sites to be studied. The following were used as guidelines.

1. Include a wide range of values for annual heating and cooling. degree days and humidity.

2. Select only locations which correspond to those readily available on U.S. Weather Bureau tapes ${ }^{21}$ at ORNL.

3. Limit the number of sites to ten.

Nine cities were selected for study, shown in Figure 2. and 1isted in Table 6. Seattle, Boston, Miami, San Diego and Minneapolis were chosen because they represent extreme climate types among densely populated areas. The four remaining cities - Atlanta, Washington, Kansas City, and Cheyenne - were selected as interior points that covered the spectrum of weather between the previously chosen extremes. 


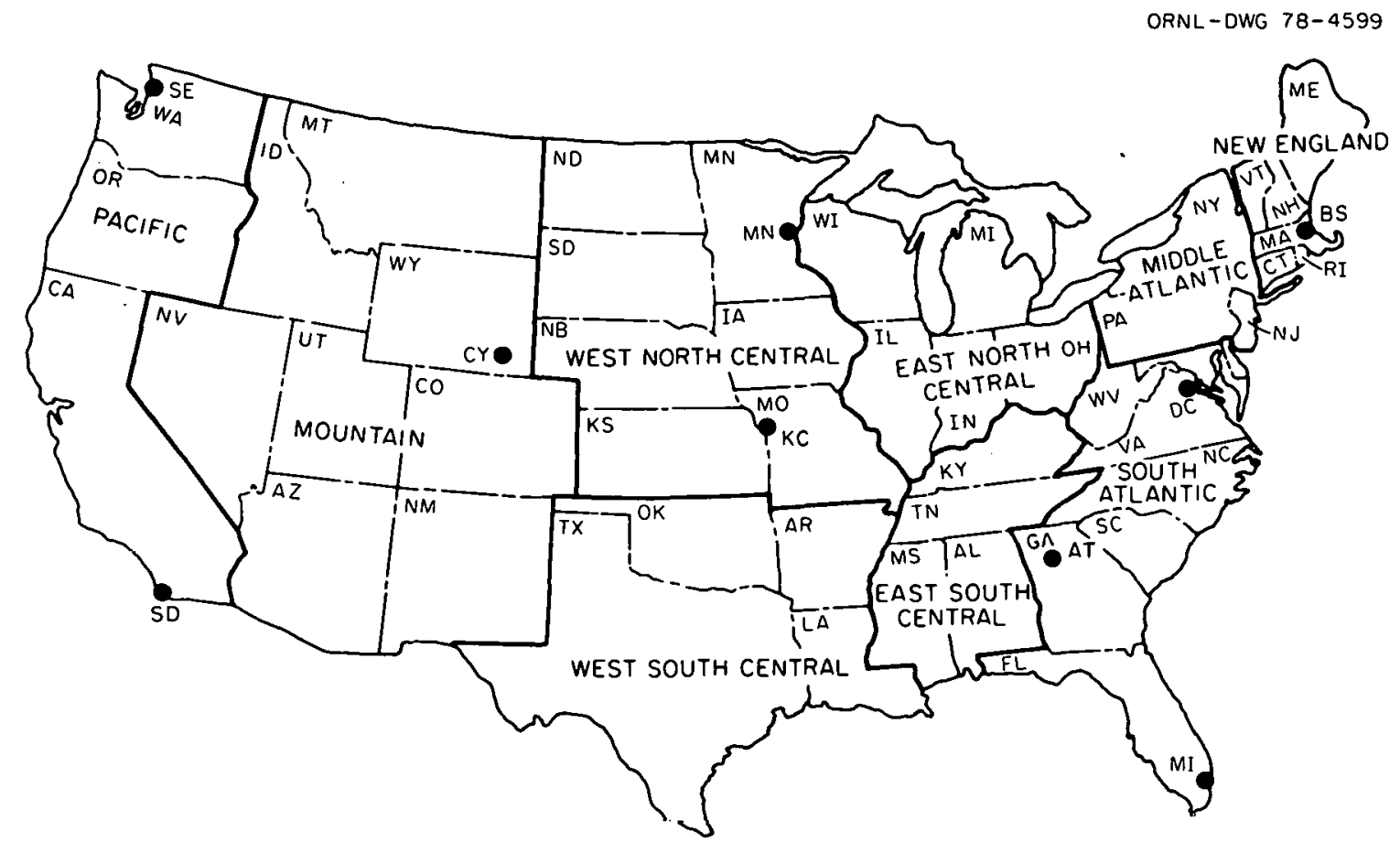

Figure 2. Site selections. 
TABLE 6

LOCATIONS FOR ANALYSIS

\begin{tabular}{llcccc}
\hline Code & \multicolumn{1}{c}{ City } & $\begin{array}{c}\text { Weather Tape } \\
\text { Year }\end{array}$ & \multicolumn{2}{c}{ Annual Degree Days* } \\
& Minneapolis & 1956 & 7,983 & 700 & $5 / 15-9 / 16$ \\
CY & Cieyenne & 1960 & 7,265 & 476 & $4 / 1-11 / 1$ \\
BS & Boston & 1962 & 6,084 & 541 & $5 / 15-10 / 1$ \\
SE & Seattle & 1956 & 5,673 & 114 & $5 / 15-9 / 15$ \\
KC & Kansas City & 1962 & 5,068 & 1,656 & $4 / 1-11 / 1$ \\
DC & Washington, D.C. & 1958 & 4,661 & 1,199 & $4 / 15-10 / 15$ \\
AT & Atlanta & 1958 & 3,048 & 1,324 & $4 / 1-11 / 1$ \\
SD & San Diego & 1961 & 1,254 & 670 & $7 / 15-11 / 15$ \\
MI & Miami & 1955 & 153 & 3,834 & $1 / 1-12 / 31$ \\
\hline
\end{tabular}

*Base temperature is $65^{\circ} \mathrm{F}$. 


\section{I. ANNUAL HEATING AND COOLING LOADS}

To accurately calculate heating and cooling loads for a variety of design modifications to the mobile home, a sophisticated building design and energy analysis tool is necessary. From those publicly available, $\operatorname{NECAP}^{10}$ was selected because of its nationwide acceptance,* ability to handle complex construction design, and accessibility at ORNL.

The version of NECAP used for this analysis was prepared by the General American Research Division of the General American Transportation Corporation for NASA's Langley Research Center. The program uses state-of-the-art algorithms recommended by ASHRAE (American Society of Heating, Refrigeration and Air Conditioning Engineers). ${ }^{23}$ Taking account of the building's thermal storage, it calculates hourly heat flows across each surface of the structure shell, based on inside and outside temperatures, solar insolation, internal loads and wind velocity. Infiltration varies as a function of wind velocity and the insideoutside temperature difference. Annual loads are the sums of calculations for each of the 8,760 hours in the year.

There are six different programs in the NECAP code: Response Factor, Data Verification, Thermal Loads Analysis, Variable Temperature, System and Equipment Analysis, and Owning and Operating Cost Programs. Three of these, the Response Factor (RF), Thermal Loads Analysis (TLA),

\footnotetext{
*Validation of NECAP has demonstrated excellent agreement with field measurements. These results are documented in Reference 22 .
} 
and Variable Temperature (VT) Programs were used in this study. These parts of the NECAP code, their relationships to one another, and information flows between them are shown schematically in Figure 3 . The RF Program defines the transient thermal performance of the building shel1. The resulting output of the RF Program plus building geometry, orientation, window and door information, infiltration and internal loads characteristics, etc., are combined with hourly weather data to complete the inputs used by the TLA Program. This program produces a peak load summary and data tape of the building hourly loads based on a constant indoor temperature. This tape plus additional information on thermostat and HVAC equipment operation profiles are input to the VT Program which yields the final results, total annual heating and cooling loads. A detailed description of the inputs used to model the mobile home using NECAP are in Appendix A. 


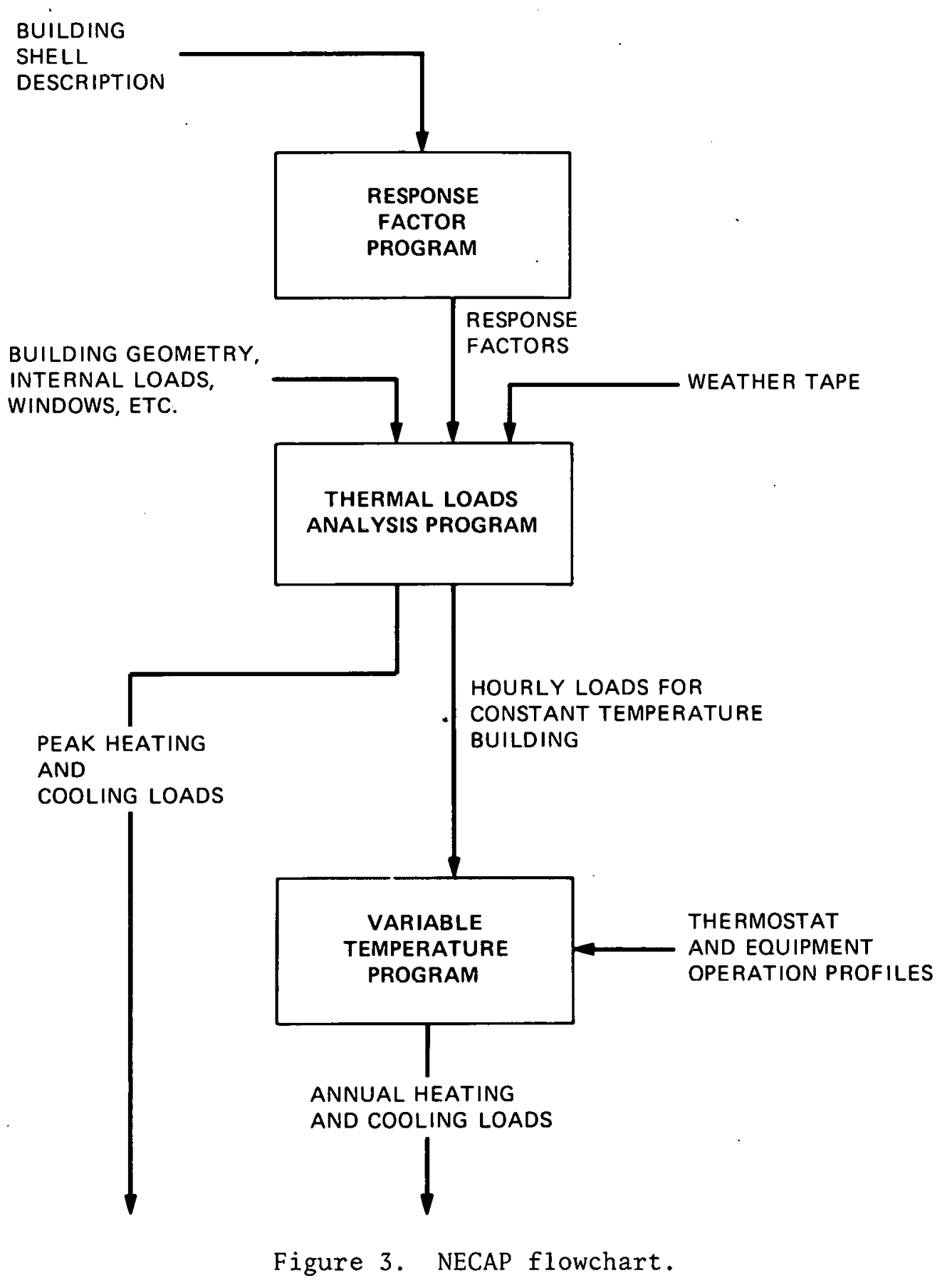




\section{ECONOMIC ANALYSIS}

The Economic Analysis Program performs three tasks:

1. Develops relationships between annual heating and cooling loads and additional investment in thermal improvements.

2. Calculates payback period and net present worth (using lifecycle cost analysis) of each design option so one may select the optimum.

3. Performs sensitivity analyses to determine the effects on above results for changes in various input parameters (insurance and tax rates, fuel prices, interest rates, etc.).

The inputs used include peak heating and cooling demands, annual heating and cooling loads, design option additional costs, and other variable parameters. These parameters are engineering and economic factors that affect the total energy-related lifecycle costs for a mobile home. These factors are listed in Table 7.24,25,26 The nominal value column represents average or typical values for each item for locations in the United States. These numbers vary from region to region as indicated by the range values.

The material and labor indices represent the cost of building materials and labor, respectively, relative to the average U.S. price. This factor is multiplied by the average structure or HVAC equipment price to account for regional variations.

In most states the mobile home is considered personal property and is taxed accordingly. Therefore, property taxes are not affected by changes in mobile home market value. The real interest rate is 
TABLE 7

VARIABLE PARAMETER DATA

\begin{tabular}{|c|c|c|c|}
\hline & $\begin{array}{c}\text { Nominal } \\
\text { Value }\end{array}$ & Range* & Source \\
\hline Material cost index & 1.0 & $0.85-1.15$ & 14 \\
\hline Labor cost index & 1.0 & $0.85-1.15$ & 14 \\
\hline State sales tax (\% of mobile home value) & 4.0 & $3.0-7.0$ & 24 \\
\hline $\begin{array}{l}\text { Marginal annual insurance premium (\% of } \\
\text { mobile home value) }\end{array}$ & 2.5 & $2.0-4.0$ & \\
\hline Annual real interest rate $(\%)$ & 5.0 & $\underline{2.0}-11.0$ & \\
\hline Time horizon (years) & 12 & $10-\underline{15}$ & \\
\hline $\begin{array}{l}\text { Seasonal fuel utilization efficiency } \\
\text { Gas heating }(\%) \\
\text { Electric resistance heating }(\%) \\
\Lambda \text { ir conditioning (EER) }\end{array}$ & $\begin{array}{l}60 \\
100 \\
7.0\end{array}$ & $\begin{array}{l}\frac{50-70}{100} \\
6.0-8.0\end{array}$ & 25 \\
\hline $\begin{array}{l}\text { Marginal fuel prices }(\$ / M B t u) * * \\
\text { Natural gas } \\
\text { I.jiquid propane } \\
\text { Elcctricity*** }\end{array}$ & $\begin{array}{l}2.00 \\
6.00 \\
10.00\end{array}$ & $\begin{array}{l}1.00-12.00 \\
1.00-\frac{12.00}{1.70-20.00}\end{array}$ & \\
\hline
\end{tabular}

*Underlined values are those that encourage investment in energyconserving design options.

$* *$ MBtu $=10^{6}$ Btu.

$* * *$ To convert from $\$ / M B$ tu to $\phi / k w h r$, multiply by 0.34 . 
the cost of borrowed money for mobile home financing minus inflation. The discount rate, which should be the lower of the consumer's rate of return on investment or cost of borrowed money, is assumed to be equal to the real interest rate described above. The time horizon for the lifecycle cost analysis is assumed to be equivalent to the loan term.

The relationships between inputs and the Economic Analysis Program results are shown in Figure 4. Peak demand loads from NECAP plus incremental cost data for structure and HVAC equipment are used to compute the additional initial costs for each design option. These are combined with the annual loads data from NECAP to form the annual loads versus additional cost relationships.

The seasonal fuel utilization efficiency (SFUE) is defined as:

$$
\left[\begin{array}{l}
\text { Seasonal fuel } \\
\text { utilization } \\
\text { efficiency }
\end{array}\right]=\left[\begin{array}{l}
\text { Seasonal useful heat } \\
\text { supplied/removed } \\
\text { by the system }
\end{array}\right] \div\left[\begin{array}{l}
\text { Seasonal } \\
\text { fuel } \\
\text { consumption }
\end{array}\right]
$$

The SFUE for air conditioning is defined as

$$
\left[\begin{array}{l}
\text { Seasonal fuel } \\
\text { utilization } \\
\text { efficiency }(A / C)
\end{array}\right]=[\text { Seasonal EER }] \div 3.414
$$

Using these relations (Equations IV-1 and IV-2), the dynamic performance of the HVAC systems are characterized by a single number, SFUE, which is considcrably smaller than the steary-state efficiency. The SFUE is defined to account for duct. losses, inefficiencies in system "on-off" cycling, and overheating wastage that may occur due to system control response mechanisms. 
ORNL-DWG 78-4601

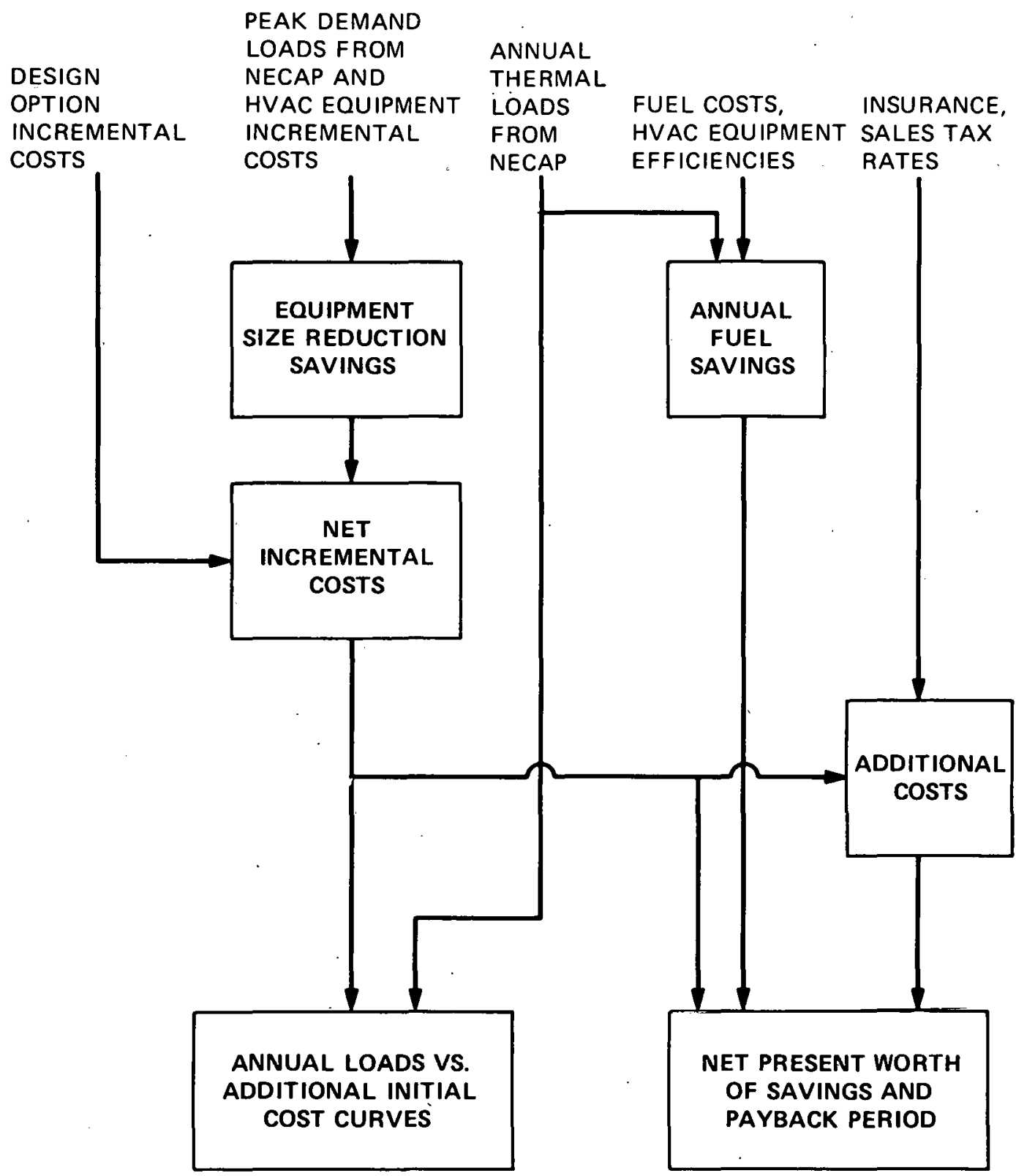

Figure 4. Economic analysis program flowchart. 
To determine the seasonal fuel consumption, all loads are assumed to be met (i.e., the seasonal useful heat supplied or removed is equivalent to the annual heating or cooling load, respectively). Equation (IV-1) is rearranged to yield

$$
\left[\begin{array}{l}
\text { Seasonal } \\
\text { fuel } \\
\text { consumption }
\end{array}\right]=\left[\begin{array}{l}
\text { Annual } \\
\text { heating/cooling } \\
\text { load }
\end{array}\right] \div\left[\begin{array}{l}
\text { Seasonal fuel } \\
\text { utilization } \\
\text { efficiency }
\end{array}\right]
$$

Annual fuel savings are due to the reduced energy consumption of energy-efficient design. The following equation gives the dollar savings for a given design change, $\mathrm{N}$.

$$
\left[\begin{array}{l}
\text { Annual } \\
\text { fuel bill } \\
\text { savings }
\end{array}\right]=\left[\begin{array}{l}
E_{1}-E_{N} \\
(M B T U)
\end{array}\right] \cdot\left[\begin{array}{l}
\text { Fuel } \\
\text { costs } \\
(\$ / M B T U)
\end{array}\right] \div\left[\begin{array}{l}
\text { Seasonal fuel } \\
\text { utilization } \\
\text { efficiency }
\end{array}\right]
$$

where

$$
\begin{aligned}
& E_{1}=\text { baseline configuration energy consumption, and } \\
& E_{N}=\text { energy consumption for design option, } N \text {. }
\end{aligned}
$$

Additional costs incurred for each design option include the material and labor costs for the additional design itcms plus the resulting increases in state sales tax and insurance premium.

A net present worth (NPW) analysis is used to compare the costeffectiveness of different design options. The objective is to maximize the net present worth of savings, which is the difference between the present worths of savings and costs. Future constant-valued savings and costs are discounted to the present by the following equations: 


$$
\begin{aligned}
& {\left[\begin{array}{l}
\text { Present worth of } \\
\text { savings/costs }
\end{array}\right]=\left[\begin{array}{l}
\text { Annual } \\
\text { savings/ } \\
\text { costs }
\end{array}\right] \cdot\left[\begin{array}{l}
\text { Uniform-series } \\
\text { present worth } \\
\text { factor (USPW) }
\end{array}\right]} \\
& \text { USPW }=\frac{(1+i)^{n}-1}{i(1+i)^{n}}
\end{aligned}
$$

where

$i=$ annual real interest rate, and

$\mathrm{n}=$ investment lifetime (years).

The net present worth of savings (NPW) is

$N P W=$ PWAFB - PWAIP - CØPT $(1+T X R)$

where

$\mathrm{PWAFB}^{\circ}=$ present worth of annual fuel bill reduction $(\$)$,

PWAIP $=$ present worth of additional annual insurance premium $(\$)$,

$\mathrm{C} \emptyset \mathrm{PT}=$ additional design option $\operatorname{cost}(\$)$, and

TXR = sales tax rate

$\mathrm{PWAFB}=[(\mathrm{SAV} / \mathrm{EFF}) \cdot \mathrm{FC}] \cdot \mathrm{USPW}$

where

$$
\begin{aligned}
& \mathrm{SAV}=\text { energy savings (MBTU), } \\
& \mathrm{EFF}=\text { seasonal fuel utilization efficiency, and } \\
& F C=\text { fuel costs }(\$ / M B T U) \\
& \text { PWAIP }=\mathrm{C} \emptyset \mathrm{PT} \cdot \mathrm{PRR} \cdot \mathrm{USPW}
\end{aligned}
$$

where

$$
\mathrm{PRR}=\text { insurance premium rate } .
$$


From Equation (IV-7) the NPW for each option can be calculated. The maximum value among the various combinations of options for any location is the optimum.

Because the inputs used in the Economic Analysis Program can vary over a wide range (see Table 7 , page 22), it is necessary to investigate their effect on the final result. The values in the range column of Table 7 are divided into two extremes - those that encourage additional investment and those that discourage the same. Values of each extreme are run independently to determine the maximum effects on the results. Other runs are made eliminating the variables which cause negligible changes, so that the important factors are discovered.

A complete listing of the Economic Analysis Program is contained in Appendix B. 


\section{RESULTS AND INTERPRETATION}

\section{Engineering Analysis}

Many NECAP runs were made for the Kansas City location to determine the order in which the different design features (listed in Section II) should be added to obtain maximum cost-effectiveness. To assist in this task multiple runs of the baseline configuration mobile home in Kansas City were made to determine the distributions of the annual heating gains and losses. The thermostat settings for the heating and cooling seasons were $72^{\circ} \mathrm{F}$ and $78^{\circ} \mathrm{F}$, respectively, with no night setback. The results of this initial NECAP analysis are shown in Figures 5 and 6 . Walls represent the major heat loss, and windows the largest heat gain. However, the cost-effectiveness of any option depends not only on its ability to reduce energy consumption, but also on the additional initial expense to the consumer (while assuming negligible maintenance costs). Therefore, by combining the results of many NECA.P runs and cost data rrum Table 4, page 12, the order for adding previously defined energy-efficient designs is determined. Since heating fuel bills dominate cooling in all but the mildest climates, the following order is based on heating only:*

1. baseline configuration

2. increase wall insulation to $2^{\prime \prime}$

3. increase ceiling insulation to $3.5^{\prime \prime}$

4. increase wall insulation to $3.5^{\prime \prime}$

*Each step is cumulative, i.e., the decision to proceed from one step to the next is based on benefits and costs relative to those incurred from previous steps. 
ORNL-DWG 78-4602

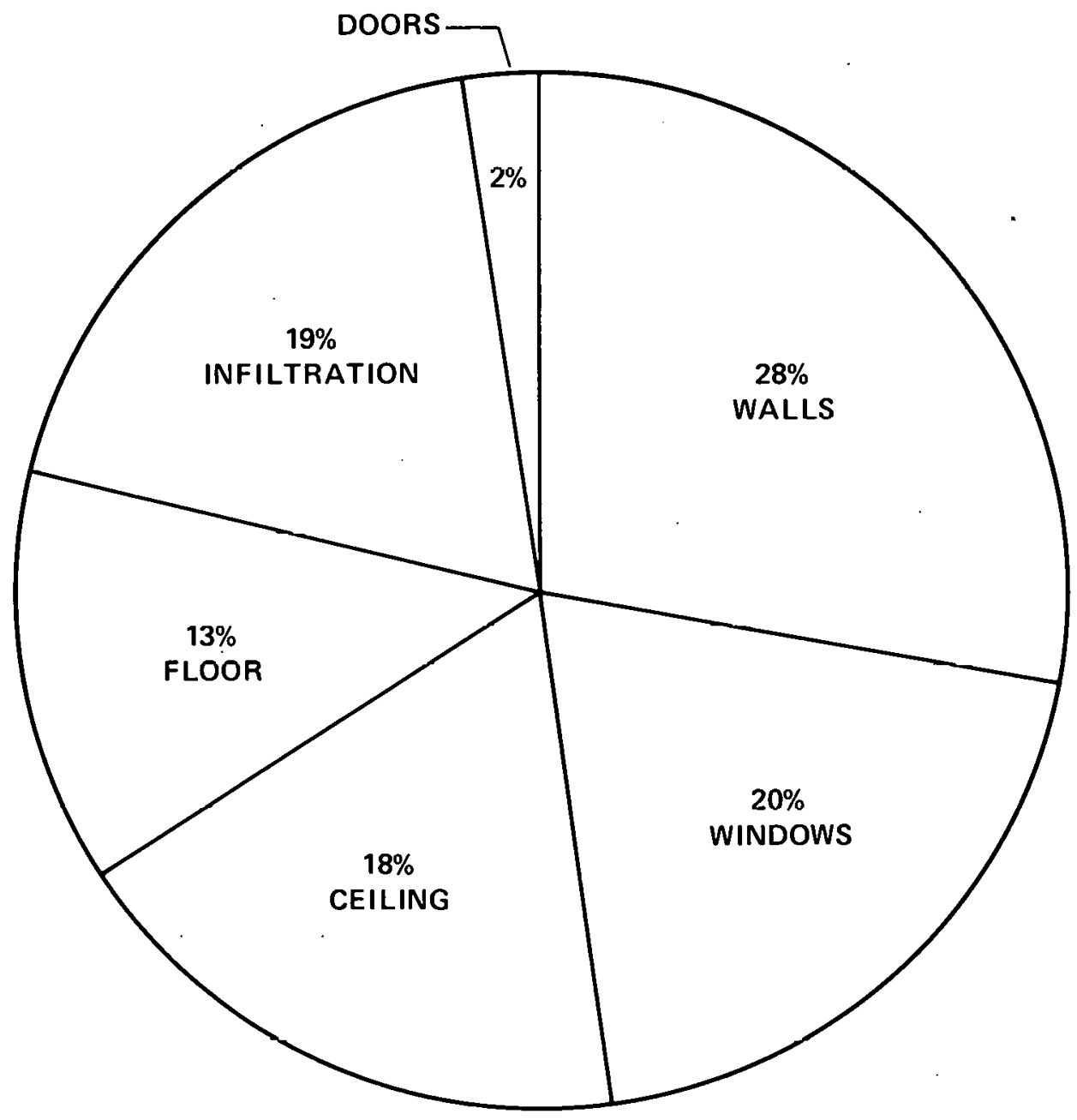

Figure 5. Distribution of heating season heat losses in a Kansas City mobile home - baseline configuration. Total annual heat loss is $85.3 \mathrm{MBtu}$. 


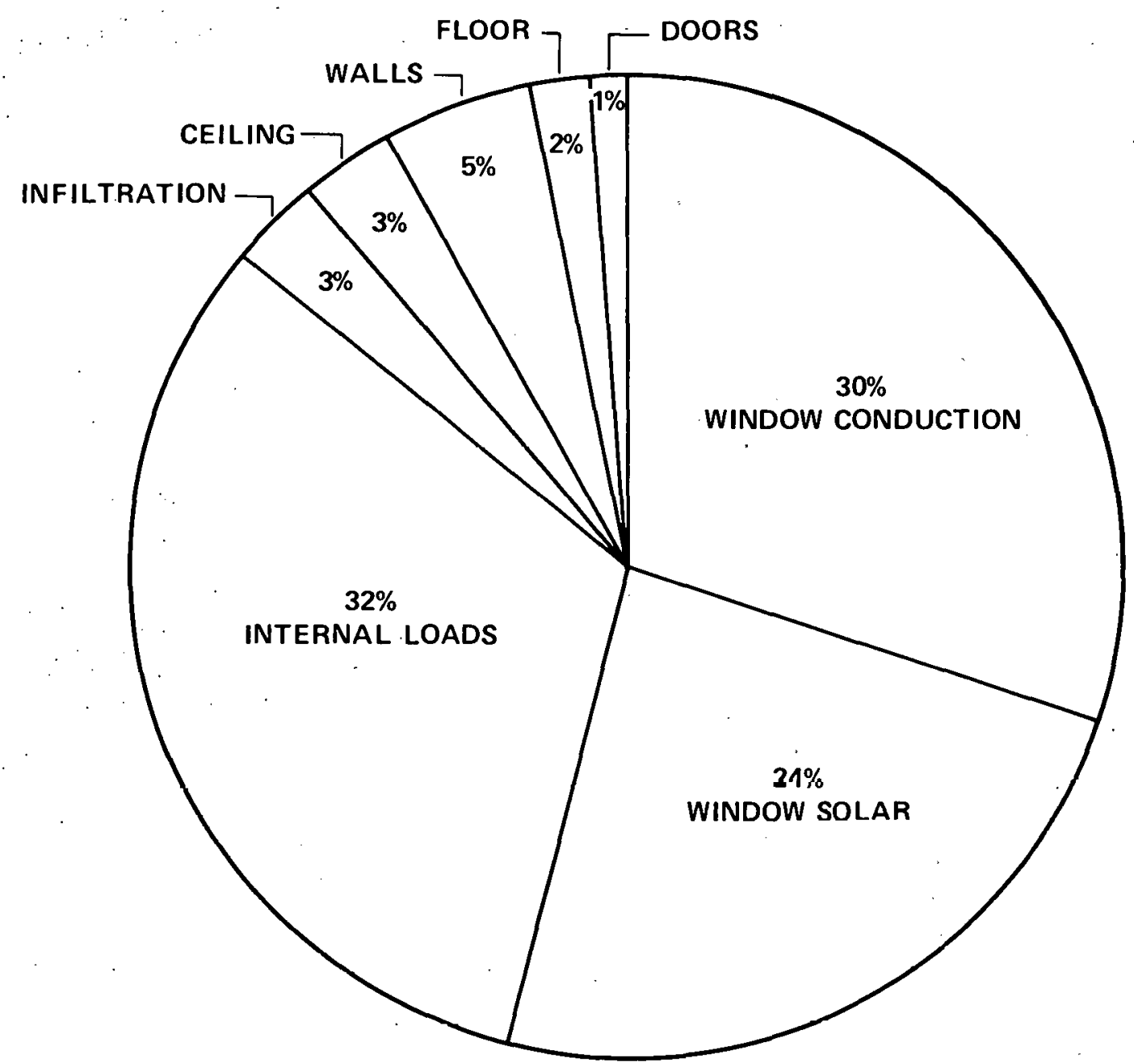

Figure 6. Distribution of cooling season heat gains in a Kansas City mobile home - baseline configuration. Total annual heat gain is 17.4 MBtu. 
5. orient mobile home (E-W)

6. increase floor insulation to $3.5^{\prime \prime}$

7. add storm windows

8. increase ceiling insulation to $6.0^{\prime \prime}$

9. increase floor insulation to $5.5^{\prime \prime}$

10. add insulated sheathing to walls

11. install underpinning around perimeter

12. install awnings on south-facing windows

This order remains basically unchanged for all locations. Because cooling dominates heating in Miami, another order was determined for this city.

1. baseline configuration

5. orient mobile home (E-W)

12. install awnings on south-facing windows

6. increase floor insulation to $3.5^{\prime \prime *}$

3. increase ceiling insulation to $3.5^{\prime \prime}$

7. install storm windows

11. instal1 underpinning

2. increase wall insulation to $2 "$

4. increase wall insulation to $3.5^{\prime \prime}$

8. increase ceiling insulation to $6.0^{\prime \prime}$

*Thc position of flnnr insulation ranked above ceiling insulation was an unexpected result and difficult to explain. However, since most mobile homes do not have underground walls or floors, ground temperature has a small influence on heat flow across the floor. Also, the roof absorptivity is low (0.26) and does reradiate energy to the sky at night. 
9. increase floor insulation to $5.5^{\prime \prime}$

10. add insulated sheathing to walls

As insulation is added to the walls, the infiltration is assumed to decrease ${ }^{3}$ (see Table A-5, Appendix A). This tends to lessen the value of insulation during the cooling season by reducing the beneficial effects of ventilation when outdoor temperatures are below the set point, $78^{\circ} \mathrm{F}$. For this reason the cooling equipment was allowed to operate only certain times of the year (Table 6, page 17). However, judicious use of window openings not assumed here could help alleviate this problem.

NECAP results for Kansas City are in Table 8 , using the heating-only order. Results for the remainder of the locations are in Appendix C, Tables $\mathrm{C}-1$ through $\mathrm{C}-9$. Table $\mathrm{C}-10$ contains results for Miami using the cooling-only ordering.*

A graph of baseline annual sensible heating and cooling loads versus heating and cooling degree days, respectively, for each of the nine cities is shnwn in Figure 7. The cole fur the ldentification of the location initials in Figure 7 and others to follow is in Table 6. The approximately linear relationships indicate that heating and cooling degree days are meaningful parameters in estimating annual loads. As the thermal integrity of the building improves, the slope of these curves will decrease. However, recent unpublished work by Petersen at the National Bureau of Standards indicates that it is necessary to decrease the reference temperature from $65^{\circ} \mathrm{F}$ to achieve a good curve fit. Btu.

*Note MBtu in these tables and others to follow equals one million 
TABLE 8

NECAP LOAD CALCULATION RESULTS - KANSAS CITY

\begin{tabular}{|c|c|c|c|c|c|c|c|}
\hline \multirow{2}{*}{$\begin{array}{l}\text { Design } \\
\text { Option }\end{array}$} & \multirow{2}{*}{$\begin{array}{l}\text { Additional } \\
\text { Feature }\end{array}$} & \multicolumn{2}{|c|}{ Annual Loads (MBtu) } & \multicolumn{2}{|c|}{$\begin{array}{l}\text { Peak Demlinds } \\
(\mathrm{kBtu} / \mathrm{hr})\end{array}$} & \multicolumn{2}{|c|}{$\begin{array}{l}\text { Additiondal Initiall } \\
\text { Cost }(1975-\$)^{*}\end{array}$} \\
\hline & & Heating & Cooling & Heating & Cooling & Heat Only & Heat $+\mathrm{A} / \mathrm{C}$ \\
\hline 1 & Baseline & 85.3 & 17.4 & 57.3 & 26.4 & 0. & 0. \\
\hline 2 & $2^{\prime \prime}$ wall insulation & 77.8 & 17.4 & 52.9 & 24.9 & 24 . & 0 . \\
\hline 3 & 3-1/2" ceiling ins. & 70.3 & 17.0 & 49.1 & 23.7 & 91. & 47. \\
\hline 4 & 3-1/2" wall ins. & 65.6 & 16.8 & 46.6 & 22.8 & 137. & 80. \\
\hline 5 & E-W orientation & 60.2 & 15.6 & 41.4 & 19.1 & 197. & 80. \\
\hline 6 & 3-1/2" floor ins. & 54.0 & 15.2 & 38.0 & 18.0 & 276 . & 141 \\
\hline 7 & Storm windows & 43.0 & 14.7 & 31.9 & 16.2 & 524 . & 360. \\
\hline 8 & 6" ceiling ins. & 40.5 & 14.6 & 30.6 & 15.7 & 596. & 425. \\
\hline 9 & $5-1 / 2^{\prime \prime}$ floor ins. & 38.9 & 14.6 & 29.8 & 15.5 & 663. & 489. \\
\hline 10 & Insulated sheath." & 36.5 & 14.6 & 28.1 & 15.0 & 823. & 641. \\
\hline 11 & Underpinning & 34.1 & 13.4 & 23.7 & 14.1 & 1249 & 1067. \\
\hline 12 & Awnings & 35.5 & 12.2 & 23.7 & 13.5 & 1474 & 1282 \\
\hline
\end{tabular}

*These figures include labor and material costs less savings due to HVAC equipment size reductions. 


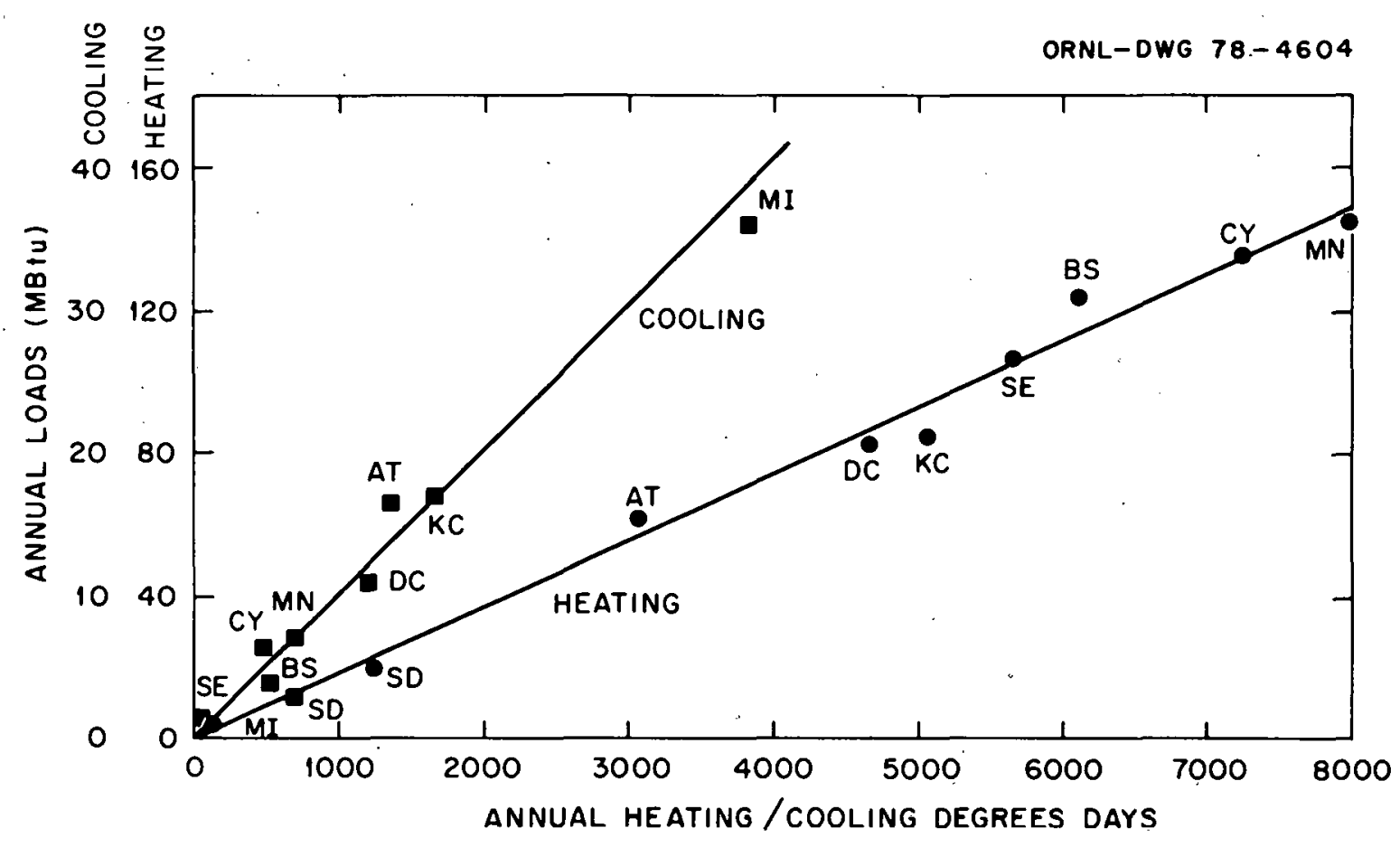

Figure 7. Regional variation in annual baseline configuration loads. 
The equations that define these relationships for the baseline configuration in Figure 7 are:

$$
\begin{aligned}
& \operatorname{AHL}(1) \simeq 0.0187 \cdot \mathrm{HDD} \\
& \operatorname{ACL}(1) \simeq 0.0103 \cdot \mathrm{CDD}
\end{aligned}
$$

where

$$
\begin{aligned}
& \operatorname{AHL}(1)=\text { annual heating load for baseline configuration (MBtu), } \\
& \text { HDD = annual number of heating degree days, } \\
& \operatorname{ACL}(1)=\text { annual sensible cooling load for baseline (MBtu), and } \\
& \mathrm{CDD} \quad=\text { annual number of cooling degree days. }
\end{aligned}
$$

Note that the heating and cooling loads in Figure 7 are sensible ones only. This causes no problem with heating since residential electric and gas furnaces essentially provide only sensible heating. However, cooling equipment operation is more complex because it handles both loads to meet the comfort requirements of the occupants. This complexity plus the variation in the percentage of latent to the total load across the United States ( 5 to $20 \%$ ) cause the cooling requirements to be much less predictable than for heating. The consequence is slightly conservative analysis results. However, the effects of this approximation are minimized by the use of marginal analysis. In this method errors in the absolute values are significantly reduced by presenting the results as relative quantities. 
Economic Analysis

Normalizing the loads to the baseline to represent the annual energy requirement (in percent) of the baseline and plotting them as a function of additional initial cost, generates the load versus cost curve for Kansas City shown in Figure 8 (a portion of the Economic Analysis Program output). Results for the remainder of the locations are in Appendix C, Figures C-1 through C-9. The curves are used for electric resistance or gas heating only. These figures show that the order of the options varies only slightly among the different locations and does not affect the shape of the curve (which demonstrate the law of diminishing marginal returns). Because the curve represents the envelope (most cost-effective designs), only a few well-spaced points are needed to define the curve shape. For Miami, Figure C-10 contains both heating and cooling load versus additional costs relationships, since cooling is a dominant factor there. The cooling only curve uses the different order for additions, as discussed earlier.* These curves also show the approximate positions of past and present mobile home thermal standards. Calculations used to locate these points are in Appendix D, Figures D-1 through D-8, and the results are summarized in Table D-1.

There are commercially available mobile homes with virtually all of the various design options in much of the United States. Some large manufacturers offer close to maximum levels of insulation (3-1/2"

*Awnings were not sized for optimum savings, but are representative of those available to consumers as off-the shelf items. In general these awnings provided an excess amount of shading so that heating season use resulted in increased energy consumption. 


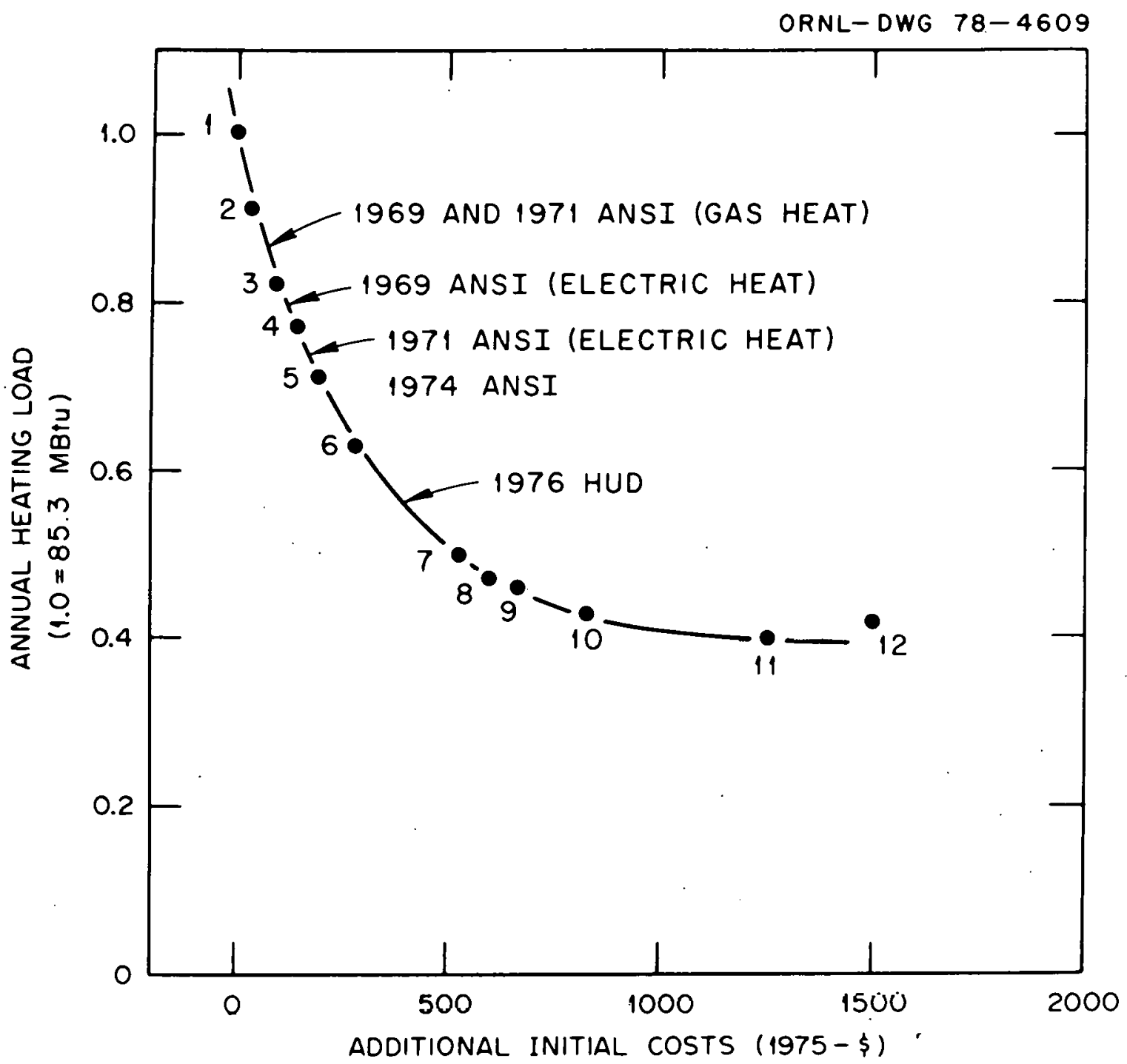

Figure 8. Load/cost relationship - Kansas City. 
fiberglass batt in walls, 6" fiberglass batt in ceiling and $3-1 / 2$ " batt in floor) as standard. Others offer "extra" or "double" insulation options. However, the effectiveness of additional insulation is sometimes diminished by poor installation and compression (e.g., advertised "double-wall insulation" where 2-1/2" already exists in 3-1/2" cavity).

To determine how the load versus additional cost curves (Figures $\mathrm{C}-1$ through (-9) vary by location, two curve characteristics are investigated. The initial slope and terminal asymptote for each of the nine heating only curves are plotted versus annual heating degree days for each location in Figure 9. The initial slope is approximately a linear function of the number of heating degree days:

$$
\mathrm{K} \simeq 4.50 \mathrm{E}-5 \cdot \mathrm{HDD}
$$

where

$\mathrm{K}$ is MBtu saved per additional dollar invested per HDD.

Therefore, the savings per additional dollar invested are greater and the design options are likely to be more cost-effective for locations in cold climates.

The asymptote characteristic, $\mathrm{T}_{\infty}$, is approximated by two linear functions.

$$
\begin{aligned}
\mathrm{T}_{\infty} & \simeq 0.35 & (\mathrm{HDD} \geq 3600) \\
& \simeq 0.05+8.33 \mathrm{E}-5 \cdot \mathrm{HDD} & (\mathrm{HDD}<3600)
\end{aligned}
$$




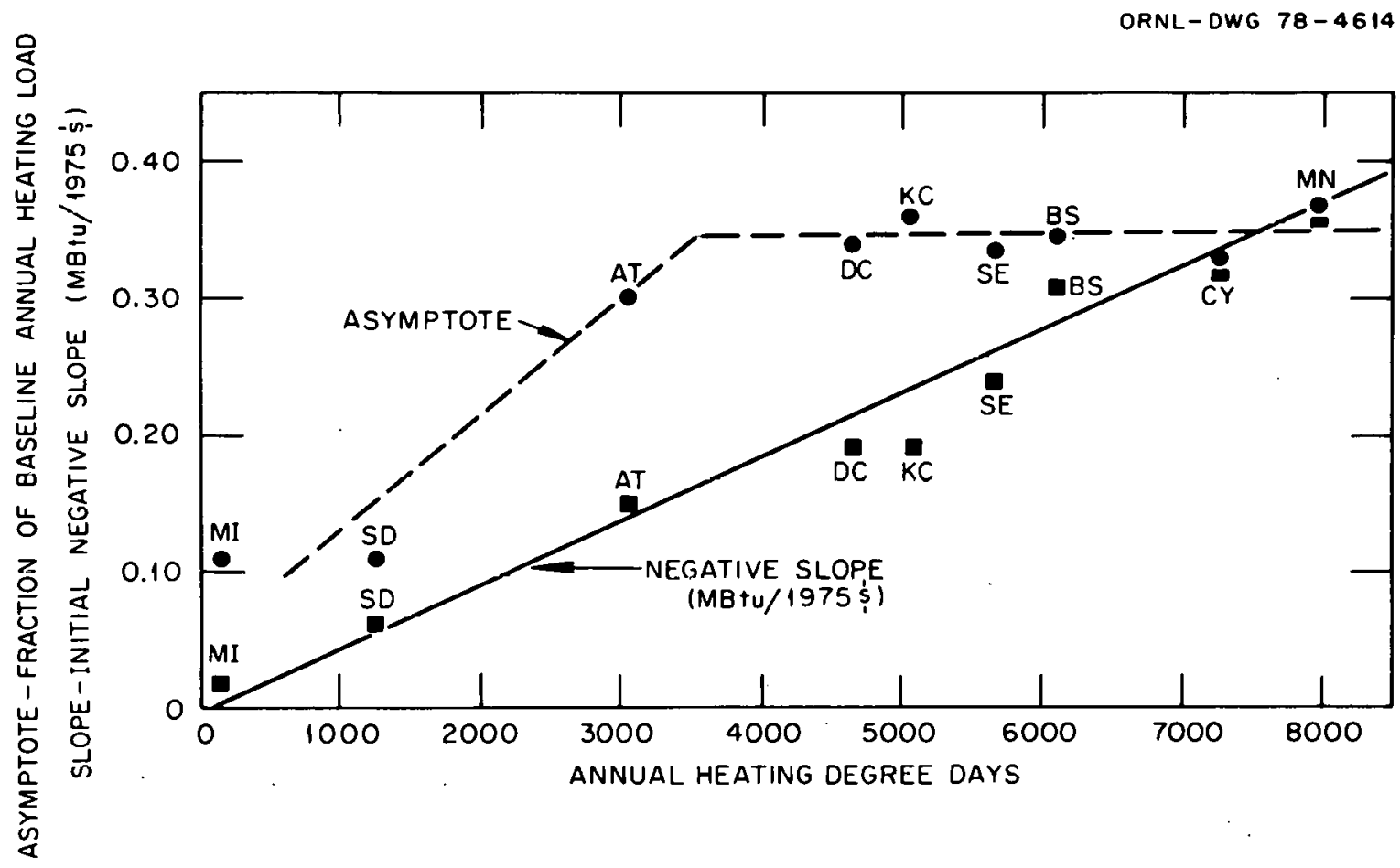

Figure 9. Regional variation in heating load versus cost curve parameters. 
For locations with mild winters the range of inside-outside temperature differences is small compared to those in colder climates. Therefore, any particular design change affects a larger percentage of the whole heating season (and yields a lower $\mathrm{T}_{\infty}$ value).

Figure 10 describes the relationship between annual heating load and annual cooling load for Kansas City. Results for the other locations are in Appendix C, Figures $\mathrm{C}-10$ through $\mathrm{C}-18$. The percent reduction in cooling load is much less than for heating. The reason for this is evident from Figures 5 and 6, pages 29 and 30 . Thirty percent of the cooling load is due to internal heat generation which is not affected by any of the design options. In fact, design options that increase the resistance to heat flow can cause an increase in cooling loads during mild summer weather by inhibiting the flow of heat from internal loads. In winter, however, any resistance to heat flow is beneficial, since internal loads decrease the heating requirements.

To investigate the regional variation of the heating versus cooling loads relationships, the ratio of the cooling load to the baseline load (at heating load $=0.40$ in Figures $\mathrm{C}-1$ through $\mathrm{C}-9$ ) is plotted for the number of heating degree days for the nine cities in Figure 11. Except for three locations the ratio remained in a narrow band from 0.75 to 0.91 . The three cities - San Diego, Boston, and Seattle - are al1 coastal cities with cool offshore waters and very low annual cooling loads. The low temperature offshore waters cause low inside-outside temperature differentials and cooling breezes during the summer which make energy conservation measures that offer resistance to heat flow ineffective. 


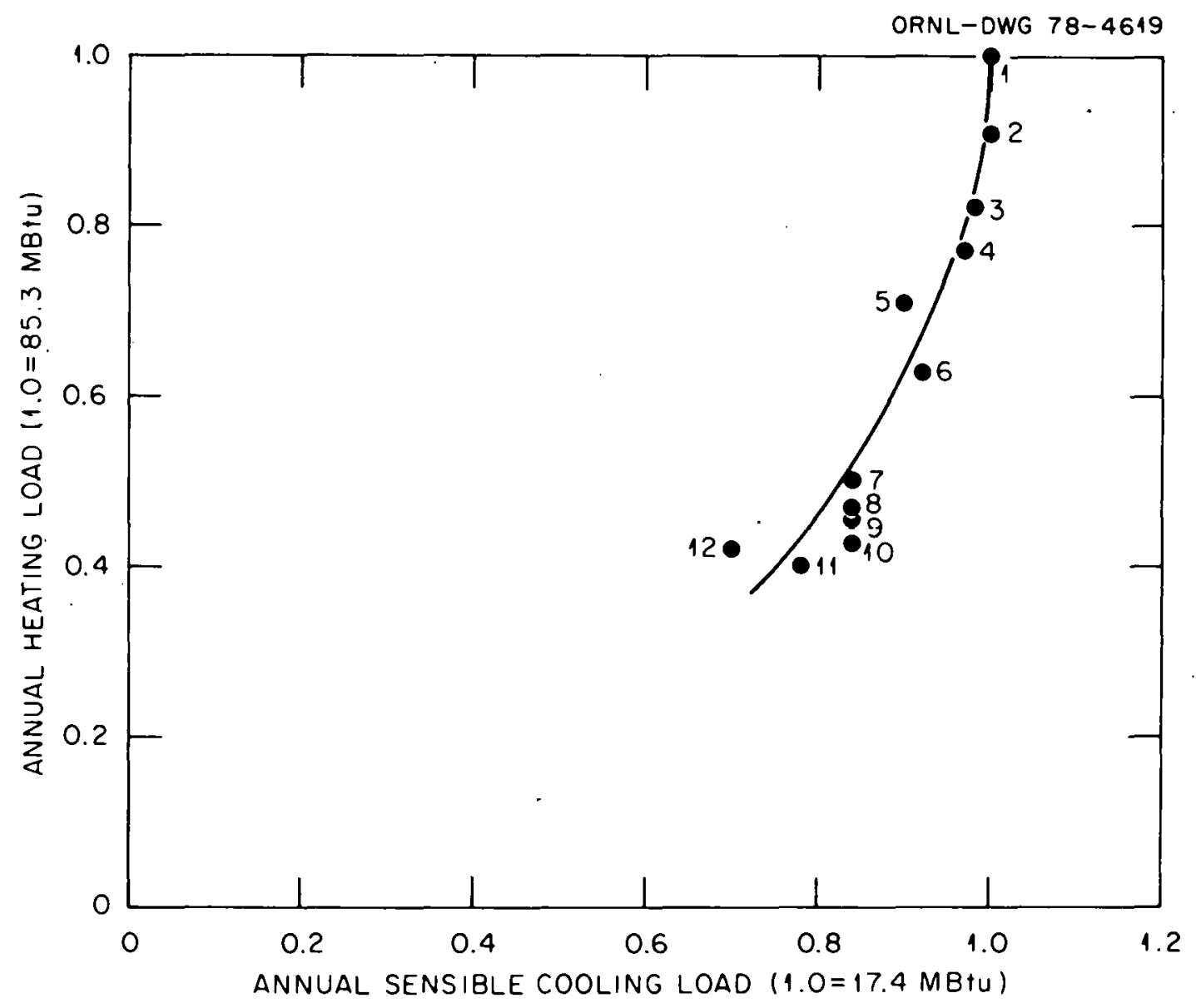

Figure 10. Heating/cooling load relationship - Kansas City. 
ORNL-OWG 78-4624

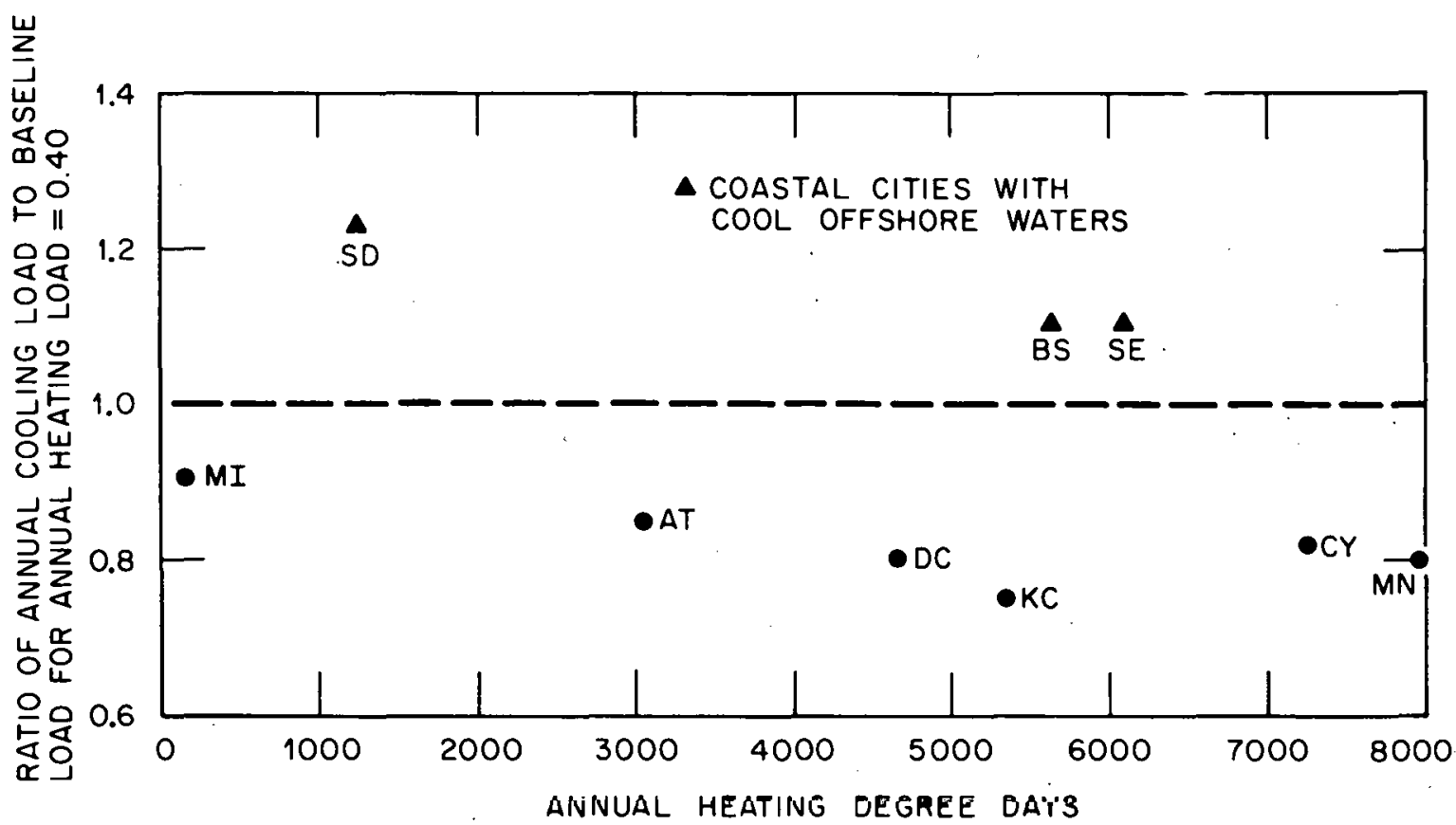

Figure 1l. Regional variation in annual heating versus cooling load relationships. 
The optimization analysis was performed for electric and gas heat, with and without air conditioning, at a $5 \%$ real interest rate. Results for Kansas City are in Table 9. Results for each of the nine cities, plus an additional one for Miami using the cooling-only order of design options (Table C-20) are in Appendix C, Tables C-11 through C-20. The results are represented by two columns labeled NPW (net present worth of savings) and PB (simple payback period). The optimal solution (i.e., largest NPW value) is underlined in each table. Some payback periods in Tables C-11 through $\mathrm{C}-20$ are negative. This occurs when the saving due to reduction in HVAC equipment size is greater than the additional initial investment required for the structure design option; thus there is no net cost for the option.

Figures 12 and 13 show the regional variation in the additional cost and primary energy saved relative to the baseline configuration for the optimal design selection. Also plotted on Figure 12 is the existing HUD thermal standard for mobile homes. The standard and the optimal compare favorably only in the mild climates (less than 3000 heating degree days for gas and less than 1000 for electric heating) with large differences elsewhere. The diagram shows the need for a standard based on fuel costs because of large differences in natural gas and electricity prices (as did the old ANSI mobile home standards ${ }^{7}$ ). Figure 14 shows the regional variation in primary energy savings for the optimal design compared to the HUD standard. The breakpoint (dashed line) in this figure represents the approximate location of the dividing line between Zone I and Zone II in the 1976 HUD mobile home standard. ${ }^{6}$ This 
TABLE 9

ECONOMIC ANALYSIS RESULTS - KANSAS CITY

\begin{tabular}{|c|c|c|c|c|c|c|c|c|}
\hline \multirow[b]{3}{*}{$\begin{array}{l}\text { Design } \\
\text { Option }\end{array}$} & \multicolumn{4}{|c|}{ Natural Gäs Heating } & \multicolumn{4}{|c|}{ Electric or LP Heating } \\
\hline & \multicolumn{2}{|c|}{ No $A / C^{*}$} & \multicolumn{2}{|c|}{ With $\mathrm{A} / \mathrm{C}^{*}$} & \multicolumn{2}{|c|}{ No $A / C^{*}$} & \multicolumn{2}{|c|}{ With $A / C^{*}$} \\
\hline & $\begin{array}{l}N P W^{* *} \\
(1975-\$)\end{array}$ & $\begin{array}{c}\mathrm{PB}^{* \star *} \\
\text { (years) }\end{array}$ & $\begin{array}{l}N P W^{* *} \\
(1975-\$)\end{array}$ & $\begin{array}{c}\mathrm{PB}^{* * *} \\
\text { (years) }\end{array}$ & $\begin{array}{c}N P W^{* *} \\
(1975-\$)\end{array}$ & $\begin{array}{c}\mathrm{PB}^{\star * *} \\
\text { (years) }\end{array}$ & $\begin{array}{l}\text { NPW** } \\
(1975-\$)\end{array}$ & $\begin{array}{c}\mathrm{PB}^{* * *} \\
\text { (years) }\end{array}$ \\
\hline 1 & 0 & 0.0 & 0. & 0.0 & 0 & 0.0 & 0. & 0.0 \\
\hline 2 & 191. & 1.0 & 222 . & 0.0 & 636. & 0.3 & 665. & 0.0 \\
\hline 3 & 329. & 2.0 & 401. & 1.0 & 1219. & 0.6 & . 1289 & 0.3 \\
\hline 4 & 409 . & 2.3 & 507. & 1.2 & 1579 & 0.7 & 1675 & 0.4 \\
\hline 5 & 493. & 2.6 & 718. & 0.9 & 1985. & 0.8 & 2204 . & 0.3 \\
\hline 6 & 577. & 2.9 & 841. & 1.3 & 2438. & 0.9 & 2697. & 0.5 \\
\hline 7 & 589. & 4.3 & 912. & 2.6 & 3112 . & 1.3 & 3427. & 0.9 \\
\hline 8 & 571. & 4.6 & 908. & 2.9 & 3245 . & 1.4 & 3574 . & 1.0 \\
\hline 9 & 534. & 5.0 & 875. & 3.3 & 3305 & 1.5 & 3638. & 1.1 \\
\hline 10 & 403. & 6.0 & 755. & 4.2 & 3323. & 1.8 & 3666. & 1.4 \\
\hline 11 & -63 & 9.3 & 340. & 6.8 & 3018 & 2.7 & 3412 . & 2.2 \\
\hline 12 & -388 & 11.9 & 79. & 8.4 & 2620 & 3.3 & 3078 . & $2.7^{\circ}$ \\
\hline
\end{tabular}

${ }^{\star} \mathrm{A} / \mathrm{C}=$ air conditioning

$* *$ NPW $=$ net present worth of savings

$\star \star * \mathrm{~PB}=$ payback period 
ORNL-DWG $78-4625$

REAL INTEREST RATE = $5 \%$

FUEL COSTS: NATURAL GAS $\$ 2 / M B+U$, ELECTRIC $\$ 10 / M B+U$, LP $\$ 6 / M B+U$

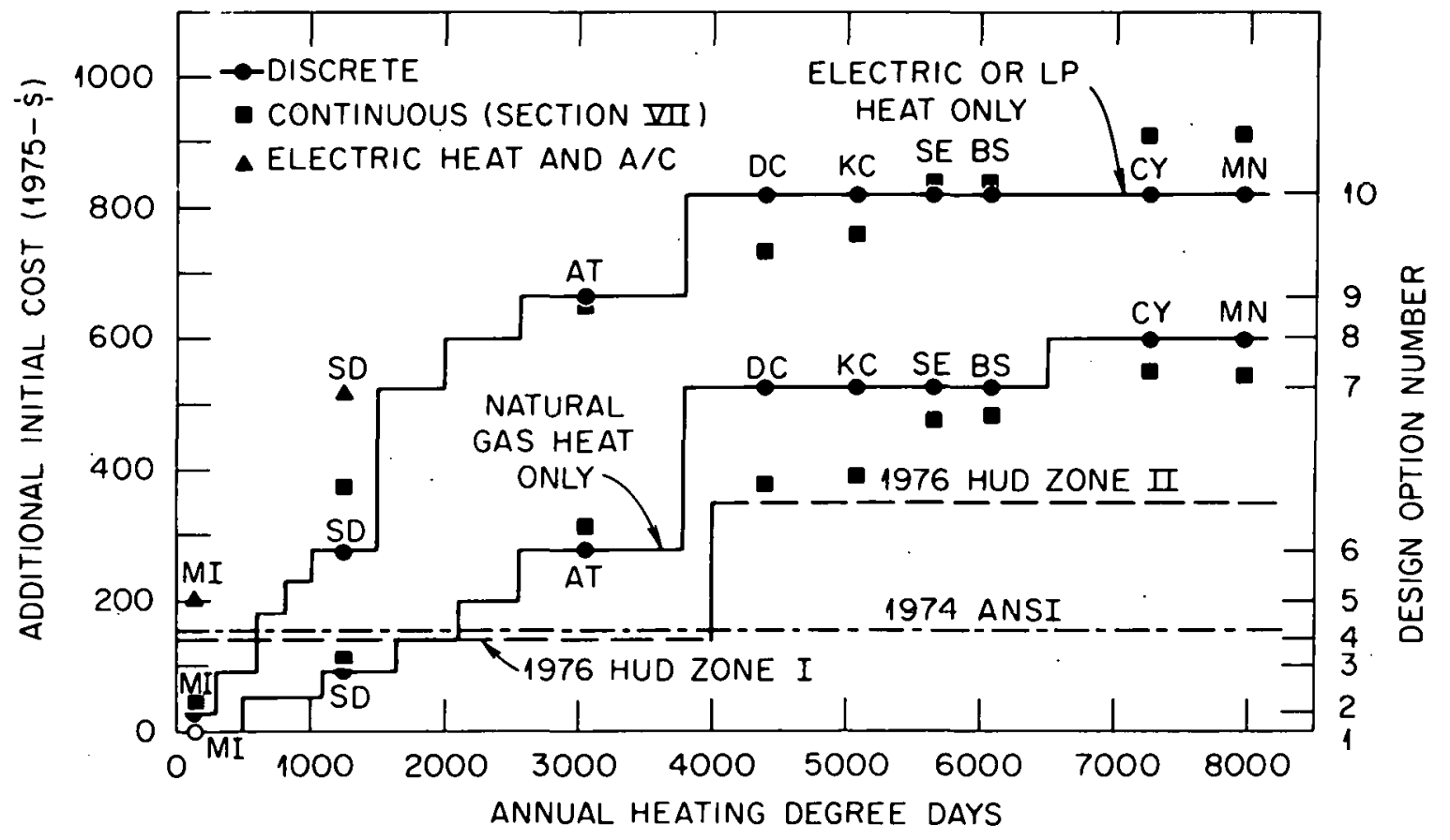

Figure 12. Reglonal variation in additional cost for optimal design selection. 


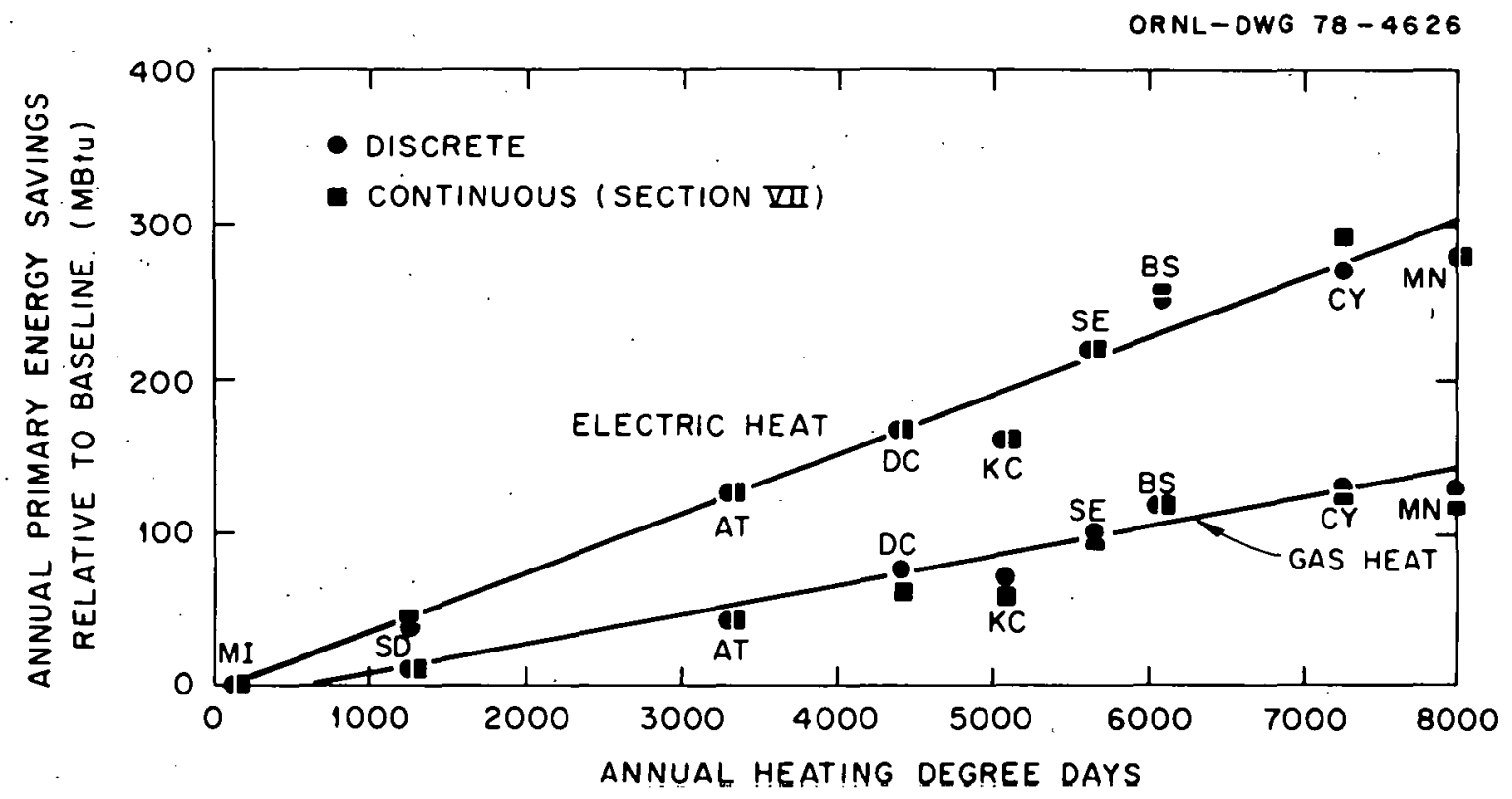

Figure 1.3. Regional variation in energy saved for optimal design selection. 


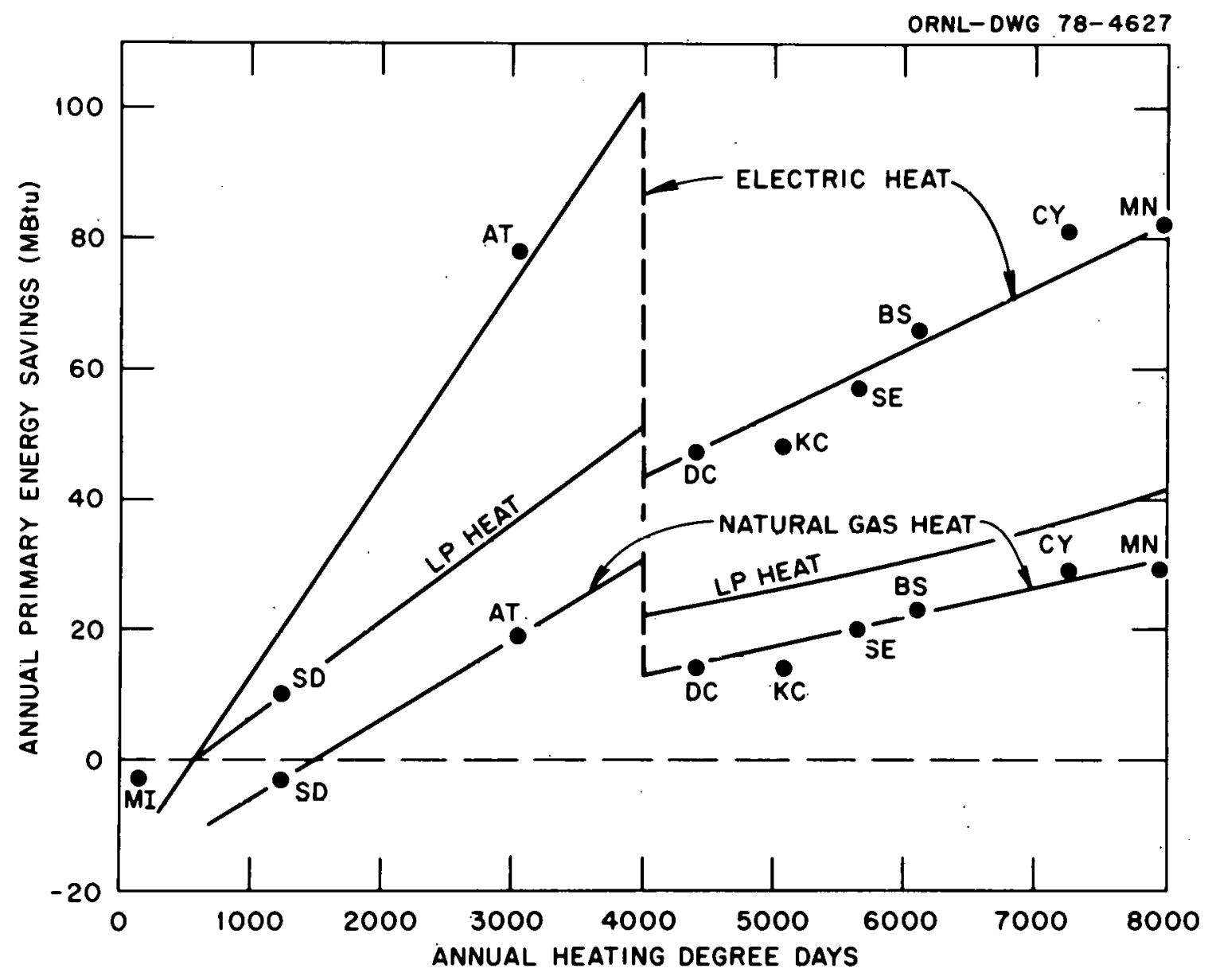

Figurc 14. Regiond variation in energy savings relative to 1976 HUD standard. 
dividing line delineates those areas that require storm windows ( $\sim>4000$ heating degree days, base $65^{\circ} \mathrm{F}$ ) from those that do not.

Approximately 300,000 new mobile homes are purchased each year. ${ }^{8}$ Fifty percent use gas, $40 \%$ electricity and the remainder use oil for heating. ${ }^{20}$ Using Figure 14, approximately 10.5 trillion Btu of primary energy would be saved in the first year using the optimal design (relative to the HUD standard). This amounts to $\$ 21$ million annually (using primary energy cost at $\$ 2 / \mathrm{MBtu}$ ) or about $\$ 70$ per new mobile home purchaser. Over a period of ten years 580 trillion Btu are saved (about $\$ 1.2$ billion).

Figures 15 and 16 show the regional variation in additional initial investment and fuel bill savings for the optimal design compared to the HUD standards. Additional investments for gas heated mobile homes are generally less than $\$ 200$ with paybacks of about four years. Although additional investments for electrically heated homes are as high as \$suu, paybacks are two to throo jrears.

\section{Sensitivity Analysis}

The only variable parameters that affect the annual load versus additional initial cost relationships are the material and labor cost indices. The indices are multiplied by the average additional costs for each design option and savings due to HVAC equipment size reduction to account for regional differences. Values $\pm 15 \%$ of the nominal were used as the variation in prices across the United States, ${ }^{14}$ and the results were plotted in Figure 17. Changes in the indices had little effect on the shape of the curve and, therefore, little effect on the optimal design selection. 


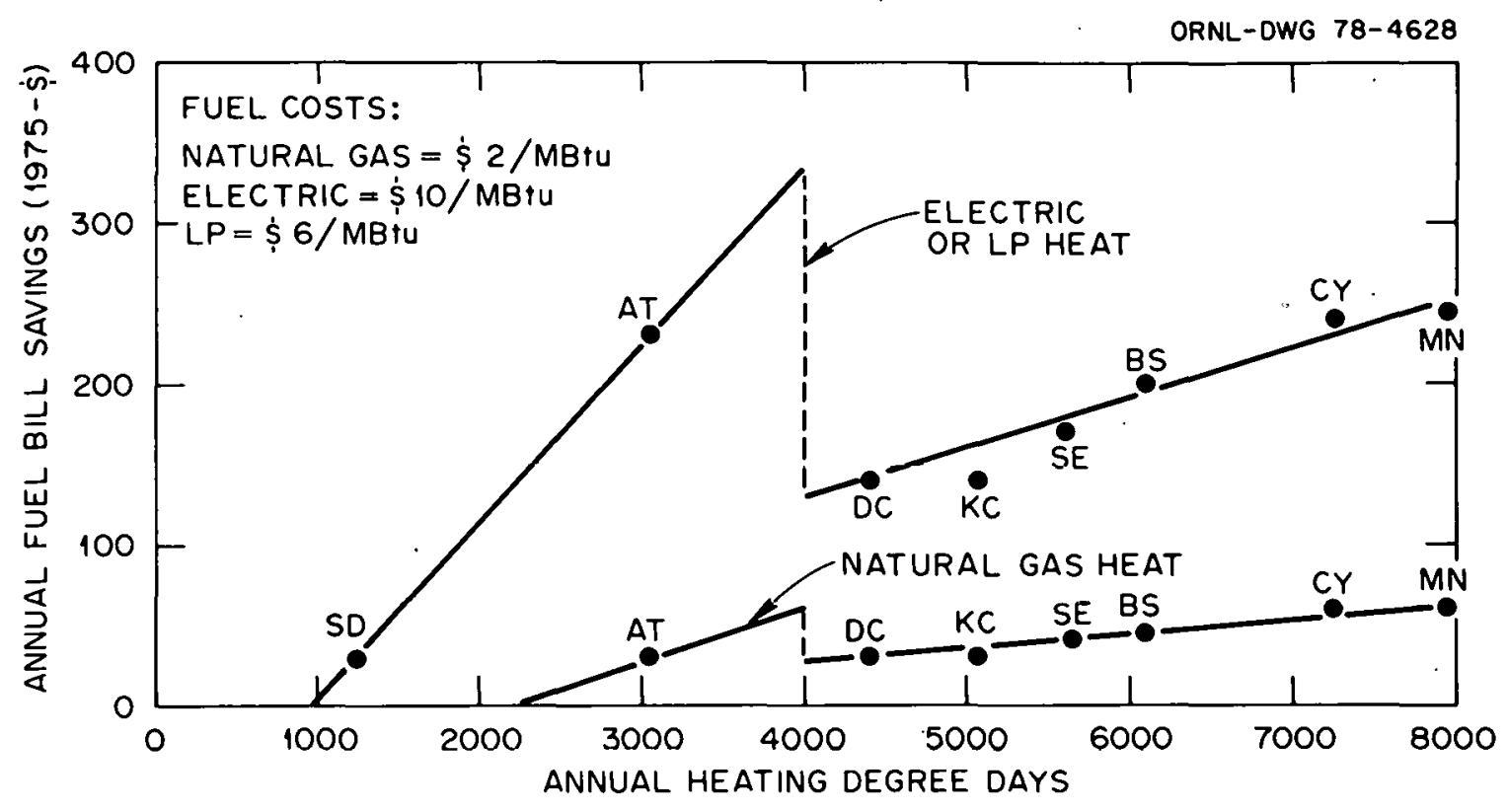

Figure 15. Regional variation in annual fuel bill savings for optimal design relative to 1976 HUD standard.

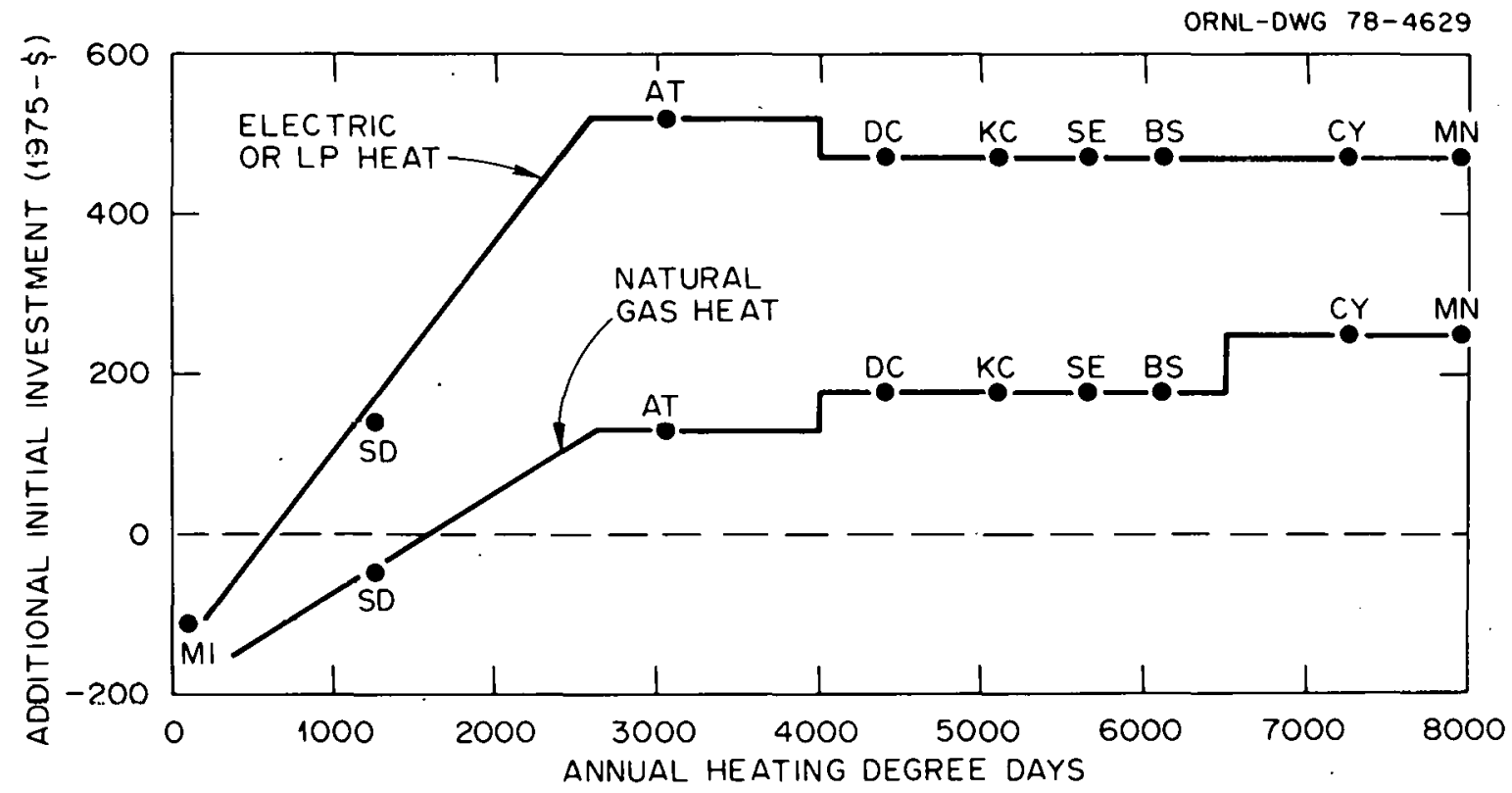

Figure 16. Regional variation in additional investment for optimal design relative to 1976 HUD standard. 


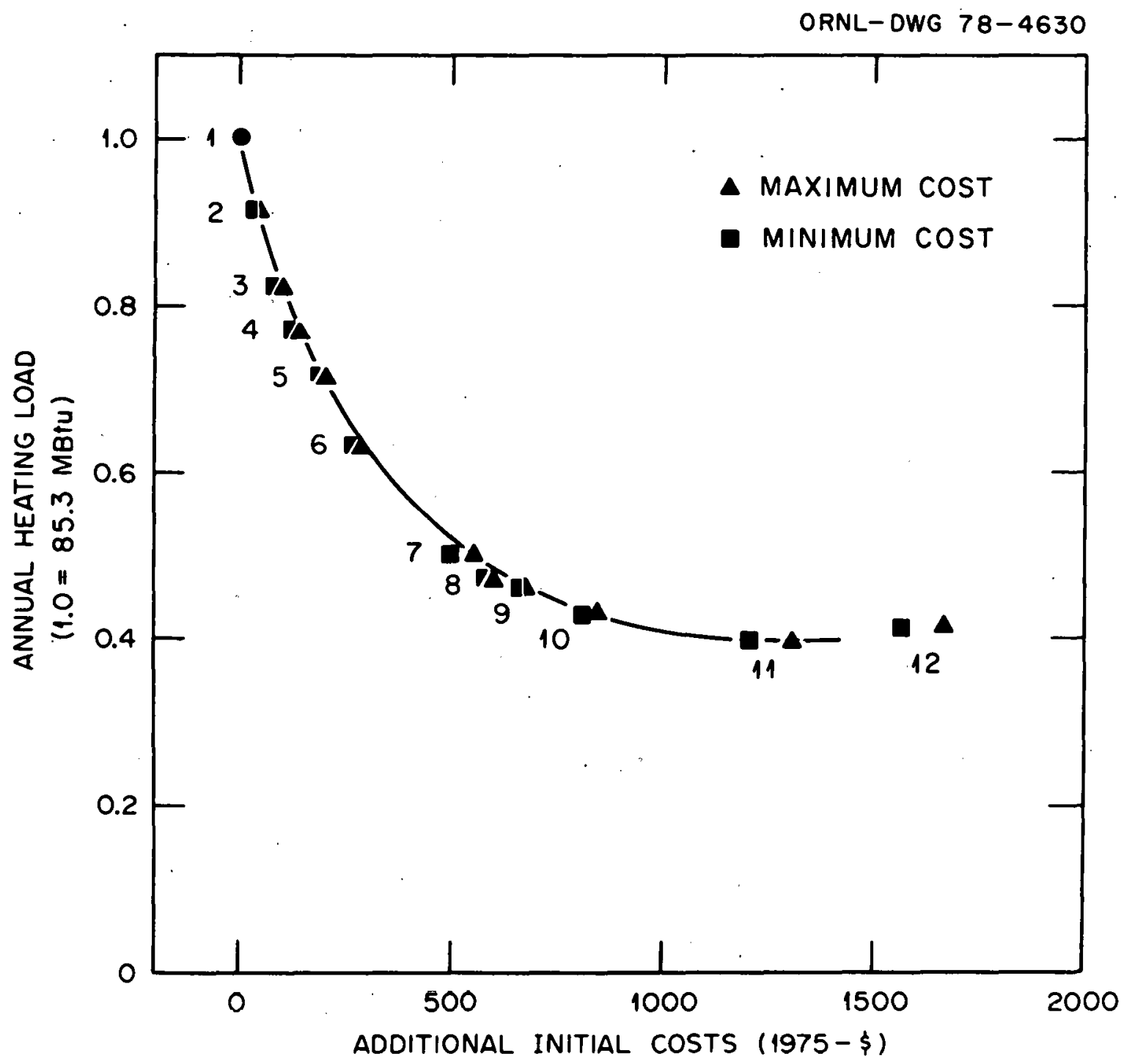

Figure 17. Effects of changes in labor and cost indices on. load versus cost relationships. 
The effects of changes in the variable parameters over the range of maximum and minimum values given in Table 7 , page 22 (with constant fuel price and interest rates) are shown in Tables 10 and 11 for natural gas and electric or LP heating, respèctively. For most locations the number of step changes is only one. The change in additional investment varied from zero to $\$ 289$. This is because of the considerable variation in additional costs for discrete steps in design change. For natural gas heating the larger additional investments are due to option \#7, the addition of storm windows. Therefore, the decision to add storm windows is marginal for natural gas heating for locations between 3000 and 5000 heating degree days (Washington, Atlanta, Kansas City, Seattle) for the nominal fuel prices and interest rates. It is interesting to note that in the HUD mobile home standard the dividing line for storm windows is at about 4000 heating degree days.

For electric and LP heating, the variations are smaller because option \#11, underpinning, is not justified under any of the conditions studied. The major contributor to the larger additional investments is \#10, insulated sheathing and storm windows in San Diego and in Miami (Cooling).

Because of the large incremental investment for such items as storm windows, underpinning, and insulated sheathing, there will always be significant uncertainty for optimal designs. Decisions in these areas should be andyzed on an individual basis and influenced by the prospects of rising fuel prices and changes in local interest rates. 
TABLE 10

EFFECTS OF CHANGES IN VARIABLE PARAMETERS ON OPTIMAL DESIGN SELECTION - NATURAL GAS HEAT*

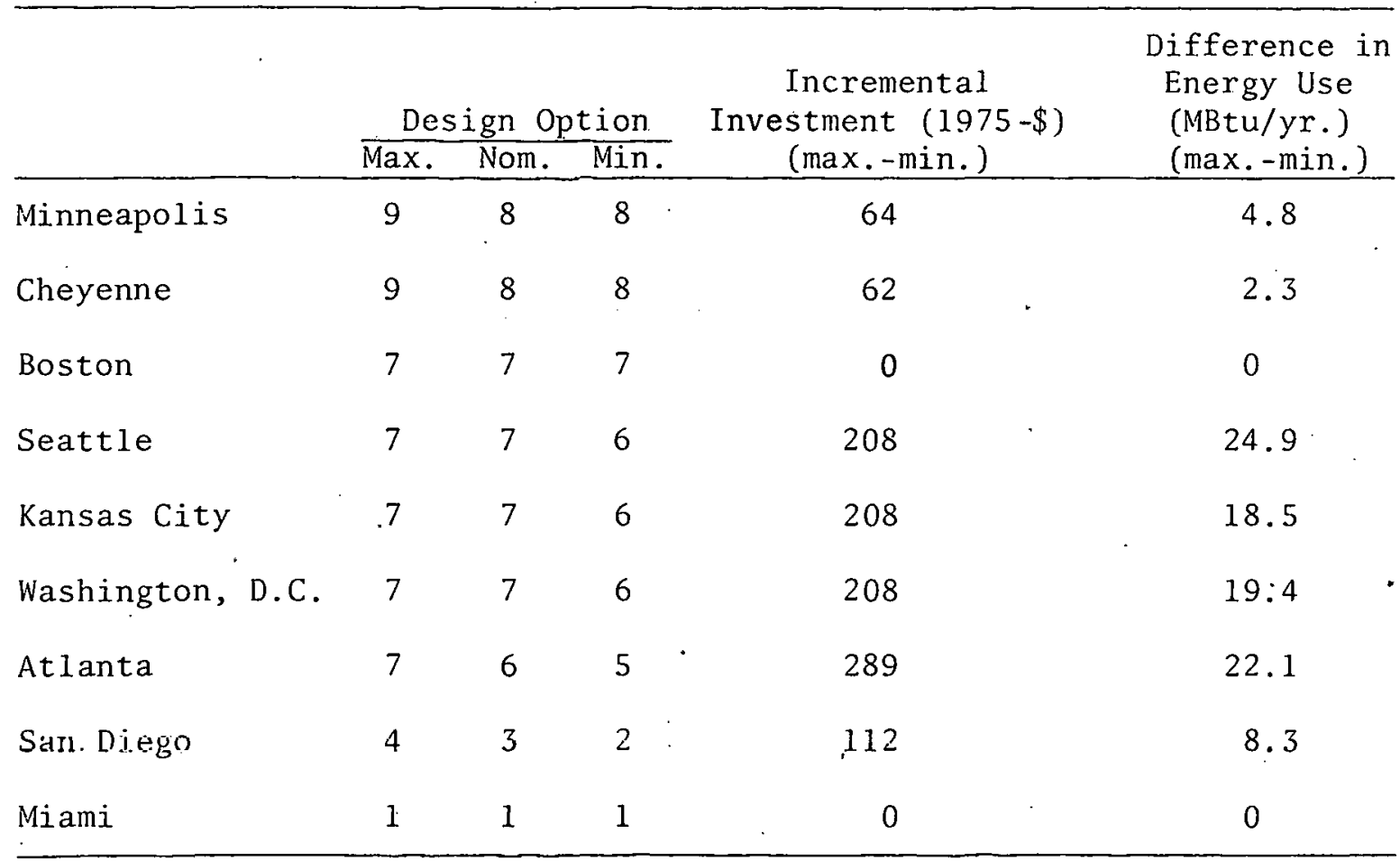

${ }^{*}$ Fuel price $=\$ 2.00 / \mathrm{MBtu} ;$ real interest rate $=5 \%$. 
TABLE 11

EFFECTS OF CHANGES IN VARIABLE PARAMETERS ON OPTIMAL

DESIGN SELECTION - ELECTRIC OR LP HEAT*

\begin{tabular}{|c|c|c|c|c|c|}
\hline & $\begin{array}{r}\text { Des } \\
\operatorname{Max} .\end{array}$ & $\begin{array}{l}\text { ign } 0_{1} \\
\text { Nom. }\end{array}$ & $\begin{array}{l}\text { tion } \\
\text { Min. }\end{array}$ & $\begin{array}{c}\text { Incremental } \\
\text { Investment (1975 \$) } \\
(\max .- \text { min. })\end{array}$ & $\begin{array}{l}\text { Difference in } \\
\text { Energy Use } \\
\text { (MBtu/yr.) } \\
\text { (max.-min.) }\end{array}$ \\
\hline Minneapolis & 10 & 1.0 & 10 & 0 & 0 \\
\hline Cheyenne & 10 & 10 & 10 & 0 & 0 \\
\hline Boston & 10 & 10 & 10 & 0 & 0 \\
\hline Seattle & 10 & 10 & 9 & 140 & 10.7 \\
\hline Kansas City & 10 & 10 & 9 & 142 & 8.5 \\
\hline Washington, D.C. & 10 & 10 & 9 & 141 & 8.3 \\
\hline Atlanta & 10 & 9 & 9 & 141 & 4.2 \\
\hline San Diego & 7 & 7 & 6 & 211 & 12.0 \\
\hline Miami & 2 & 2 & 1 & 25 & 1.9 \\
\hline Miami (Cooling)** & 6 & 5 & 3 & 176 & 3.6 \\
\hline
\end{tabular}

${ }^{*}$ Fuel price $=\$ 10 / \mathrm{MBtu}($ electricity), $\$ 6 / \mathrm{MBtu}$ (LP).

${ }^{*} \mathrm{~A} / \mathrm{C}$ only (see Table C-20, Appendix C, page 126). 
Using nominal values for parameters in Table 7 , page 22 , the effects of varying fuel price and interest rates are shown in Figure 18. The lines in the diagram define boundaries of the regions where a particular design option is optimum. As expected, low interest rates and high fuel prices encourage investment in energy-efficient designs. Also, the optimum values are more sensitive to fuel prices than to interest rates mostly because of the large change in fuel prices and small variation in real interest rates.

To use Figure 18 to examine the effects of increasing fuel prices, a uniform series equivalent of an escalating fuel price can be computed for time period $n$ and escalation rate $r$. The present worth of an annually recurring cost which is increasing at an annual rate of $r$, discounted at interest rate $i$ is:

$$
\begin{array}{ll}
\mathrm{PW}=\frac{1+\mathrm{r}}{1-\mathrm{r}}\left[1-\left(\frac{1+\mathrm{r}}{1+\mathrm{i}}\right)^{\mathrm{n}}\right] & (i \neq \mathrm{r}) \\
\mathrm{PW}=\mathrm{n} & (i=r)
\end{array}
$$

The uniform series with a present worth of $\$ 1$ (capital recovery) is:

$$
C R=i(1+i)^{n} /\left[(1+i)^{n}-1\right]
$$

Therefore, the uniform series with a present worth of an annually recurring cost increasing at an anual rate $\mathrm{r}$ is:

$$
\text { USCR }=\frac{i(1+r)(1+i)^{n}}{(i-r)}\left[1-\left(\frac{1+r}{1+i}\right)^{n}\right] /\left[(1+i)^{n}-1\right]
$$




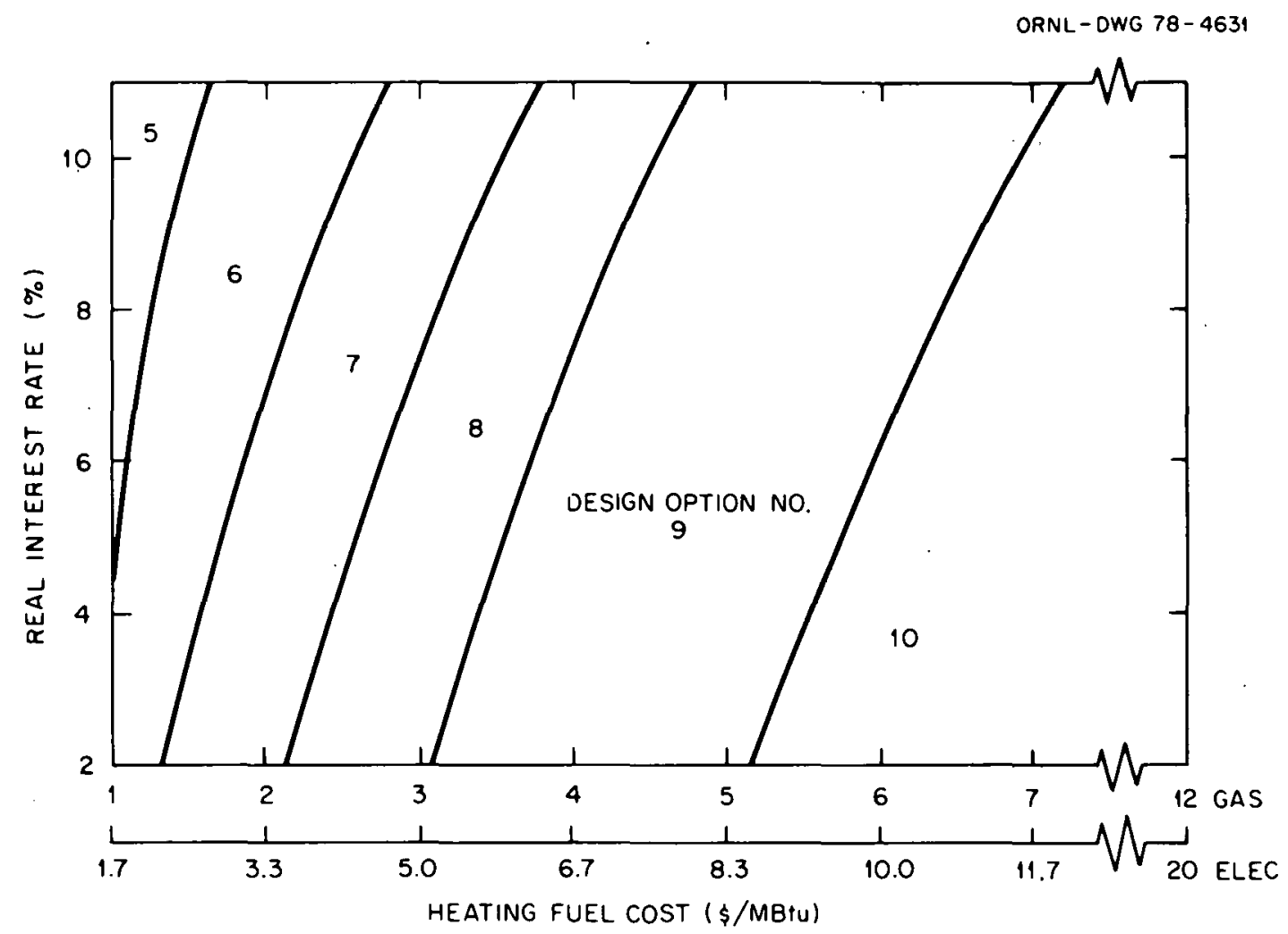

Figure 18. Optimal design selection sensitivity to changes in fuel costs and interest rates. 


$$
\text { USCR }=\frac{n i(1+i)^{n}}{(1+i)^{n}-1} \quad(i=r)
$$

The new constant-valued annual fuel price representing escalating fuel prices, EFP, is the product of the present fuel price, FP, and the USCR factor:

$$
\mathrm{EFP}=\mathrm{FP} \cdot \mathrm{USCR}
$$

The USCR factor varies little for the interest rates studied ( $2 \%$ to $11 \%$ ), therefore, the values for the factor from Equations (V-9) and (V-10) are listed in Table 12 for $i=5 \%$.

TABLE 12

FUEL PRICE ESCALATION FACTOR (USCR)

\begin{tabular}{cccc}
\hline $\begin{array}{c}\text { Real Fuel Price } \\
\text { Escalation Rate } \\
(\%)\end{array}$ & USCR & \multicolumn{2}{c}{$\begin{array}{c}\text { Constant-Valued Annual Fuel Gost } \\
\text { for Present Fuel Cost } \\
\text { Equivalent to }\end{array}$} \\
\hline 1 & 1.06 & 2.12 & 10.60 \\
2 & 1.12 & 2.24 & 11.20 \\
3 & 1.19 & 2.38 & 11.90 \\
4 & 1.27 & 2.54 & 12.70 \\
5 & 1.35 & 2.70 & 13.50 \\
\hline
\end{tabular}




\section{CONTINUOUS ANALYSIS}

To use the results of this study for policy analyses, as in Reference 2, continuous rather than discrete values are desirable for the annual energy consumption versus additional initial cost relationships. The shape of the curve that describes such relationships, Figure 19, is such that the first derivative is negative and the second is positive. A simple three-parameter equation satisfies the derivative constraints: ${ }^{2}$

$$
\mathrm{T} / \mathrm{T}_{\dot{0}}=\mathrm{T}_{\infty} / \mathrm{T}_{0}+\left(1-\mathrm{T}_{\infty} / \mathrm{T}_{0}\right)\left[\bar{\beta}-\frac{\beta}{\mathrm{\beta}+\mathrm{C}}\right]^{\alpha}
$$

where

$$
\begin{aligned}
\mathrm{T} & =\text { load requirement }(\mathrm{e} . \mathrm{g} ., \mathrm{MBtu} / \mathrm{y} \mathrm{r}), \\
\mathrm{C}= & \text { additional initial cost }(\mathrm{e} . \mathrm{g} ., 1975 \$), \text { and } \\
\mathrm{T}_{\infty}, \alpha, \beta= & \text { curve parameters. } \mathrm{T}_{\infty} \text { is the asymptotic limit and the } \\
& \text { slope at } \mathrm{C}=0 \text { is } \alpha\left(1-\mathrm{T}_{\infty}\right) / \beta .
\end{aligned}
$$

The subscript ( ) o designates the particular design reference. $T_{0}$ is the annual load requirement for the reference case. The curve parameters $\mathrm{T}_{\infty}, \alpha$, and $\beta$ are calculated for each of the Figures $\mathrm{C}-1$ through $\mathrm{C}-9$ (Appendix C) and listed in Table 13. The initial slope gives an indication of the rate of percent energy saved per dollar investment. Since it is a percent term, the number increases for milder climates. In Section V (see Figure 9, page 39) the initial slope was discussed in terms of actual MBtu/\$ which has the opposite effect (i.e., to decrease in milder climates. 


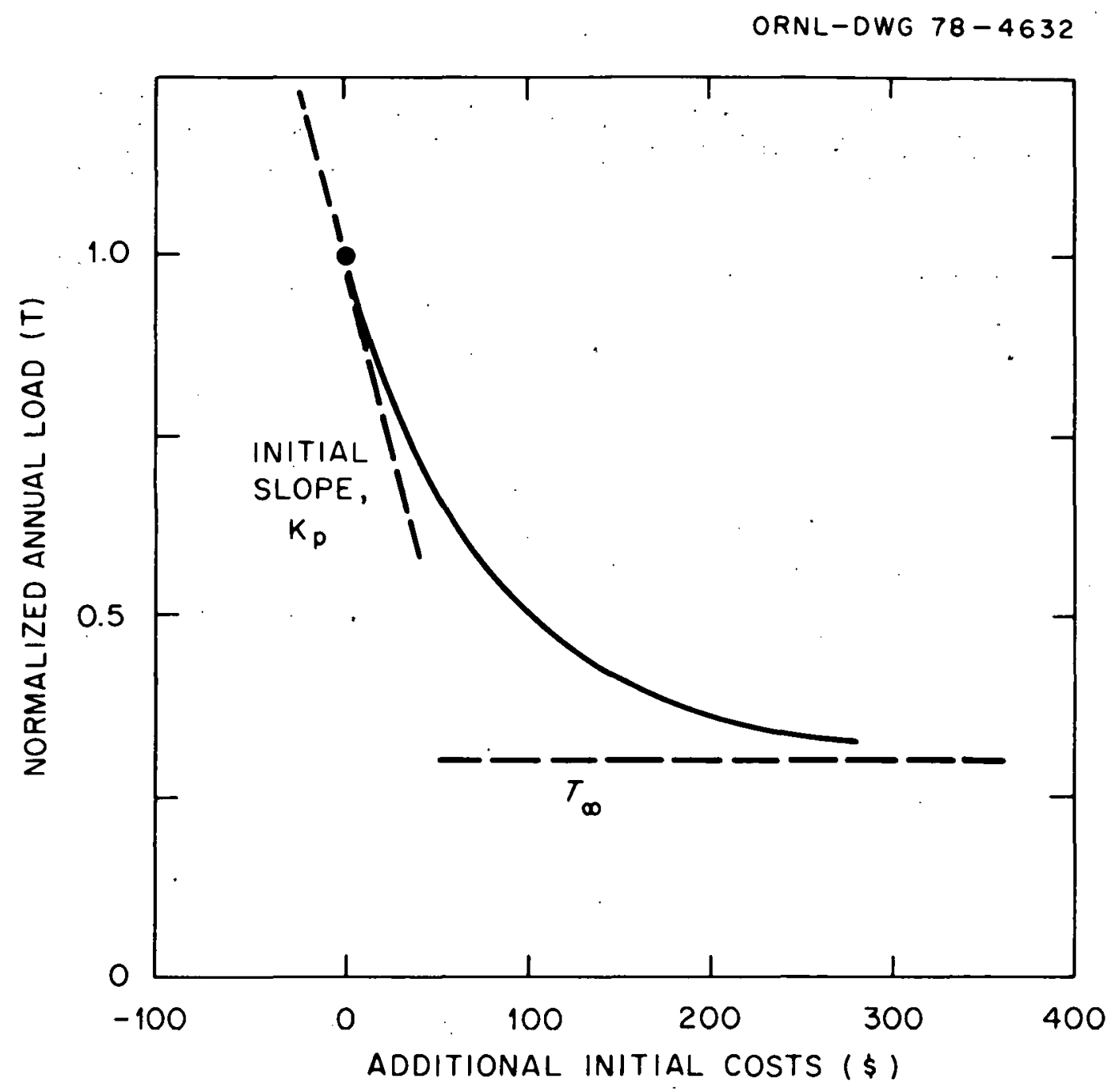

Figure 19. Characteristic load/cost relationship. 
TABLE 13

HEATING LOAD VERSUS COST CURVE PARAMETERS

\begin{tabular}{lccccc}
\hline & $\mathrm{T}_{\infty}$ & $\alpha$ & $\beta$ & $\begin{array}{r}\text { Initia) } \\
(\% \text { MBtu/1975 } \$ \text { (1) }\end{array}$ & $\begin{array}{r}\text { Baseline Annual } \\
\text { Load (MBtu) }\end{array}$ \\
\hline Minneapolis & 0.37 & 5 & 1,260 & 0.25 & 144.8 \\
Cheyenne & 0.34 & 4 & 1,070 & 0.25 & 136.2 \\
Boston & 0.34 & 4 & 910 & 0.29 & 124.0 \\
Seattle & 0.34 & 4 & 940 & 0.28 & 106.5 \\
Kansas City & 0.36 & 3.5 & 910 & 0.245 & 85.3 \\
Washington, D.C. & 0.34 & 3 & 720 & 0.275 & 83.3 \\
Atlanta & 0.30 & 3 & 750 & 0.28 & 63.1 \\
San Diego & 0.11 & 3 & 700 & 0.38 & 20.0 \\
Miami & 0.11 & 3 & 670 & 0.40 & 4.3 \\
Miami (Cooling) & 0.75 & 1.1 & 180 & 0.15 & 34.5 \\
\hline
\end{tabular}


The optimal design selection cost (that minimizes lifecycle costs) can now be completely described by an analytical expression as discussed in the following.

The group of equations which were discussed in Section IV that describe the NPW are rewritten here.

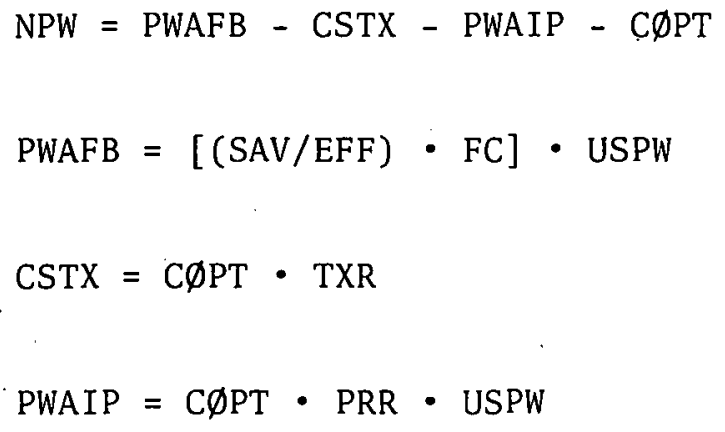

The following substitutions will be made to simplify the notation:

$$
\text { USPW }=F(i)
$$

where $i$ is the real interest rate (i.e., nominal less inflation).

$$
\begin{aligned}
& C \emptyset \mathrm{PT}=C \\
& S A V=S(C) \\
& k_{1}=E F F \\
& k_{2}=T X R \\
& k_{3}=\text { PRR }
\end{aligned}
$$

Substituting (VI-6) equations into (VI-5) yields

$$
N P W=S(C) \cdot F(i) \cdot F C / k_{1}-k_{2} C-k_{3} C \cdot F(i)-C
$$


and simplifying gives

$$
N P W=S(C) \cdot F(i) \cdot F C / k_{1}-\left(k_{2}+k_{3} F(i)+1\right) C
$$

The relationship between annual energy consumption and additional capital cost (see Figure 19, page 58) can be described using Equation (VI-1) for $\mathrm{T}_{0}$ normalized to unity

$$
T(C)=T_{\infty}+\left(1-T_{\infty}\right)\left[\frac{\beta}{\beta+C}\right]^{\alpha}
$$

The savings due to reduction in energy use, $S(C)$, is

$$
S(C)=k_{5}[1-T(C)]
$$

where

$$
\begin{aligned}
k_{5}= & \text { the energy usage of the baseline design to which the } T(C) \\
& \text { values are normalized. }
\end{aligned}
$$

Substituting Equation (VI-10) into (VI-8) yields

$$
N P W=k_{5}[1-T(C)] \cdot F(i) \cdot F C / k_{1}-\left[k_{2}+k_{3} F(i)+1\right] \cdot C
$$

'l'he optimum is found in the solution to the following equation

$$
\begin{aligned}
& \frac{\partial N P W}{\partial C}=0 \text {, or } \\
& k_{5} F(i) \cdot F C / k_{1} \cdot \frac{\partial T(C)}{\partial C}-\left[k_{2}+k_{3} F(i)+1\right]-0
\end{aligned}
$$


Differentiating $\mathrm{T}(\mathrm{C})$ of Equation (VI-9) with respect to $\mathrm{C}$ yields

$$
\frac{\partial T(C)}{\partial C}=\frac{-\alpha}{\beta}\left(1-T_{\infty}\right)\left[\frac{\beta+C}{\beta}\right]^{-(1+\alpha)}
$$

Substituting and solving for $C$ results in the expression for $C^{*}$, the optimal design cost

$$
C^{*}=B\left[H^{-1 / 1+\alpha}-1\right]
$$

where

$$
H=\frac{\beta\left(k_{2}+k_{3} F(i)+1\right) k_{1}}{\alpha k_{5}\left(1-T_{\infty}\right) \cdot F(i) \cdot F C}
$$

The most important variable factors are now obvious and include $\mathrm{k}_{1}$, the seasonal fuel efficiency, $F(i)$, (the uniform series present worth factor) which varies as a function of interest rate and length of loan term; and FC, the fuel costs. Analysis shows that a $15 \%$ change in any of these factors changes $C^{*}$ by about $10 \%$. Table 14 offers a comparison of the continuous analysis presented in this section to the discrete analysis discussed earlier. The results are very similar. Most differences are on the order of $10 \%$ or less. The larger discrepancies are due to large dollar amounts in certain incremental steps (e.g., storm windows cost $\simeq \$ 260$ ). This is shown more clearly in Figure 12, page 45 , for Washington, D.C. The continuous analysis selects a $\$ 375$ investment between discrete steps \#6 $(\$ 280)$ and \#7 (\$525). The continuous analysis results are also plotted in Figure 13, page 46 , and show excellent agreement with the earlier discrete analysis. 
TABLE 14

COMPARISON OF OPTIMIZATION ANALYSIS RESULTS

\begin{tabular}{|c|c|c|c|c|}
\hline \multirow[b]{2}{*}{ Location } & \multicolumn{2}{|c|}{$\begin{array}{c}\text { Optimal Design (1975-\$) } \\
\text { Discrete/Continuous }\end{array}$} & \multirow{2}{*}{$\begin{array}{c}\text { Percent } \\
\text { Natural } \\
\text { Gas }\end{array}$} & \multirow{2}{*}{$\begin{array}{l}\text { ifference } \\
\text { Electric }\end{array}$} \\
\hline & $\begin{array}{l}\text { Natural } \\
\text { Gas }\end{array}$ & Electric & & \\
\hline Minneapolis & $590 / 540$ & $810 / 910$ & -8 & +12 \\
\hline Cheyenne & $590 / 550$ & $820 / 910$ & -7 & +18 \\
\hline Boston & $500 / 485$ & $800 / 840$ & -4 & +6 \\
\hline Seattle & $530 / 450$ & $830 / 790$ & -16 & -5 \\
\hline Kansas City & $520 / 390$ & $820 / 760$ & -26 & -8 \\
\hline Washington, D.C. & $520 / 380$ & $670 / 730$ & -29 & +10 \\
\hline Atlanta & $280 / 320$ & $670 / 660$ & +14 & -1 \\
\hline San Diego & $100 / 110$ & $300 / 370$ & +6 & +23 \\
\hline Miami & $0 / 0$ & $30 / 40$ & 0 & +33 \\
\hline Miami (Cooling) & - & $89 / 168$ & - & +89 \\
\hline
\end{tabular}


For electrical heating the amount of energy saved is not affected as much since most of the optimal selections are toward the "flat" part of the load/cost relationship. In this area the change in load for a change in investment becomes small. This is demonstrated in Figure 14, page 47 .

For aggregate analysis the results of this study are beneficial because of their widespread applicability. Useful Equations (V-1), $(V-3),(V-4),(V-5),(V I-9)$, and $(V I-13)$ are relisted here.

$$
\begin{aligned}
& \mathrm{AHL}(1)=1.87 \mathrm{E}-2 \cdot \mathrm{HDD} \\
& \mathrm{K}=0.45 \cdot \mathrm{HDD} \\
& \mathrm{T}_{\infty}=0.36 \\
& =0.15+5.25 \mathrm{E}-5 \cdot \mathrm{HDD} \quad(\mathrm{HDD} \geq 4000) \\
& \mathrm{T}(\mathrm{C})=\mathrm{T}_{\infty}+\left(1=\mathrm{T}_{\infty}\right)\left[\frac{\beta}{\beta \cdot+\mathrm{C}}\right]^{\alpha} \\
& \left.\mathrm{C}^{*}=\mathrm{B}\left[\left(\mathrm{H}^{-1 / 1+\alpha}-1\right)\right] 4000\right)
\end{aligned}
$$

where

$$
\begin{aligned}
\mathrm{K} & =-\alpha\left(1-\mathrm{T}_{\infty}\right) / \beta, \text { initial slope, } \\
\mathrm{HDD} & =\text { annual number of heating degree days, } \\
\mathrm{T}_{\infty} & =\text { load vs. cost curve asymptote, } \\
\mathrm{T}(\mathrm{C}) & =\text { annual load for investment, } \mathrm{C}, \\
\mathrm{H} & =\frac{\beta\left(\mathrm{k}_{2}+\mathrm{k}_{3} \mathrm{~F}(\mathrm{i})+1\right) \mathrm{k}_{1}}{\alpha \mathrm{k}_{5}\left(1-\mathrm{T}_{\infty}\right) \cdot \mathrm{F}(\mathrm{i}) \cdot \mathrm{FC}}
\end{aligned}
$$




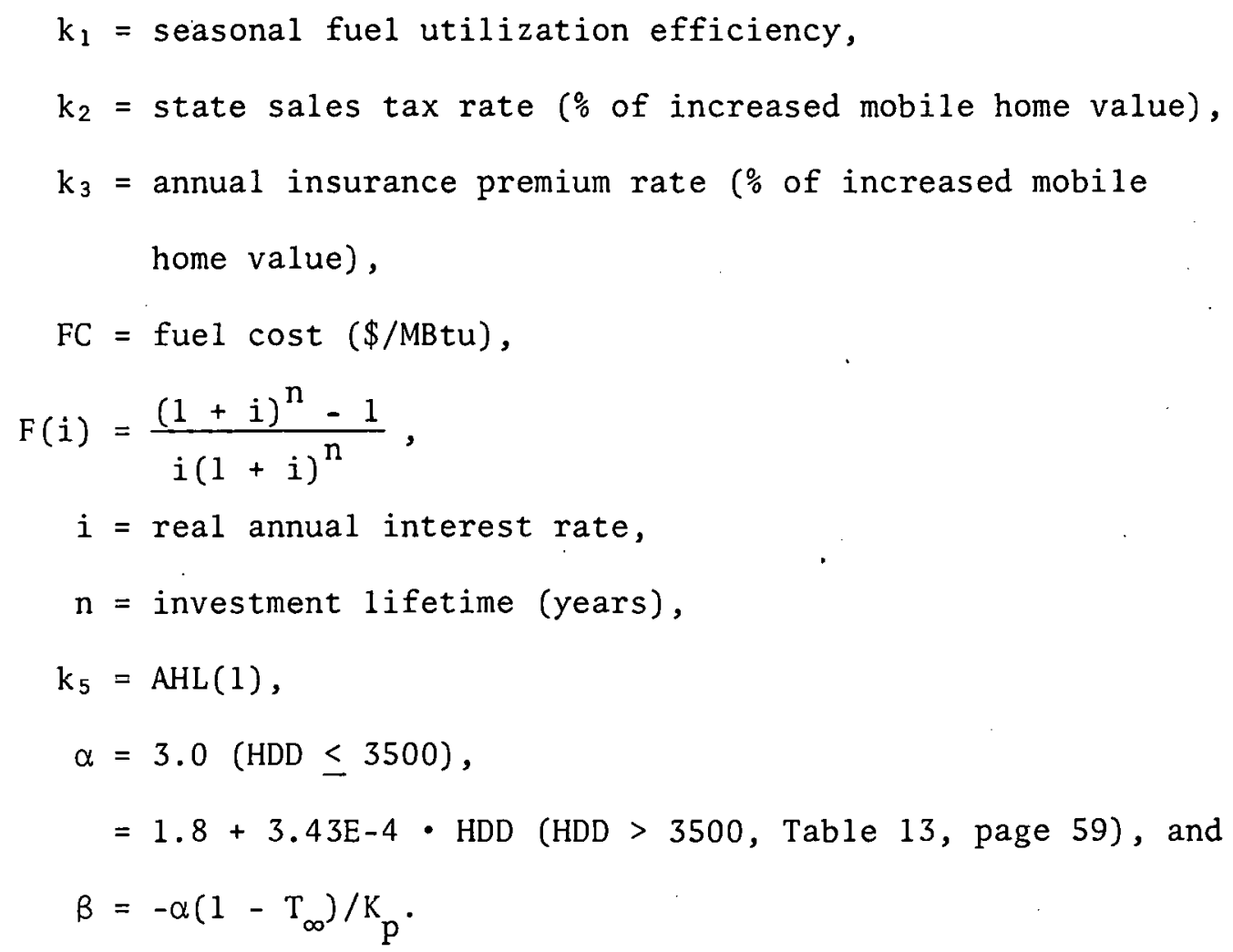

Using Equations (VI-14) through (VI-19), $C^{*}$ (the optimal investment) can be calculated as a function of annual heating degree days, insurance rate, state sales tax rate, seasonal fuel efficiency, real annual interest rate, investment lifetime and fuel cost. Energy savings are calculated as the difference between $T(C)$ values, Equation (VI-18), for a given cost $C$ and $C^{*}$. The above relationships provide a useful tool to provide energy consumption estimates and cost-effectiveness for various mobile home design options in any location in the United States. 


\section{SUMMARY AND CONCLUSIONS}

This report presents the results of detailed thermal analyses of new mobile homes in nine cities in the United States. These thermal analyses include the relationships between annual heating and cooling loads as functions of additional capital investments to reduce mobile home energy use, as shown in Figures $\mathrm{C}-1$ through $\mathrm{C}-18$ (Appendix $\mathrm{C}$ ). The energy analyses were conducted with NASA's NECAP hour-by-hour computer code. The economic analyses were conducted with a computer program written for this study.

The purpose of this study is to evaluate the optimal design (i.e., the design which minimizes the lifecycle cost of purchase and operation) for new mobile homes in each of the nine cities studied, as shown in Figures 12-16, pages 45-47, 49. Various design changes were considered, including additional wall, attic, and floor insulation, storm windows, underpinning, awnings, and home orientation.

Annual heating and cooling loads (as calculated with NECAP) vary almost linearly with annual heating and cooling degree days, respectively, for each of the cities examined (Figure 7, page 34). However, not all degree days are equal. For example, areas such as the Pacific Northwest have similar heating degree days (base $65^{\circ} \mathrm{F}$ ) as other areas in the Northeast, but with higher average winter temperatures. The number of heating degree days at a lower reference temperature is considerably smaller in the Northwest than in the Northeast. Therefore, while 1ightly insulated structures may use equivalent amounts of energy in the two 
areas, a Northwest unit with greater thermal protection would use less energy than the same unit in the Northeast.

The cost-effective order of implementation for the design options was consistent for all locations (Tables $\mathrm{C}-1$ through $\mathrm{C}-9$, Appendix $\mathrm{C}$ ) producing the relationships shown in Figures $\mathrm{C}-1$ through $\mathrm{C}-9$. A different ordering was necessary when examining a cooling-only option for Miami (Table C-10 and Figure C-9, Appendix C). Figure 9, page 39, shows how the shapes of the load/cost curves (Figures C-I through C-9) vary with location.

The optimal designs calculated with the Economic Analysis Program were compared with the 1976 HUD standards (see Figures 12, 15 and 16, on pages 45 and 49). For all but the warmest climates (heating degree days less than 2000 for natural gas and less than 500 for electric or liquid propane heating), the optimal designs calculated here involved additional investment and required less energy for heating than do the HUD standards. This suggests that the HUD standards could be more demanding. in the colder climates with requirements sensitive to location, fuel choice and fuel prices. For example, an electrically or liquid propane heated mobile home in Atlanta could save $\$ 230$ per year in heating bills with an additional investment (beyond that required by the HUD standards) of $\$ 500$, yielding a 2-year simple payback period. A natural gas heated mobile home in Kansas City could reduce heating-bills $\$ 30$ per year for an additional investment of $\$ 180$ (6-year payback). Further north in Minneapolis, the natural gas heated mobile home can save $\$ 60$ per year for a $\$ 250$ investment (1-year payback). The poorest paybacks for 
optimal investments relative to the HUD standards are about 6 years for natural gas heated homes; even this return on investment is fairly attractive.

An example of flexible thermal performance guidelines which vary according to location and fuel prices was introduced recently by the National Association of Home Builders. ${ }^{27}$ The report suggests insulation levels, addition of storm windows, etc., for any location in the United States based on achieving a certain maximum payback period and nominal interest rates. The present 1976 HUD standard for mobile homes and the wel1-known ASHRAE 90-75 are both sensitive to climate, but neither account for variations in fuel price or type.

This report also evaluates the sensitivity of these results to various parameters such as tax and insurance premium rates, heating equipment efficiency, material and labor costs, etc. Tables 10 and 11 , pages 52 and 53, summarize the results for gas and electric heating. Even for the most extreme cases (i.e., using extreme values which would encourage or discourage investment), the optimum varied at most by one stcp. The variation was less for electric or LP heating than natural. gas because optimal values were on the "flat" portions of the lodd/cust curves. The sensitivity to interest rates and fuel prices presented in Figure 18, page 55, provides a useful tool for reviewing design options.

An analysis was also developed to represent discrete points on the load/cost figures as continuous functions. Results compared well with those of the discrete analysis. Key parameters affecting the optimum selection were found to be fuel price and HVAC equipment efficiency. 
In summary, the analysis presented here provides a detailed comprehensive evaluation of mobile home thermal performance and the economics of improving the same. These results should be useful in the establishment of cost-effective mobile home standards and in future analysis of mobile home (and other structure) thermal performance. 


\section{THIS PAGE}

\section{WAS INTENTIONALLY LEFT BLANK}




\section{REFERENCES}

1. 94th Congress, Energy Conservation and Production Act, PL94-385, August 14, 1976.

2. Hirst, E. A., and J. H. Carney, The ORNL Engineering-Economic Model of Residential Energy Use, ORNL-CON-24, Oak Ridge National Laboratory, July 1978.

3. Bal1, S. J., Experimental Investigation of Retrofit Options for Mobile Homes, ORNL/CON-9, Oak Ridge National Laboratory, March 1977.

4. I'eitsma, E. J., and Bradley A. Peavy, The Thermal Performance of a Two-Bedroom Mobile Home, NBSIR 76-1182, National Bureau of Standards, January 1977.

5. Wilson, J. V., Energy Usage and Conservation in Mobile Home Heating and Cooling, ORNL/NSF/EP-91, Oak Ridge National Laboratory, August

. $\quad 1976$.

6. "Mobile Home Construction and Safety Standards," Department of Housing and Urban Development, Federal Register, December 18, 1975.

7. Standard for Mobile Homes, A119.1/NFPA 501B, National Fire Protection Association and the American National Standards Institute, 1969-1974.

8. 1970 Census of Housing, Detailed Housing Characteristics, HC(1)-B1, U.S. Department of Commerce, Bureau of the Census, July 1972; also Annual Housing Survey: 1975, General Housing Characteristics, Series H-150-75A, U.S. Department of Commerce and U.S. Department of Housing and Urban Development, Apri1 1977.

9. Quick Facts, 19\%4 Data, about Manufactured Housing Industry, Manufactured Housing Institute, June 1975.

10. NECAP, NASA's Energy-Cost Analysis Program, National Aeronautics and Space Administration, Langley Research Center, March 1975.

11. Quick Facts, May 1977, about Manufactured Housing Industry, Manufactured Housing Institute, May 1977.

12. Mobile Home Heating, C'ooling, Load C'alculations, 1976., NFPA No. 501BM, National Fire Protection Association, 1976. 
13. Boston Residential Energy Consumption, HIT 650-1, Hittman Associates, Inc. , 1976.

14. 1975 Dodge Manual for Building Constmction Pricing and Scheduling, McGraw-Hill Information Systems Company, New York, N.Y.

15. 1975 Means Cost Data, Robert Snow Means Company, Inc., Duxbury, Mass.

16. Residential Cost Handbook, Marsha11 and Swift Publication Company, Los Angeles, California, 1977.

17. Sears 1977 Catalogue for Mobile Homes, Recreational Vehicles and Comping, Sears, Roebuck and Co., 1977.

18. Sears Catalogue, Fal1/Winter/1975, Sears, Roebuck and Co., 1975.

19. Montgomery Wards CataZogue, Spring, Summer, 1977, Montgomery Wards \& Co., 1977.

20. Thermal Characteristics of Single Family Detached, Single Family Attached, Low-Rise Multifamily, Mobile Homes for Office of Technology Assessment, Congress of the United States, NAHB Research Foundation, Inc., October 1977.

21. Tape Reference Manual, TDF-14, U.S. Department of Commerce, National Oceanographic and Atmospheric Administration, (undated).

22. Final Report, Becm/NECAP, \#W-141,99, GARD, Inc., September 1976, and Fin.roy Ana.Tusias of IPL, Builiding 157 Using NECAP, Contract \#NASW-3062, GNRD, Inc., June 1977.

23. Procedure for Determining Heating and Cooling Loads for Computerized Energy Calculations, Algorithms for Building Heat Transfer Routines, Energy Calculations 1, American Society of Heating, Refrigerating, and Air-Conditioning Engineers, Inc., 1976.

24. 1975 Reader's Digest Almanac and Yearbook, Reader's Digest Association, Inc., 1975.

25. Hise, E. C., Seasonal Fuel Utilization Efficiency of Residential Heating Systems, ORNL-NSF-EP-82, Oak Ridge National Laboratory, April 1975.

26. Heat Pump Technology, CONS/2127-d, Gordian Associates, July 1977. 
27. NAHB Thermal Performance Guidelines for One and Two Family Dwellings, National Association of Home Builders, 1977.

28. ASHRAE Standard 90-75, Energy Conservation in New Buizding Design, The American Society of Heating, Refrigeration, and Air-Conditioning Engineers, Inc., 1975.

29. Residential Energy Consumption, Single Family Housing, Final Report, HUD-HAI-2, Hittman Associates, March 1973. 
APPENDIXES 
APPENDIX A

NECAP - PROGRAM DESCRIPTION AND INPUT DATA 


\section{PAGES 76 to 78 WERE INTENTIONALLY LEFT BLANK}




\section{Response Factor Program}

The response factor program portion of NECAP generates response factors to accurately determine the transient flow of heat through the building elements as they react to temperature differences across them.

The thermal characteristics of delayed surfaces (i.e., those that have significant thermal capacitance, such as walls, ceilings, and floors) are described by thickness, conductivity, density, and specific heat. Air films and spaces are merely represented by a single R-value.

Each unique parallel path between conditioned and unconditioned spaces must be characterized in the manner described above. For each delayed surface in the mobile home there are two parallel paths - one through the cavity and the other through the $2 \times 4$ studs. In order to facilitate the programming of this construction, it was assumed that each delayed surface was divided into the following classifications: window area, door area, stud area, and cavity area. The delayed surface is, therefore, described by a combination of these types of equal height and appropriate width to yield the desired surface area. Figures $A-1$ through $\Lambda-3$ contain picturial representations of this procedure for each delayed surface of the characteristic mobile described in Figure A-4. The thermal properties and dimensions that describe each parallel path for the different types of delayed surface construction (walls, ceiling/roof, floor) are listed in Figures A-5 through A-10 with their response factors. 


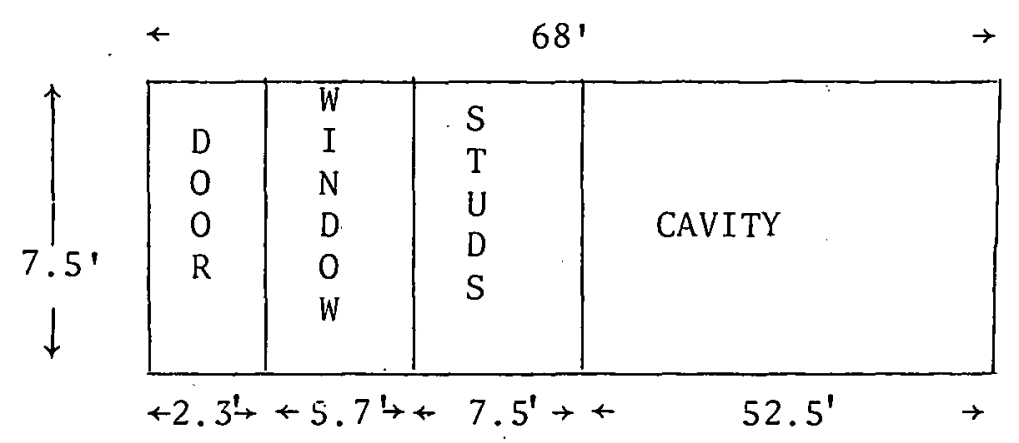

Windows

Example: NFPA \#501BM $14^{\prime} \times 62^{\prime} \quad$ studs: $2^{\prime \prime} \times 4^{\prime \prime} 16^{\prime \prime}$ o.c.

$12.3 \%$ window to floor area (total) $=107 \mathrm{ft}^{2}$

$3.3 \%$ window to floor area (ends) $=29 \mathrm{ft}^{2}$

$9.0 \%$ window to floor area (sides) $=78 \mathrm{ft}^{2}$

CHARACTERISTIC MOBILE HOME $14^{\prime} \times 68^{\prime}$

$$
\begin{aligned}
12.3 \% \text { total } & =117 \mathrm{ft}^{2} \\
3.3 \% \text { ends } & =31 \mathrm{ft}^{2}\left(15.5 \mathrm{ft}^{2} \text { each }\right) \\
9.0 \% \text { sides } & =86 \mathrm{ft}^{2}\left(43 \mathrm{ft}^{2} \text { each }\right)
\end{aligned}
$$

Doors:

Two (2) e $32^{\prime \prime} \times 78^{\prime \prime}=17 \mathrm{ft}^{2}$

Figure A-1. Wall dimensions (sides). 


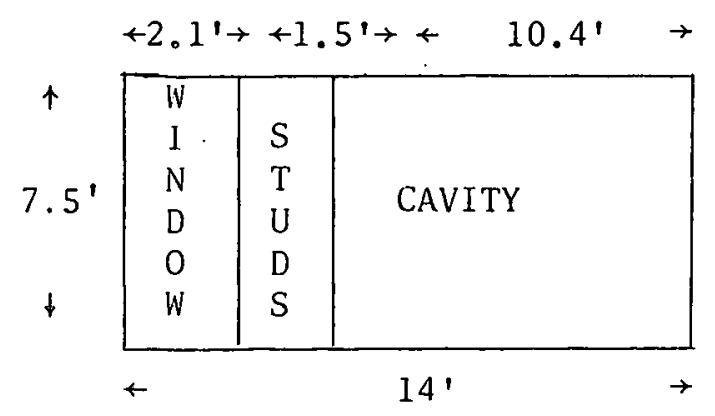

$15.5 \mathrm{ft}^{2}$ windows

studs $2^{\prime \prime} \times 4^{\prime \prime} 16^{\prime \prime}$ o.c.

Figure A-2. Wall dimensions (ends).

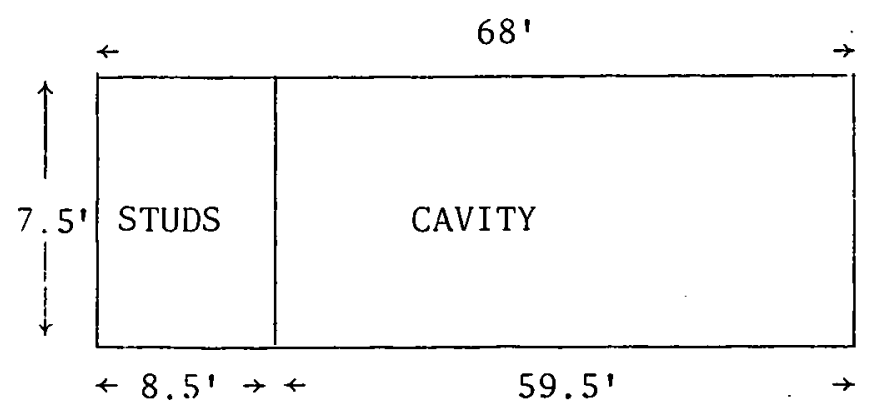

studs 2" $x 4^{\prime \prime} 16^{\prime \prime}$ o.c.

Figure A-3. Cẹiling/floor dimensions. 
ORNL-OWG 78-6182

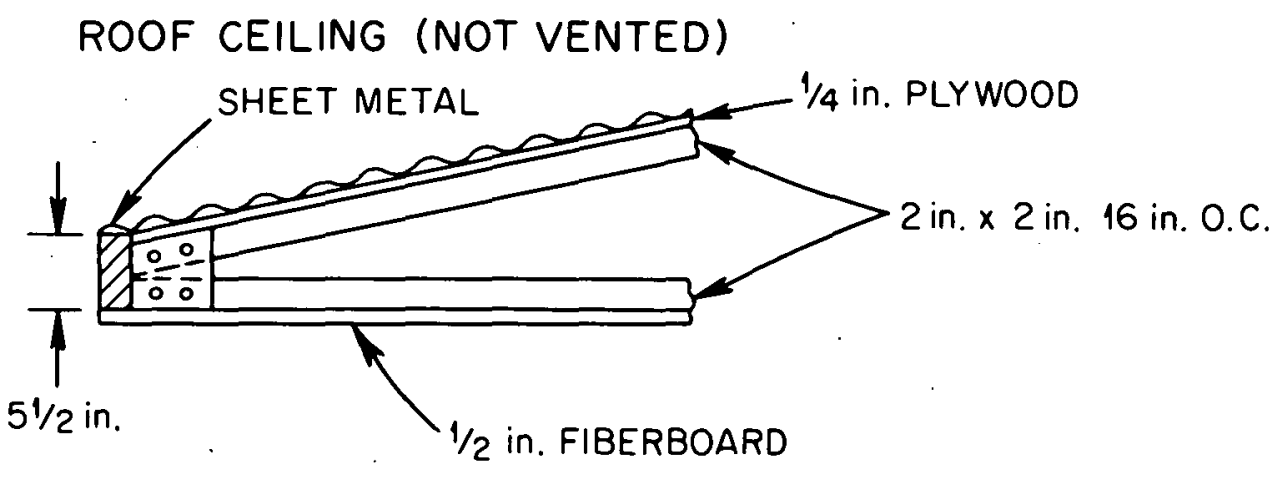

TRUSS HEIGHT AT CROWN $=14 \mathrm{in}$.

FLOOR
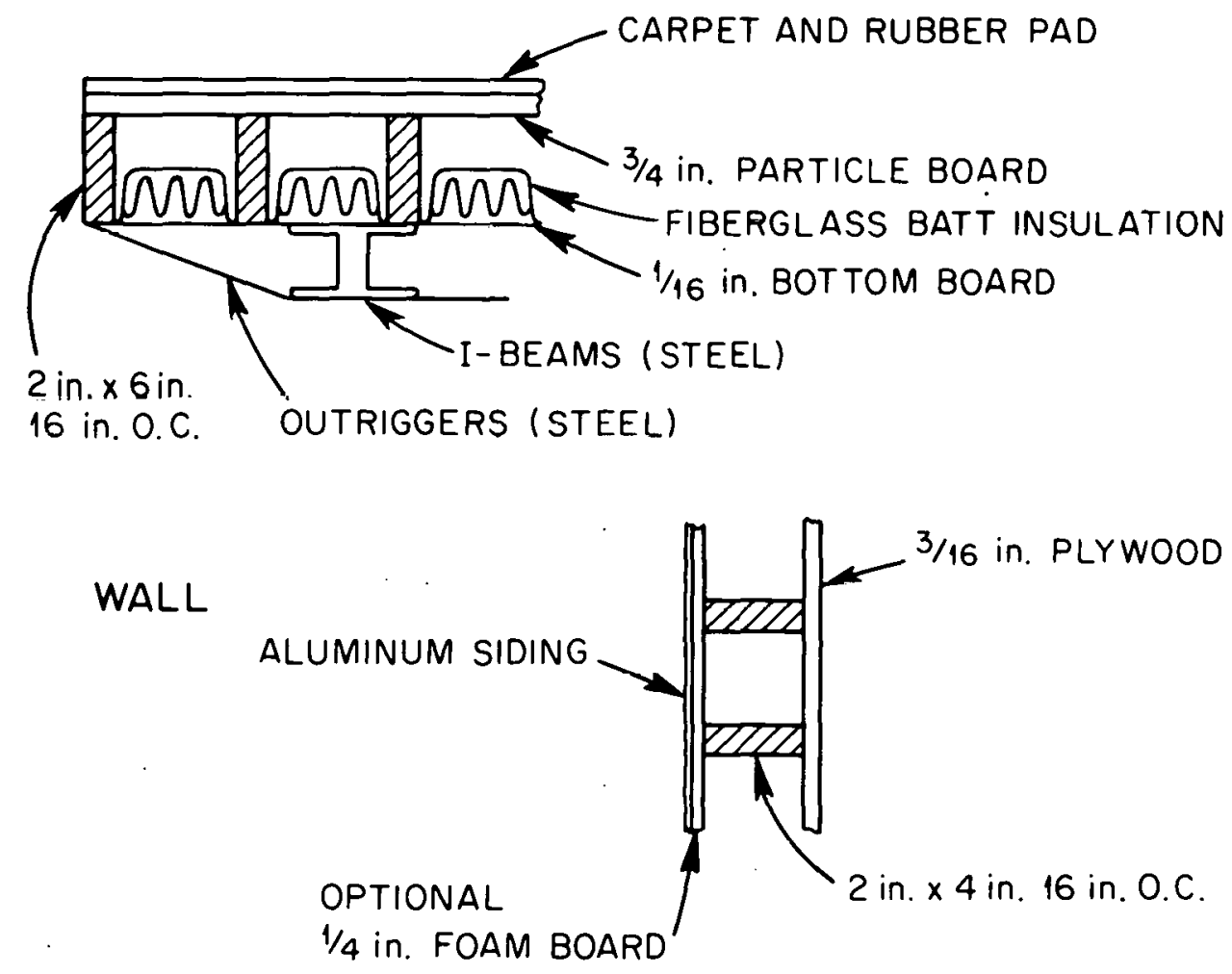

Figure A-4. Detailed construction characteristics. 
DESCRTPTION TF CONSTRUCTION

\begin{tabular}{|c|c|c|c|c|c|c|}
\hline $\begin{array}{l}\text { LAYER } \\
\text { NUMBER } \\
1 \\
2 \\
3 \\
4 \\
4\end{array}$ & $\begin{array}{l}\text { THICKNESS } \\
\text { FT } \\
0.0020 \\
0.0730 \\
0.0156 \\
0.0\end{array}$ & $\begin{array}{c}\text { CONDUCT IV ITY } \\
8 T U \text { PEP IHP I IFTI (F) } \\
99.9000 \\
0.0667 \\
0.0678 \\
0.0\end{array}$ & $\begin{array}{l}\text { DENSITY } \\
\text { LB PER CU FT } \\
490.000 \\
27.000 \\
34.000 \\
0.0\end{array}$ & $\begin{array}{l}\text { SDECIFIC HEAT } \\
\text { ETUPSR ILBIFF } \\
0.2140 \\
0 . \$ 600 \\
0.2900 \\
0.0\end{array}$ & $\begin{array}{c}\text { OESISTANCE } \\
\text { IHPIISO FTIIFI DCR BTU } \\
0.0 \\
0.0 \\
0.0 \\
1.0700\end{array}$ & $\begin{array}{l}0.024 \text { IN. SLUMINUM } \\
2 \times 4 \text { FQAMING } \\
3 / 16 \text { IN. PANELING } \\
\text { INSIDE AIO FILM }\end{array}$ \\
\hline
\end{tabular}

THERMAL CONDUCTANCE $=0.4176$ RTU DEO (HRILSO FTIIFI

DESPONSE FACTMOS FME CONSTRUCTINN TYOE NO. 1

$\begin{array}{rccc}\text { MnUR } & x & Y & Z \\ 0 & 1.4078550239 & 0.1974140406 & 0.5361648232 \\ 1 & -0.9411731958 & 0.1976799965 & -0.1082171798 \\ 2 & -0.0444847681 & 0.0204151459 & -0.0093690716 \\ 3 & -0.0041558929 & 0.0019072492 & -0.0008752872\end{array}$

NUMAER OF HDUPS REQUTREO Tr REACH COMMMN DATID =

NUMBEO TF RESPONSE FACTODS PEP SET

COMMON RATIS $=0.0934230685$

Figure A-5. Response factor program output - wall (stud portion).

OESCDIPTITN OF EThCTRUCTIOA

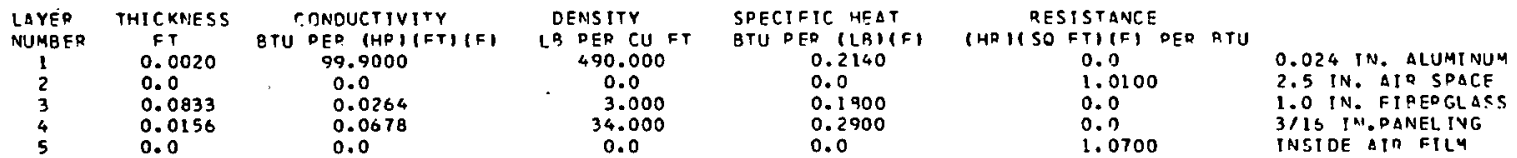

THERMAL CONDUCTANCF $=0.1830$ BTU OER. (HPIISO FTIIF)

DESDONSE FACTMRS FOR CONSTOUCTION TYOE NO. 2

\begin{tabular}{rrrr} 
HOUe & $x$ & $Y$ & \multicolumn{2}{c}{} \\
0 & 0.4133393646 & 0.1469714046 & 0.2884880900 \\
1 & -0.2306475043 & 0.0359328948 & -0.1053385139 \\
2 & -0.0000229731 & 0.0000643872 & -0.0001804591 \\
3 & -0.0000000396 & 0.0000001104 & -0.0000002107
\end{tabular}

NUMBER OF HOURS PEDUTRED TR RFACH COMMTN QATTO = 3 NUMAER AF QESPTNSF FACTOPS PFD SFT $=4$ NUMAER AF QESPINSF FACTOPS PED
COMMON PATIT $=0.0017219456$

Figure A-6. Response factor program output - wall (cavity portion). 
DFSCOIPTION DF CONSTRUCTION

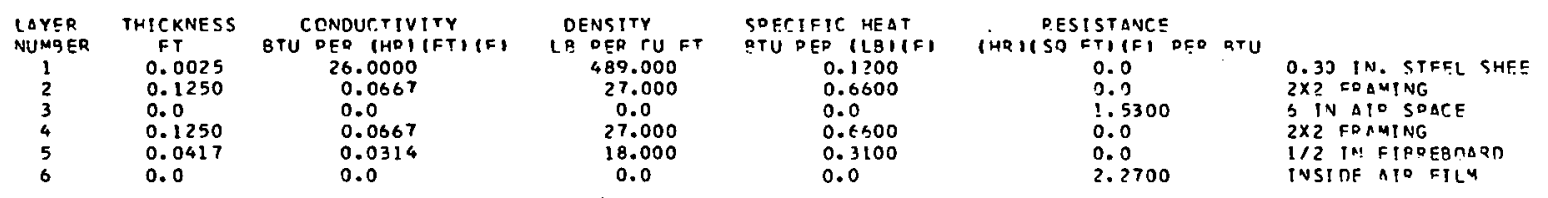

THEOMAL CONDUCTANCF $=0.1127$ ETU PEO (HOHSO FTIF)

DESDINSE FACTOPS FDR CONSTRUCTION TYDE NO. 3
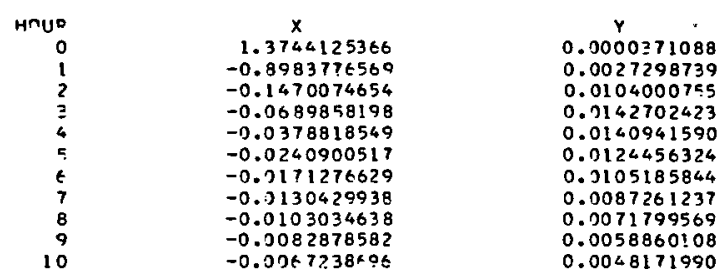
2

0.2616936564

$-0.0491497889$

$-0.0151135959$

$-0.0119696856$

$-0.0096530728$

$-0.0078418255$

$-0.0063912980$

$-0.005216866 ?$

$-0.0042611510$

$-0.0034816067$

NUMAEO OTF HEURS REOUIPED TO OEACH CMMMTN RATTO $=10$

NUMAER OF PESPTMSE FACTRQS PEP SET $=11$

CDMMDN PATIN $=0.8172718883$

Figure A-7. Response factor program output ceiling/roof (stud portion).

DESCPIPTION OF CANSTRUCTION

\begin{tabular}{|c|c|c|c|c|c|c|}
\hline $\begin{array}{l}\text { LAYER } \\
\text { PUHMEN } \\
1 \\
2 \\
3 \\
4 \\
5\end{array}$ & $\begin{array}{l}\text { THICKNESS } \\
\text { PY } \\
0.0025 \\
0.0 \\
0.0033 \\
0.0417 \\
0.0\end{array}$ & $\begin{array}{l}\text { CONDUCTIVITY } \\
\text { OTU Pen llinilitile; } \\
26.0000 \\
0.0 \\
0.0244 \\
0.0314 \\
0.0\end{array}$ & $\begin{array}{c}\text { DENSITY } \\
\text { LAEK C. } F= \\
489.000 \\
0.0 \\
3.000 \\
18.000 \\
0.0\end{array}$ & $\begin{array}{l}\text { SPECIFIC HEAT } \\
\text { OUU NEV ILBIIFI } \\
0.1200 \\
0.0 \\
0.1800 \\
0.3100 \\
0.0\end{array}$ & $\begin{array}{c}\text { RESISTANCE } \\
\text { IHW IISU }+1 \mid 1+1 \text { DER BI } \\
0.0 \\
1.5300 \\
0.0 \\
0.0 \\
2.2700\end{array}$ & $\begin{array}{l}0.30 \text { IN. STEEL SHEE } \\
9.0 \text { IN. ATD SPACE } \\
1.0 \text { IN. FIBERGLASS } \\
1 / 2 \text { IN FIBREBOARD } \\
\text { INSIOE ATR }\end{array}$ \\
\hline
\end{tabular}

THEOMAL CONCUCTANCE $=0.1207$ BTU DEP (HRILSO FTIIFI

DESPONSE FACTORS FOO CONSTRUCTION TYDE NO. 4

$\begin{array}{rccr}\text { HUUQ } & X & Y & Z \\ 0 & 0.3113120794 & 0.0842604828 & 0.2151687741 \\ 1 & -0.1870588064 & 0.0508627333 & -0.0854696035 \\ 2 & -0.0021766382 & 0.0050714500 & -0.0080964901 \\ 3 & -0.0003068519 & 0.0004898843 & -0.0007820923\end{array}$

NUMGFO JF HCUPS PEOUIRFO TO OEACH COMMON OATIO = 3

NUMBER OF RESPONSE FACTRRS DER SET $=4$
CDMMON RATIN $=0.0965964794$

Figure A-8. Response factor program output ceiling/roof (cavity portion). 
DESCOIPTITN AF CONSTRUCTION

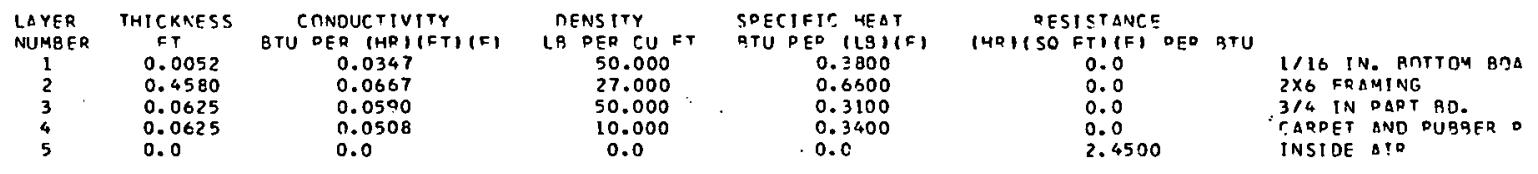

THEQMAL CTNOUCTANCE $=0.0851$ BTU DEQ $($ HQIISO FTIF)

RESOTNSE FACTIPS FOR CONSTOUCTIDN TYDE NO. 5

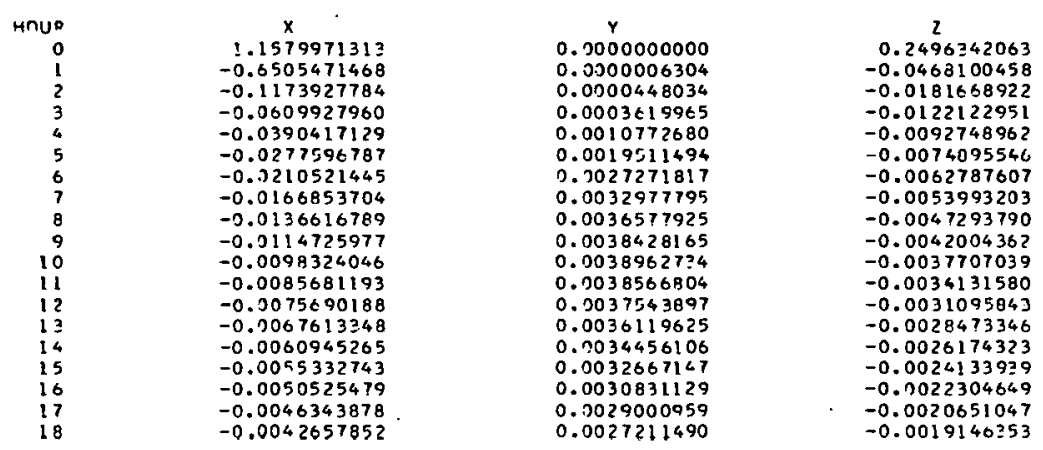

NUMPEO TF HNUPS REQUIRED TO RFACH CAMMTM PATIT = 18

NIJMREQ AF OESPINSE FACTOOS PFD SET = 19

TRMMIN PATIT $=0.931227505$ ?

Figure A-9. Response factor program output - floor (stud portion).

DESCDIPTINN TF CONSTRUCTIDN

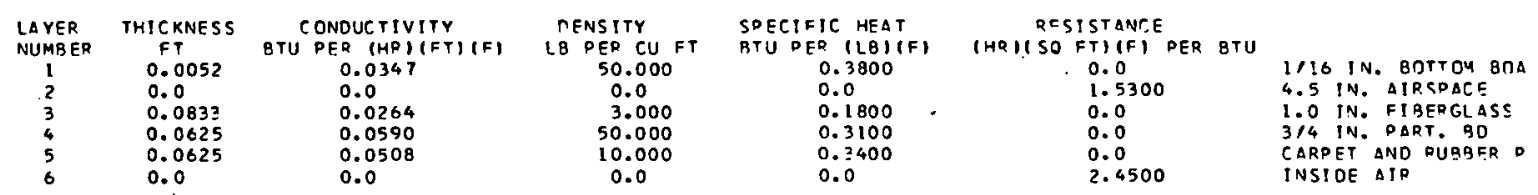

THEPMAL CONOUCTANCE $=0.1044$ BTU PEP (MRIISO FTIIF)

- ESPONSE faCtRPS ERR CONSTRUT, TION TYPE NO. 6

$\begin{array}{rr}\text { HnUe } & x \\ 0 & 0.2837545276 \\ 1 & -0.1297978759 \\ 2 & -0.0165194906 \\ 3 & -0.0110072158\end{array}$

0.0086498894
0.0296466798

0.0296466798
0.3220579021
0.0147043169
0.2487859130

$-0.0559717268$

$-0.0294864923$

NUMBER. OF HOURS PFOUTRED TO REAC.H COMMNN DATIO = 3

NUYBFQ CF RCSPANSE FACTDPS PER SET = 4

COMMON PATIS $=0.6664418578$

Figure A-10. Response factor program output - floor (cavity portion). 
Loads Program

The loads portion of NECAP computes the hourly thermal loads due to: conduction through building envelope, solar gains through windows, internal loads and infiltration.

Geographic and Climatic Data

To include the effects of weather on the hourly loads several inputs are needed in addition to the weather tape to be used. These are listed in Table A-I.

TABLE A-1

GEOGRAPHICAL AND CLIMATIC DATA

\begin{tabular}{lcccccc}
\hline Location & $\begin{array}{c}\text { Latitude } \\
\left({ }^{\circ}\right)\end{array}$ & $\begin{array}{c}\text { Longitude } \\
\left({ }^{\circ}\right)\end{array}$ & $\begin{array}{c}\text { Time } \\
\text { Zone } \\
\text { No.* }\end{array}$ & $\begin{array}{c}\text { Summer } \\
\mathrm{CN}^{* *}\end{array}$ & $\begin{array}{c}\text { Winter } \\
\mathrm{CN}^{* *}\end{array}$ & $\begin{array}{c}\text { Weather } \\
\text { Year }\end{array}$ \\
\hline Atlanta & 33.67 & 84.5 & 5 & 0.925 & 0.925 & 1958 \\
Boston & 42.33 & 71.0 & 5 & 1.00 & 1.00 & 1962 \\
Cheyenne & 41.17 & 107.0 & 7 & 1.05 & 1.05 & 1960 \\
Kansas City & 39.17 & 94.5 & 6 & 0.975 & 0.975 & 1962 \\
Miami & 25.83 & 80.5 & 5 & 0.90 & 0.85 & 1955 \\
Minneapolis & 44.83 & 93.5 & 6 & 1.025 & 1.025 & 1956 \\
San Diego & 32.67 & 117.0 & 8 & 1.05 & 0.95 & 1961 \\
Seattle & 47.5 & 122.0 & 8 & 1.05 & 0.95 & 1956 \\
Washington, D.C. & 38.83 & 77.0 & 5 & 0.975 & 0.975 & 1958 \\
\hline
\end{tabular}

$$
\begin{aligned}
* 5 & =\text { Eastern Time Zone } \\
6 & =\text { Central Time Zone } \\
7 & =\text { Mountain Time Zone } \\
8 & =\text { Pacific Time Zone } \\
* * \mathrm{CN} & =\text { Clearness number }
\end{aligned}
$$


Interna1 Loads

Schedules representing fraction of full load versus time of day are shown in Figure A-11. The full load value for lighting and equipment is calculated using the appropriate schedule so as to agree with those values for annual internal loads in Table 3 , page 9 , in the main body of the text.

Delayed Surfaces

The building delayed surfaces have been previously described by physical dimensions (Figures A-1 through A-3, pages 77-80) and response factors (Figures A-5 to A-10, pages 80-82). Pertinent additional data are: surface orientation, outer surface absorptivity, roughness index (for outside air film calculation and ground facing surface reflectivity). The absorptivity, roughness index, and reflectivity values are listed in Table $\mathrm{A}-2$.

\section{Quick Surfaces}

Quick surfaces are those that are considered to have negligible thermal capacitance. For the mobile home analysis the only surfaces considered in this category are doors. Data used to describe the doors used in this study are contained in Table A-3.

Windows

Table A-4 contains data input to NECAP used to describe glazed surfaces considered in this analysis. 


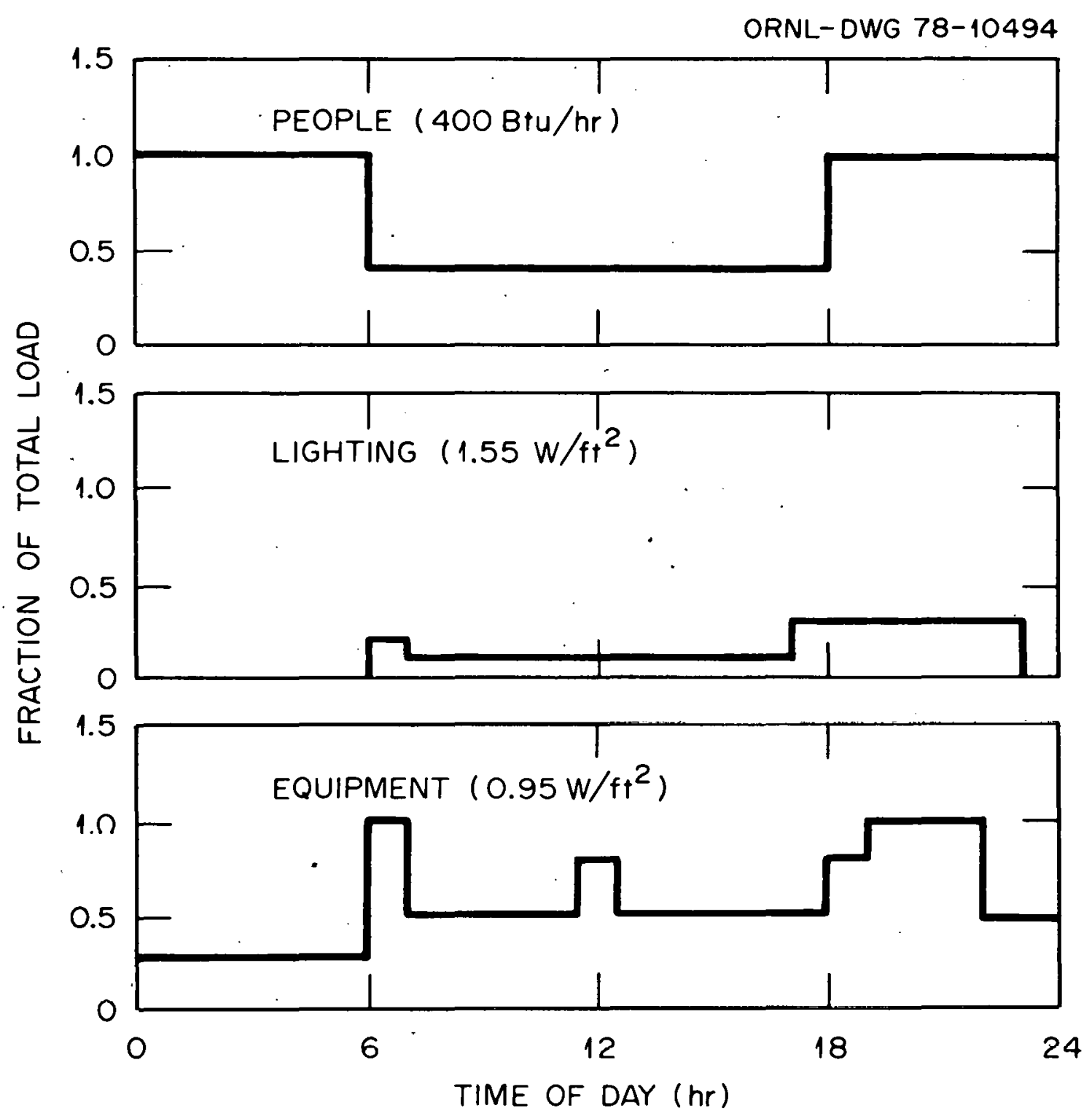

Figure A-11. Internal loads schedules. 
TABLE A-2

ADDITIONAL DELAYED SURFACE DATA

\begin{tabular}{|c|c|c|c|}
\hline Surface & Absorptivity & Roughness Index* & $\begin{array}{l}\text { Ground Facing } \\
\text { Surface Reflectivity }\end{array}$ \\
\hline Wall & 0.25 & 5 & 0.20 \\
\hline Roof & 0.25 & 5 & 0.20 \\
\hline Floor & 0.80 & 4 & 0.20 \\
\hline
\end{tabular}

*Reference 10.

TABLE A-3

QUICK SURFACE DATA

\begin{tabular}{lcccc}
\hline Type & $\begin{array}{c}\text { Outer } \\
\text { Surface } \\
\text { Absurptivity }\end{array}$ & $\begin{array}{c}\text { Surface } \\
\text { Roughness } \\
\text { Index* }\end{array}$ & $\begin{array}{c}\text { Ground } \\
\text { Facing } \\
\text { Surface } \\
\text { Reflectivity }\end{array}$ \\
\hline St-1/4" wood door & 0.55 & 0.78 & 4 & 0.2 \\
Storm door & 0.34 & 0.25 & 5 & 0.2 \\
\hline
\end{tabular}

*Reference 10.

TABLE A-4

WINDOW DATA

\begin{tabular}{|c|c|c|c|c|c|}
\hline Type & $\begin{array}{c}\text { ASHRAE } \\
\text { Shading } \\
\text { Coefficient } \\
\end{array}$ & $\begin{array}{l}\text { Form } \\
\text { tween } \\
\text { Sky } \\
\end{array}$ & $\begin{array}{l}\text { actor be- } \\
\text { window and } \\
\text { Ground }\end{array}$ & $\begin{array}{c}\text { Number } \\
\text { of } \\
\text { Panes }\end{array}$ & Index* \\
\hline $\begin{array}{l}\text { Single glass } \\
\text { Storm window }\end{array}$ & 0.55 & 0.5 & 0.5 & 1 & 1 \\
\hline (1/4" air spáce) & 0.55 & 0.5 & 0.5 & 2 & 1 \\
\hline
\end{tabular}

* Reference 10 


\section{Infiltration}

Heating or cooling loads due to infiltration can be computed by specifying a fixed number of air changes per hour for each space or by specifying air flows through cracks in the building shell. So that the effects of additional insulation and storm windows on infiltration could be accounted for individually, the crack length method was chosen.

Inputs for NECAP using the crack length method are in units of $\mathrm{ft}^{3} / \mathrm{hr} / \mathrm{ft}^{2}$ for delayed surfaces and $\mathrm{ft} / \mathrm{min} / \mathrm{ft}$ crack length (iNECAP actually uses perimeter) for quick surfaces and windows. Table A-5 lists the various input infiltration coefficients used for the different surfaces plus other pertinent information. These numbers were chosen so as to agree with measured data on infiltration due to wind ${ }^{29}$ and temperature difference. ${ }^{4}$ Also included in Table A-5 is the zero-wind, zero $\Delta \mathrm{T}$ infiltration and door usage-exhaust fan infiltration gathered from data in Reference 29. The performance of the NECAP infiltration

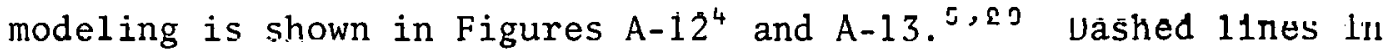
Figure A-13 represent extrapolations from the results of work by Moyers and Hittman Associates.

\section{Variable Temperature Program}

The loads calculated in the Thermal Load Analysis Program assume: a constant setpoint temperature to be maintained in the conditioned space year round and that HVAC equipment is adequate to handle any load at any time. In reality, the space temperature is not constant and may vary for several reasons. 
TABLE A-5

\section{INFILTRATION DATA*}

Surface

Infiltration Coefficient **

Wall

$1^{\prime \prime}$ insulation

$2^{\prime \prime}$ insulation

3-1/2" inșulation

ins. sheathing

\section{Floor}

Ceiling

Windows

Door

0.8

0.64

0.4

0.04

0.01

0.01

4.34

2.17

*Stack height effect $=1.2 \mathrm{ft}$; zero wind, zero $\Delta \mathrm{T}$ infiltration $=$ $25 \mathrm{cfm}$; door usage, exhaust fan $=25 \mathrm{cfm}$.

**Units are cubic feet per hour per square foot for walls, floor, and ceiling. Cubic feet per minute per foot of perimeter is used for the windows and doors. 


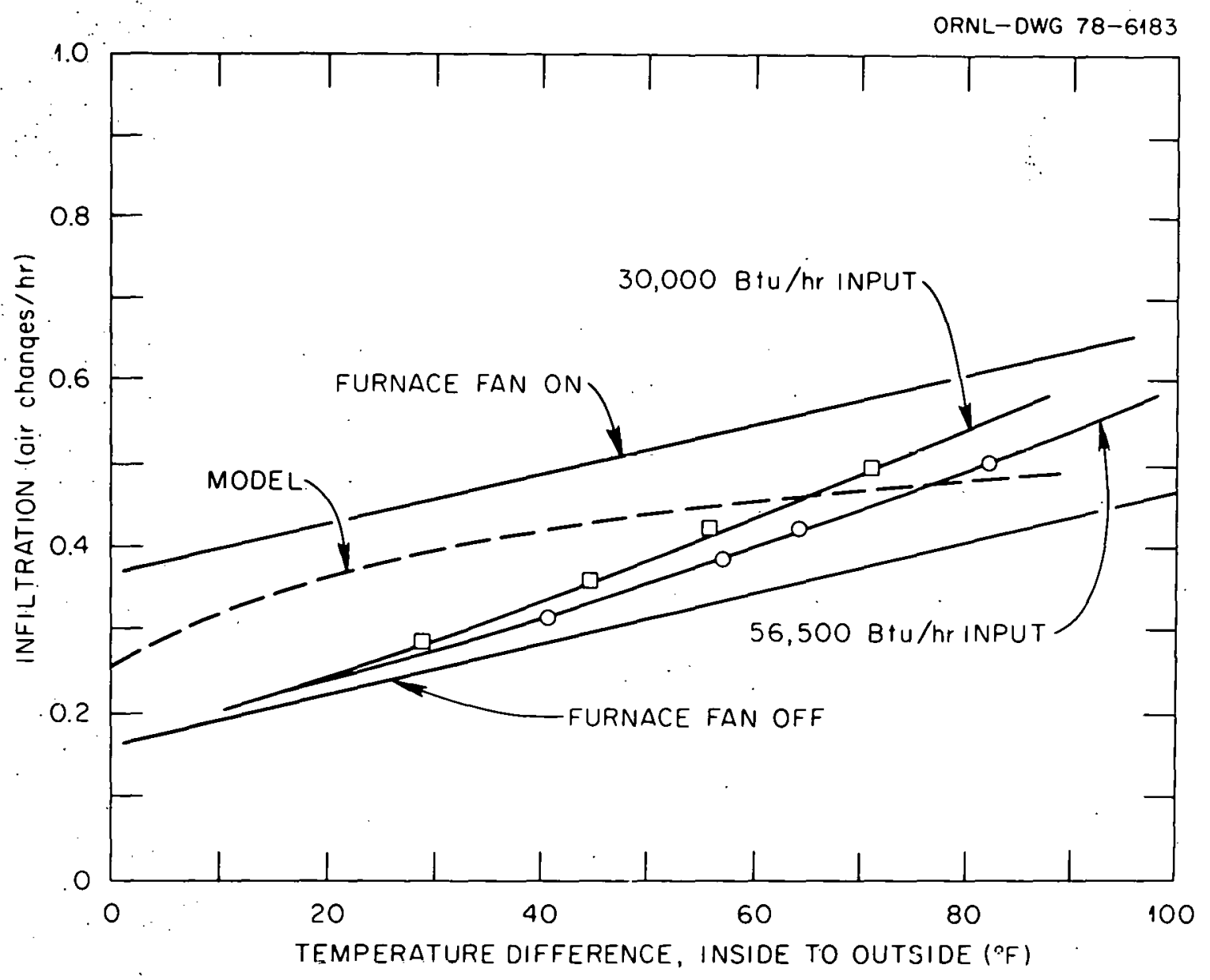

Figure. A-12. Effects of inside to outside temperature difference on infiltration. 


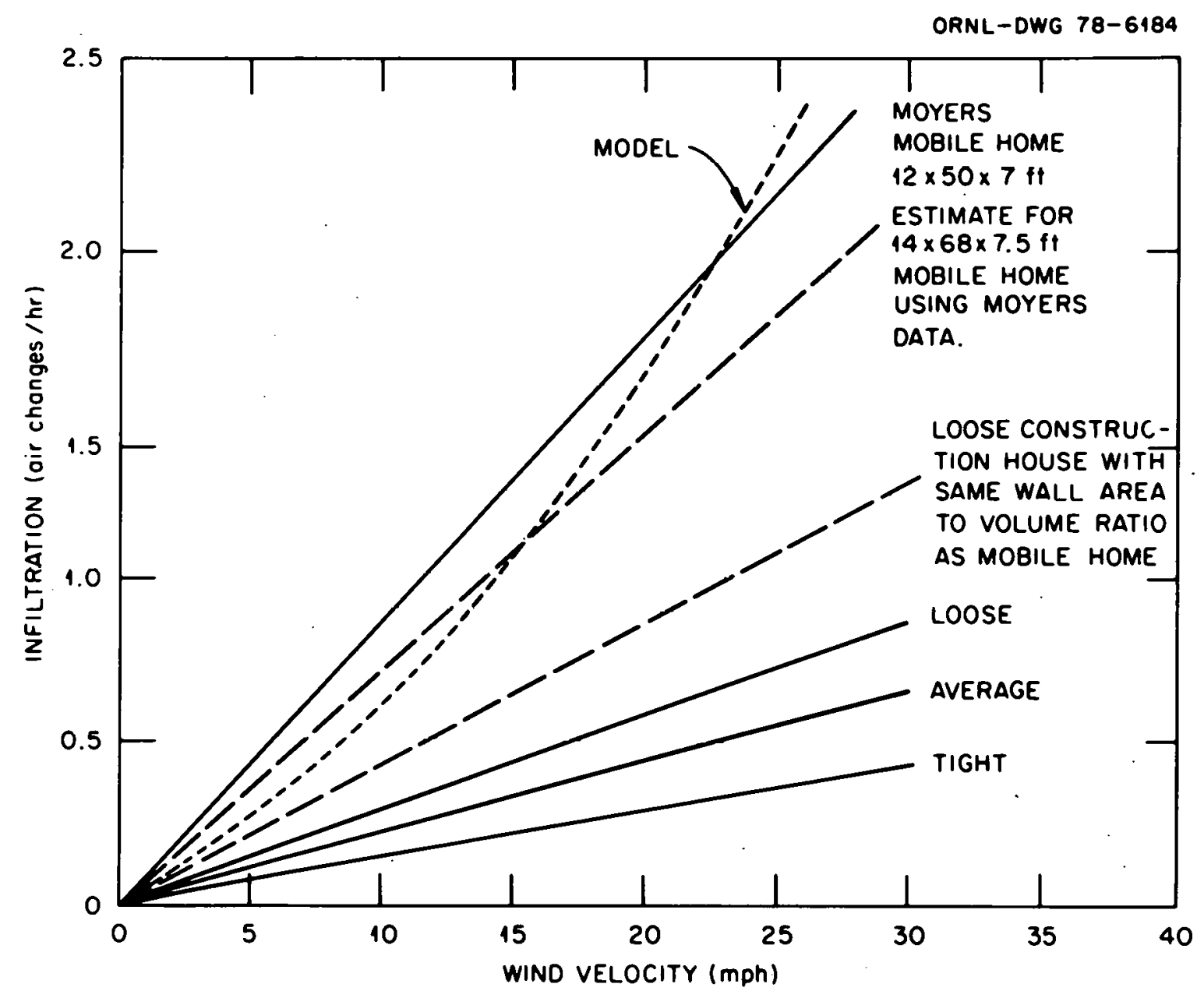

Figure A-13. Effects of wind on infiltration. 
1. thermostat deadband

2. undersized HVAC equipment

3. shutdown of equipment (often for the use of natural ventilation to meet heating or cooling requirements)

\section{Thermostat Type and Setpoints}

It is likely that the thermostat setpoint would be different for the heating and cooling seasons. In this analysis a setpoint of $78^{\circ} \mathrm{F}$ was used for the cooling season and $72^{\circ} \mathrm{F}$ for the heating season. The thermostat type is an "on-off control," typical of residential systems.

\section{HVAC Equipment Sizing}

The heating and cooling equipment is sized according to methods described in NFPA No. 501BM. The cooling equipment is chosen to the next higher size in half ton $(6000 \mathrm{Btu} / \mathrm{hr})$ increments. Heating equipment, however, is generally oversized. From conversations with furnace manutacturers it is common practice to add a safety factor of fifteen degrees Fahrenheit $\left(15^{\circ} \mathrm{F}\right)$ to the design temperature difference and then select the next size larger furnace. There are basically two reasons for this procedure. First, the sales region of most mobile home manufacturers exists within a radius of about two hundred miles of the plant. Therefore, the manufacturer wants to be certain to meet the needs of his northern-most customers. Second, it is much more economical for the manufacturer to supply an oversized furnace at the factory than to replace a number of undersized ones in the field. The increased operating costs, however, are borne by the consumer. 
Examples of a heating and cooling load calculation used for sizing the HVAC equipment are contained in Appendix D. 
APPENDIX B

ECONOMIC ANALYSIS PROGRAM LISTING 


\section{PAGES 97 to 98 WERE INTENTIONALLY LEFT BLANK}




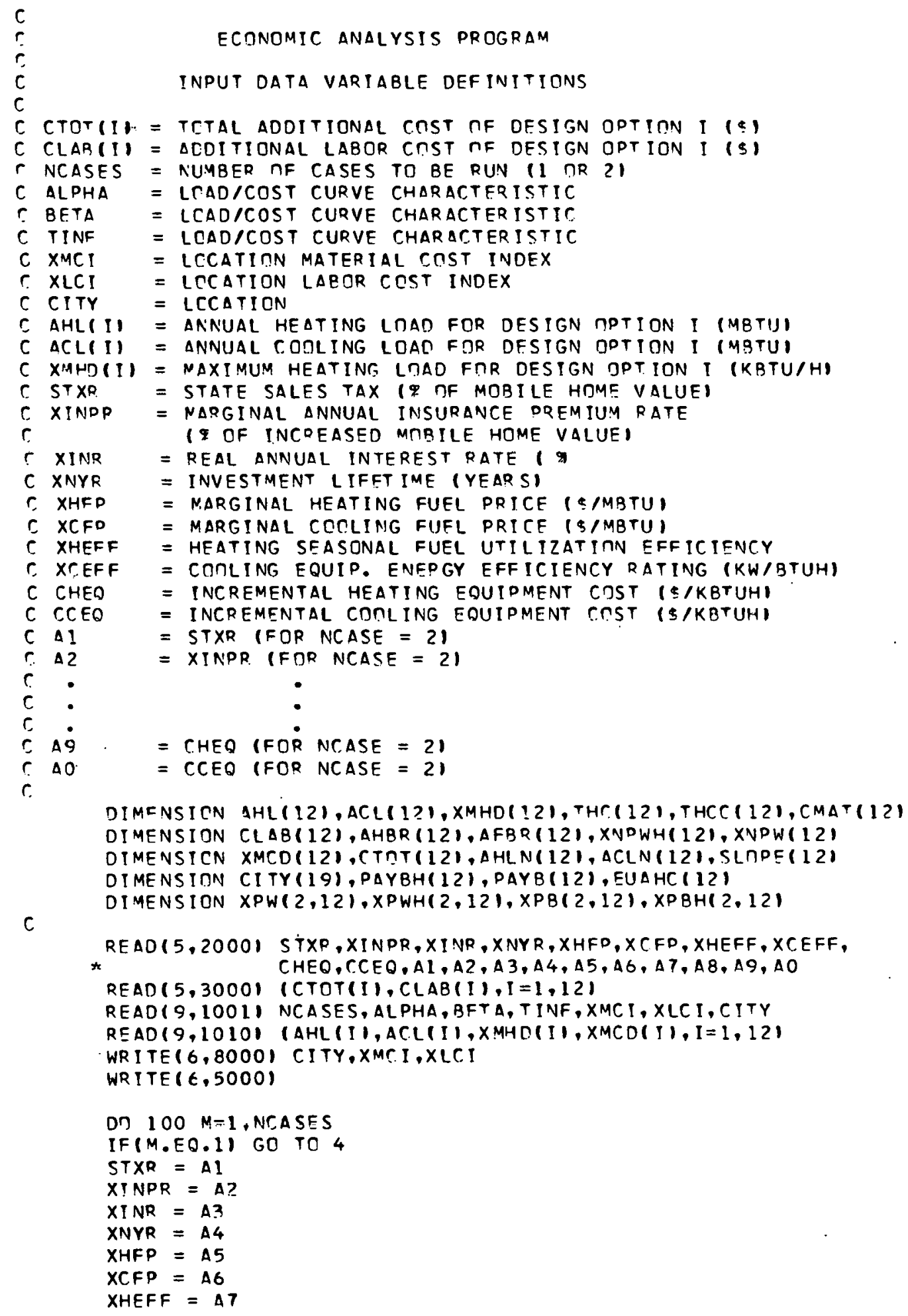




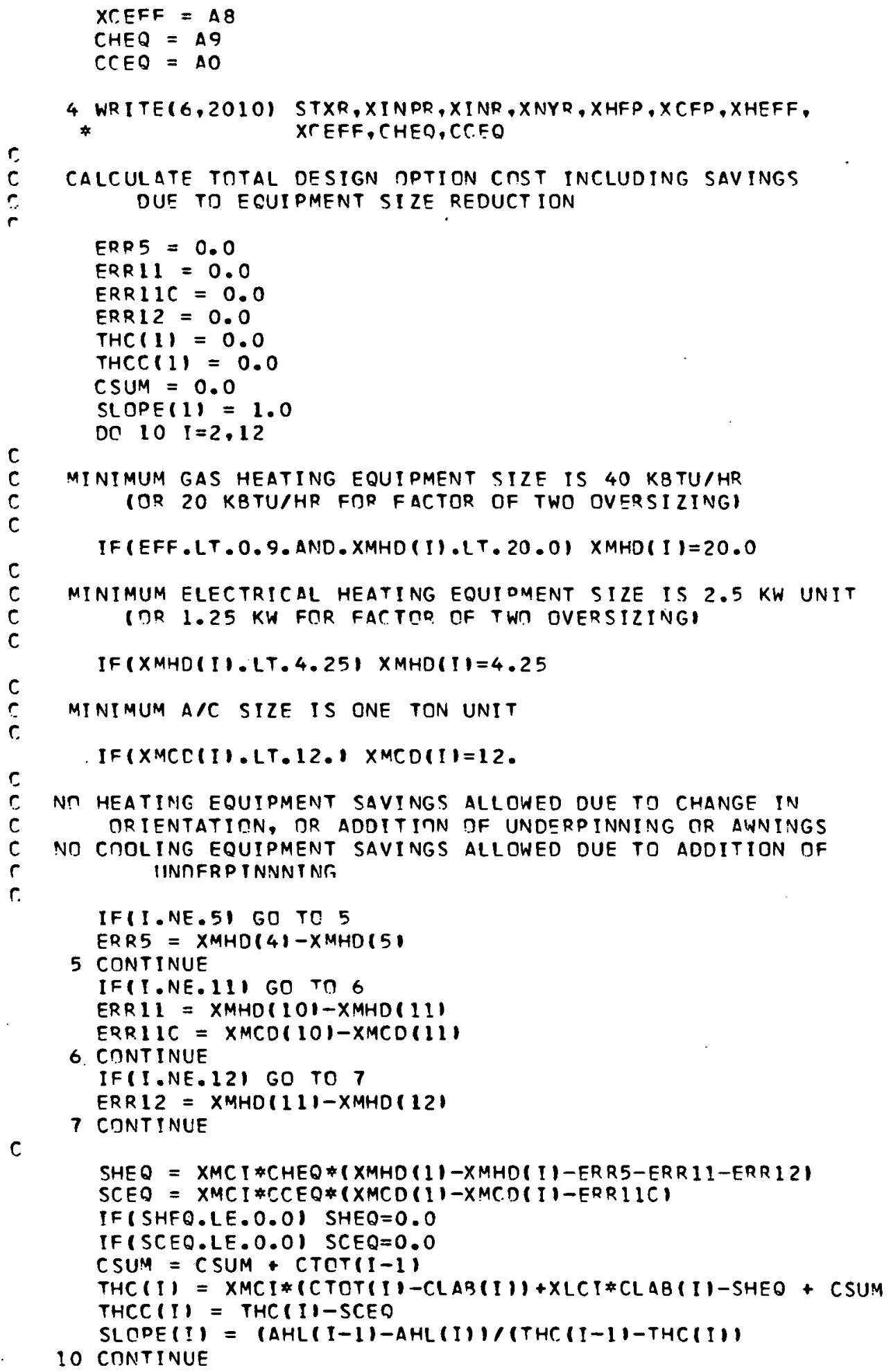




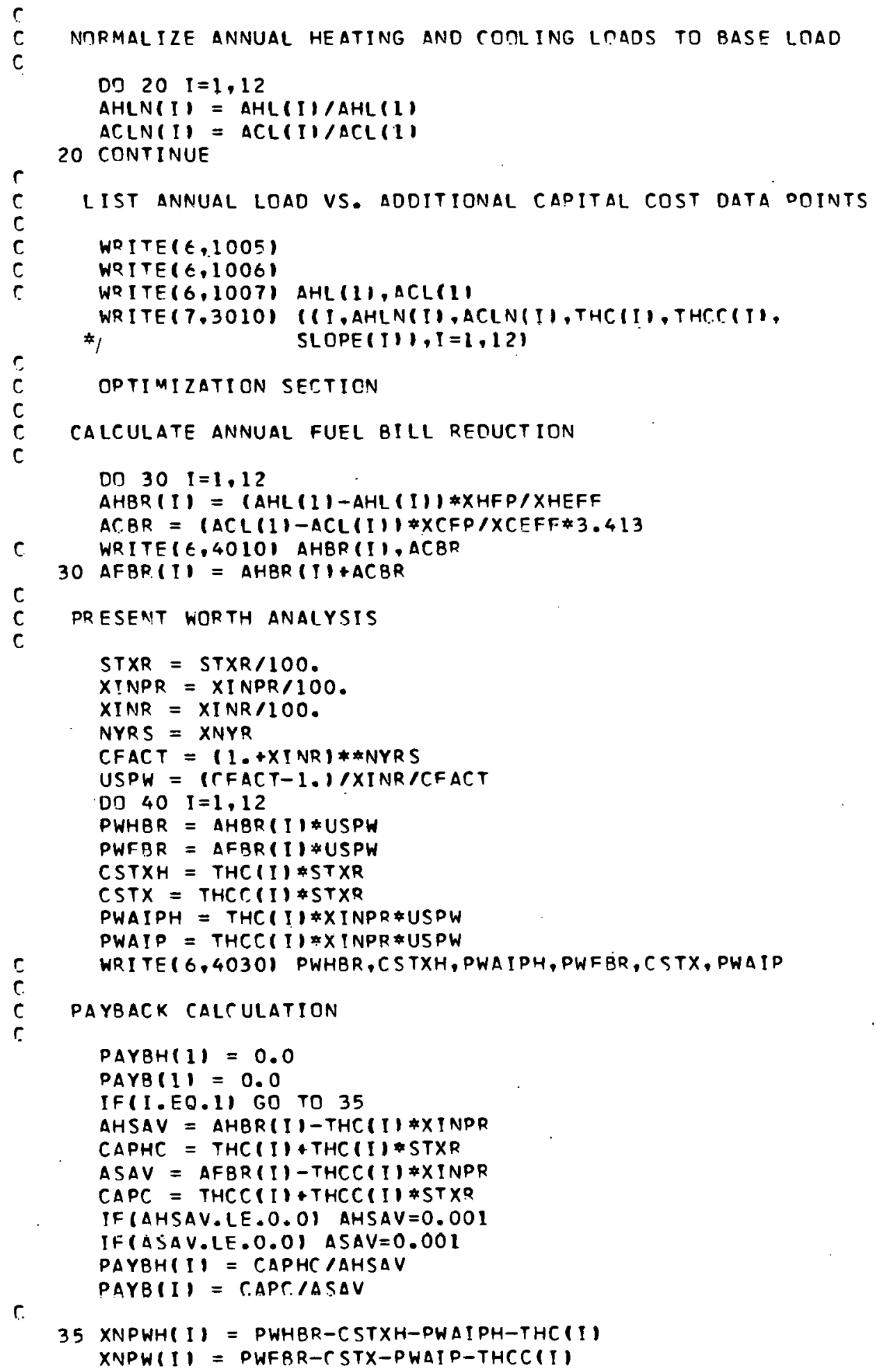




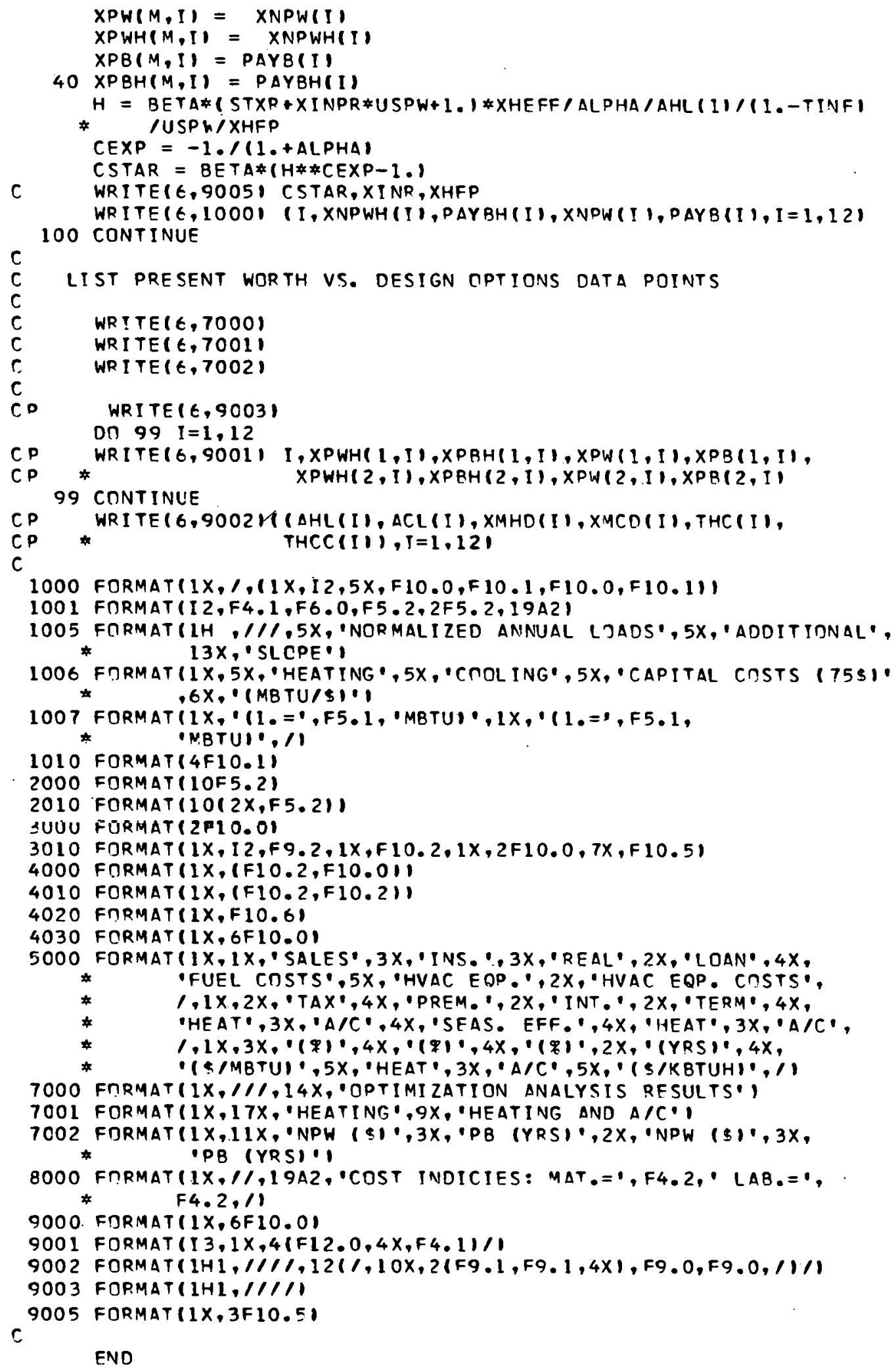

END 
APPENDIX C

ANALYSIS RESULTS FOR ALL LOCATIONS 


\section{THIS PAGE}

\section{WAS INTENTIONALLY}

LEFT BLANK 
TABLE C-1

NECAP LOAD CALCULATION RESULTS - MINNEAPOLIS

\begin{tabular}{|c|c|c|c|c|c|c|c|}
\hline \multirow{2}{*}{$\begin{array}{l}\text { Design } \\
\text { Option }\end{array}$} & \multirow{2}{*}{$\begin{array}{l}\text { Additional } \\
\text { Feature }\end{array}$} & \multicolumn{2}{|c|}{ Annual Loads (MBtu) } & \multicolumn{2}{|c|}{$\begin{array}{l}\text { Peak Demands } \\
(\mathrm{kBtu} / \mathrm{hr})\end{array}$} & \multicolumn{2}{|c|}{$\begin{array}{l}\text { Additional Initial } \\
\text { Cost }(1975-\$)^{*}\end{array}$} \\
\hline & & Heating & Cooling & Heating & Cooling & Heat Only & Heat $+A / C$ \\
\hline 1 & Baseline & 144.8 & 6.7 & 66.9 & 26.9 & 0. & 0 . \\
\hline 2 & 2" wall insulation & 132.7 & 6.8 & 61.8 & 25.0 & 22. & -8 \\
\hline 3 & $3-1 / 2 "$ ceiling ins. & 114.0 & 6.7 & 57.4 & 23.7 & 87. & 36. \\
\hline 4 & 3-1/2" wall ins. & 110.7 & 6.7 & 54.6 & 23.0 & 133. & 71. \\
\hline 5 & E-W orientation & 101.9 & 6.2 & 47.8 & 18.7 & 193. & 62. \\
\hline 6 & $3-1 / 2^{\prime \prime}$ floor ins. & 89.1 & 6.2 & 43.8 & 17.6 & 270. & 121. \\
\hline 7 & Storm windows & 71.2 & 6.3 & 36.7 & 15.8 & 516. & 338. \\
\hline 8 & 6" ceiling ins. & 67.6 & 6.3 & 35.2 & 15.4 & 588. & 404. \\
\hline 9 & $5-1 / 2 "$ floor ins. & 65.1 & 6.3 & 34.3 & 15.1 & 655. & 466. \\
\hline 10 & Insulated sheath. & 61.1 & 6.4 & 32.3 & 14.6 & 814. & 617 \\
\hline 11 & Underpinning & 58.9 & 5.8 & 27.3 & 13.5 & 1240 & 1043. \\
\hline 12 & Awnings & 60.5 & 5.0 & 27.3 & 12.8 & 1465 . & 1257. \\
\hline
\end{tabular}

*These figures include labor and material costs less savings due to HVAC equipment size reductions .

TABLE $C-\dot{2}$

NECAP LOAD CALCULATION RESULTS - CHEYENNE

\begin{tabular}{|c|c|c|c|c|c|c|c|}
\hline \multirow{2}{*}{$\begin{array}{l}\text { Design } \\
\text { Option }\end{array}$} & \multirow{2}{*}{$\begin{array}{l}\text { Additional } \\
\text { Feature }\end{array}$} & \multicolumn{2}{|c|}{ Annual Loads (MBtu) } & \multicolumn{2}{|c|}{$\begin{array}{l}\text { Peak Demands } \\
(\mathrm{kBtu} / \mathrm{hr})\end{array}$} & \multicolumn{2}{|c|}{$\begin{array}{l}\text { Additional Initial } \\
\text { Cost }(1975-\$)^{*}\end{array}$} \\
\hline & & Heating & Cooling & Heating & Cooling & Heat Only & Heat $+\mathrm{A} / \mathrm{C}$ \\
\hline 1 & Baseline & 136.2 & 6.6 & 66.4 & 17.1 & 0 & 0. \\
\hline 2 & 2" wall insulation & 124.3 & 6.6 & 60.6 & 16.4 & 20. & 9. \\
\hline 3 & $3-1 / 2 "$ ceiling ins. & 113.5 & 6.5 & 57.2 & 15.4 & 88. & 61. \\
\hline 4 & $3-1 / 2 "$ wall ins. & 106.5 & 6.4 & 55.0 & 14.8 & 136 & 99. \\
\hline 5 & E-W orientation & 92.7 & 5.9 & 41.3 & 13.2 & 196. & 133. \\
\hline 6 & $3-1 / 2^{\prime \prime}$ floor ins. & 82.9 & 5.8 & 37.5 & 12.5 & 273. & 199. \\
\hline 7 & Storm windows & 64.1 & 5.8 & 31.8 & 12.0 & 522. & 440. \\
\hline 8 & 6" ceiling ins. & 60.6 & 5.8 & 30.3 & 12.0 & 594 . & 512. \\
\hline 9 & $3-1 / 2^{\prime \prime}$ tloor ins. & 58.1 & 5.8 & 29.3 & 12.0 & 661. & 579. \\
\hline 10 & Insulated sheath. & 54.2 & 5.8 & 28.0 & 12.0 & 821. & 740. \\
\hline 11 & Underpinning & 50.7 & 5.4 & 23.1 & 12.0 & 1247 & 1166 \\
\hline 12 & Awnings & 52.5 & 4.5 & 23.1 & 12.0 & 1472 & 1391. \\
\hline
\end{tabular}

*These figures include labor and matcrial costs less savings due to HVAC equipment size reductions. 
TABLE C -3

NECAP LOAD CALCULATION RESULTS - BOSTON

\begin{tabular}{|c|c|c|c|c|c|c|c|}
\hline \multirow{2}{*}{$\begin{array}{l}\text { Design } \\
\text { Option }\end{array}$} & \multirow{2}{*}{$\begin{array}{l}\text { Additional } \\
\text { Feature }\end{array}$} & \multicolumn{2}{|c|}{ Annual Loads (MBtu) } & \multicolumn{2}{|c|}{$\begin{array}{l}\text { Peak Demands } \\
(\mathrm{kBtu} / \mathrm{hr})\end{array}$} & \multicolumn{2}{|c|}{$\begin{array}{l}\text { Additional Initial } \\
\text { Cost }(1975-\$)^{*}\end{array}$} \\
\hline & & Heating & Cooling & Heating & Cooling & Heat Only & Heat $+A / C$ \\
\hline 1 & Baseline & 124.0 & 4.1 & 95.6 & 21.2 & 0. & 0. \\
\hline 2 & 2" wall insulation & 113.3 & 4.3 & 86.7 & 20.1 & 13. & -5 \\
\hline 3 & $3-1 / 2 "$ ceiling ins. & 104.1 & 4.3 & 83.0 & 19.5 & 80. & 52. \\
\hline 4 & 3-1/2" wall ins. & . 98.1 & 4.4 & 80.4 & 19.0 & 126. & 91. \\
\hline 5 & E-W orieniation & 82.7 & 4.1 & 53.4 & 14.4 & 186. & 77. \\
\hline 6 & 3-1/2" floor ins. & 74.0 & 4.2 & 48.2 & 13.7 & 260. & 140. \\
\hline 7 & Storm windows & 54.8 & 4.4 & 40.0 & 12.7 & 503. & 367. \\
\hline 8 & 6" ceiling ins. & 54.4 & 4.5 & 38.7 & 12.4 & 575 & 434. \\
\hline 9 & $5-1 / 2$ " floor ins. & 52.3 & 4.5 & 37.8 & 12.3 & 642. & 500 \\
\hline 10 & Insulated sheath. & 48.5 & 4.7 & 33.8 & 12.0 & 796. & 649 \\
\hline 11 & Underpinning & 45.4 & 4.3 & 29.1 & 12.0 & 1222. & 1075 \\
\hline 12 & Awnings & 47.2 & 3.6 & 29.2 & 12.0 & 1447. & 1300 \\
\hline
\end{tabular}

*These figures include labor and material costs less savings due to HVAC equipment size reductions.

TABLE $\quad$ - -4

NECAP LOAD CALCULATION RESULTS - SEATTLE

\begin{tabular}{|c|c|c|c|c|c|c|c|}
\hline \multirow{2}{*}{$\begin{array}{l}\text { Design } \\
\text { Option }\end{array}$} & \multirow{2}{*}{$\begin{array}{l}\text { Additional } \\
\text { Fearure }\end{array}$} & \multicolumn{2}{|c|}{ Annua I Ioads (MBtu) } & \multicolumn{2}{|c|}{$\begin{array}{c}\text { Peàk vemands } \\
\left(\mathrm{kBtu} / \mathrm{h}_{\mathrm{L}}\right)\end{array}$} & \multicolumn{2}{|c|}{$\begin{array}{l}\text { Adull Lunal Inilial } \\
\text { Cost }(1975-\$)^{*}\end{array}$} \\
\hline & & Heating & Cooling & Heating & Cooling & Heat only & Heat $+A / C$ \\
\hline 1 & Baseline & 106.5 & 1.5 & 53.3 & 19.7 & 0 . & 0. \\
\hline 2 & 2" wall insulation & 96.8 & 1.6 & 48.5 & 18.8 & 23. & 9. \\
\hline 3 & $3-1 / 2^{\prime \prime}$ ceiling ins. & 88.0 & 1.6 & 45.9 & 18.0 & 93. & 65. \\
\hline 4 & 3-1/2" wal1 ins. & 82.4 & 1.6 & 44.2 & 17.4 & 141. & 104. \\
\hline 5 & E-W orientation & 71.4 & 1.5 & 32.2 & 14.8 & 201. & 123. \\
\hline 6 & 3-1/2" floor ins. & 63.3 & 1.5 & 29.3 & 14.0 & 281. & 190. \\
\hline 7 & Storm windows & 48.1 & 1.6 & 24.0 & 12.8 & 531. & 420. \\
\hline 8 & 6" ceiling ins. & 45.3 & 1.6 & 23.0 & 12.6 & 604. & 491. \\
\hline 9 & $5-1 / 2 "$ floor ins. & 43.2 & 1.6 & 22.4 & 12.3 & 672. & 553. \\
\hline 10 & Insulated sheath. & 40.1 & 1.7 & 20.7 & 12.0 & 832. & 708. \\
\hline 11 & Underpinning & 38.3 & 1.6 & 17.5 & 12.0 & 1258 & 1134. \\
\hline 12 & Awnings & 40.3 & 1.2 & 17.5 & 12.0 & 1483. & 1359. \\
\hline
\end{tabular}

* These figures include labur and material costs lcss savings due to HVAC equipment size. reductions. 
TABLE C-5

NECAP LOAD CALCULATION RESULTS - KANSAS CITY

\begin{tabular}{|c|c|c|c|c|c|c|c|}
\hline \multirow{2}{*}{$\begin{array}{l}\text { Design } \\
\text { Option }\end{array}$} & \multirow{2}{*}{$\begin{array}{l}\text { Additional } \\
\text { Feature }\end{array}$} & \multicolumn{2}{|c|}{ Annual Loads (MBtu) } & \multicolumn{2}{|c|}{$\begin{array}{l}\text { Peak Demands } \\
(\mathrm{kBtu} / \mathrm{hr})\end{array}$} & \multicolumn{2}{|c|}{$\begin{array}{l}\text { Additional Initial } \\
\text { Cost }(1975-\$)^{\star}\end{array}$} \\
\hline & & Heating & Cooling & Heating & Cooling. & Heat Only & Heat $+\mathrm{A} / \mathrm{C}$ \\
\hline 1 & Baseline & 85.3 & 17.4 & 57.3 & 26.4 & 0 & 0. \\
\hline 2 & 2" wall insulation & 77.8 & 17.4 & 52.9 & 24.9 & 24. & 0 \\
\hline 3 & $3-1 / 2 "$ ceiling ins. & 70.3 & 17.0 & 49.1 & 23.7 & 91. & 47. \\
\hline 4 & 3-1/2" wall ins. & 65.6 & 16.8 & 46.6 & 22.8 & 137. & 80. \\
\hline 5 & E-W orientation & 60.2 & 15.6 & 41.4 & $19 . i$ & 197. & 80 . \\
\hline 6 & 3-1/2" floor ins. & 54.0 & 15.2 & 38.0 & 18.0 & 276. & 141 \\
\hline 7 & Storm windows & 43.0 & 14.7 & 31.9 & 16.2 & 524. & 360 \\
\hline 8 & 6" ceiling ins. & 40.5 & 14.6 & 30.6 & 15.7 & 596. & 425 \\
\hline 9 & $5-1 / 2 "$ floor ins. & 38.9 & 14.6 & 29.8 & 15.5 & 663 & 489 \\
\hline 10 & Insulated sheath. & 36.5 & 14.6 & 28.1 & 15.0 & 823 & 641 \\
\hline 11 & Underpinning & 34.1 & 13.4 & 23.7 & 14.1 & 1249 & 1067 \\
\hline 12 & Awnings & 35.5 & 12.2 & 23.7 & 13.5 & 1474 & 1282. \\
\hline
\end{tabular}

*These figures include labor and material costs less savings due to HVAC equipment size reductions.

TABLE C -6

NECAP LOAD CALCULATION RESULTS - WASHINGTON, D.C.

\begin{tabular}{|c|c|c|c|c|c|c|c|}
\hline \multirow{2}{*}{$\begin{array}{l}\text { Design } \\
\text { Option }\end{array}$} & \multirow{2}{*}{$\begin{array}{l}\text { Additional } \\
\text { Feature }\end{array}$} & \multicolumn{2}{|c|}{ Annual Loads (MBtu) } & \multicolumn{2}{|c|}{$\begin{array}{l}\text { Peak Demands } \\
(\mathrm{kBtu} / \mathrm{hr})\end{array}$} & \multicolumn{2}{|c|}{$\begin{array}{l}\text { Additional Initial } \\
\text { Cost }(1975-\$)^{*}\end{array}$} \\
\hline & & Heating & Cooling & Heating & Cooling & Heat Only & Heat $+A / C$ \\
\hline 1 & Baseline & 83.3 & 11.3 & 60.6 & 25.1 & 0 . & 0. \\
\hline 2 & $2^{\prime \prime}$ wall insulation & 75.9 & 11.5 & 55.2 & 24.1 & 22. & 6. \\
\hline 3 & $3-1 / 2^{\prime \prime}$ ceiling ins. & 68.9 & 11.3 & 52.2 & $2 \overline{3} .4$ & 90. & 63. \\
\hline 4 & 3-1/2" wall ins. & 64.5 & 11.4 & 50.2 & 23.0 & 138. & 104. \\
\hline 5 & E-W orientation & 56.8 & 10.5 & 37.1 & 16.6 & 198. & 62. \\
\hline 6 & $3-1 / 2^{\prime \prime}$ floor ins. & 50.6 & 10.4 & 33.9 & 15.8 & 277. & 128 \\
\hline 7 & Storm windows & 39.3 & 10.3 & 27.9 & 14.4 & 525. & 354. \\
\hline 8 & 6" ceiling ins. & 37.0 & 10.3 & 26.8 & 14.2 & 598. & 424. \\
\hline 9 & $5-1 / 2 "$ floor ins. & 35.5 & 10.4 & 26.1 & 14.0 & 666. & 488 \\
\hline 10 & Insulated sheath. & 33.1 & 10.4 & 24.4 & 13.4 & 825. & 638 \\
\hline 11 & IInderpinning & 32.0 & 8.5 & 20.5 & 12.6 & 1251 & 1064 \\
\hline 12 & Awnings & 33.5 & 7.6 & 20.5 & 12.3 & 1470. & 1284. \\
\hline
\end{tabular}

*These figures include labor and material costs less savings due to HVAC equipment size reductions. 
TABLE C-7

NECAP LOAD CALCULATION RESULTS - ATLANTA

\begin{tabular}{|c|c|c|c|c|c|c|c|}
\hline \multirow{2}{*}{$\begin{array}{l}\therefore: \\
\text { Design } \\
\text { Option }\end{array}$} & \multirow{2}{*}{$\begin{array}{l}\text { Additional } \\
\text { Feature }\end{array}$} & \multicolumn{2}{|c|}{ Annual Loads (MBtu) } & \multicolumn{2}{|c|}{$\begin{array}{c}\text { Peak Demands } \\
(\mathrm{kBtu} / \mathrm{hr})\end{array}$} & \multicolumn{2}{|c|}{$\begin{array}{c}\text { Additional Initial } \\
\text { Cost }(1975-\$)^{\star}\end{array}$} \\
\hline & & Heating & Cooling & Heating & Cooling & Heat Only & Heat $+\mathrm{A} / \mathrm{C}$ \\
\hline 1 & Baseline & 63.1 & 16.6 & 57.4 & 23.1 & 0. & 0. \\
\hline 2 & $2 "$ wa11 insulation & 57.3 & 16.7 & 52.6 & 21.9 & 23. & 4. \\
\hline 3 & $3-1 / 2 "$ ceiling ins. & 51.8 & 16.5 & 49.4 & 20.7 & 91. & 53. \\
\hline 4 & $3-1 / 2 "$ wall ins. & 48.4 & 16.4 & 47.2 & 20.0 & 139. & 89. \\
\hline 5 & E-W orientation & 41.6 & 15.0 & 37.8 & 16.7 & 199. & 96. \\
\hline 6 & $3-1 / 2^{\prime \prime}$ floor ins. & 37.1 & 14.8 & 34.6 & 15.8 & 278. & 161. \\
\hline 7 & Storm windows & 28.1 & 14.5 & 28.4 & 14.7 & 525. & 391. \\
\hline 8 & 6" ceiling ins. & 26.3 & 14.5 & 27.3 & 14.5 & 598. & 461. \\
\hline 9 & $5-1 / 2^{\prime \prime}$ floor ins. & 25.1 & 14.5 & 26.6 & 14.3 & 666. & 525. \\
\hline 10 & Insulated sheath. & 23.3 & 14.5 & 24.8 & 13.9 & 825 & 678 \\
\hline 11 & Underpinning & 21.5 & 13.7 & 20.4 & 12.5 & 1251 & 1104 \\
\hline 12 & Awnings & 22.8 & 12.4 & 21.0 & 12.7 & 1476. & 1332. \\
\hline
\end{tabular}

*These figures include labor and material costs less savings due to HVAC equipment size reductions.

TABLE $\mathrm{C}-8$

NECAP LOAD CALCULATION RESULTS - SAN DIEGO

\begin{tabular}{|c|c|c|c|c|c|c|c|}
\hline \multirow{2}{*}{$\begin{array}{l}\text { Design } \\
\text { Uptinn }\end{array}$} & \multirow{2}{*}{$\begin{array}{l}\text { Additional } \\
\text { Feature }\end{array}$} & \multicolumn{2}{|c|}{ Annual Loads (MBtu). } & \multicolumn{2}{|c|}{$\begin{array}{l}\text { Peak Demands } \\
(\mathrm{kBtu} / \mathrm{hr})\end{array}$} & \multicolumn{2}{|c|}{$\begin{array}{l}\text { Adrlitinnal Tnitial } \\
\text { Cost }(1975-\$)^{*}\end{array}$} \\
\hline & & Heating & Cooling & Heating & Cooling & Ileat Only & Heat $+A / C$ \\
\hline 1 . & Baseline & 20.0 & 3.1 & 16.7 & 22.0 & 0. & 0. \\
\hline 2 & 2" wall insulation & 17.2 & 3.3 & 15.2 & 20.9 & 31. & 14. \\
\hline 3 & $3-1 / 2 "$ ceiling ins. & 14.0 & 3.5 & 13.7 & 19.6 & 101. & 65. \\
\hline 4 & 3-1/2" wall ins. & 12.3 & 3.6 & 12.8 & 18.6 & 154. & 100 \\
\hline 5 & E-W orientation & 11.2 & 3.5 & 12.1 & 17.9 & 214. & 149 \\
\hline 6 & $3-1 / 2^{\prime \prime}$ floor ins. & 9.2 & 3.6 & 11.0 & 16.7 & 299. & 214 \\
\hline 7 & Storm windows & 5.6 & 4.0 & 9.4 & 15.0 & 558. & 446 \\
\hline 8 & 6" ceiling ins. & 4.7 & 4.2 & 8.8 & 14.6 & 632. & 514 \\
\hline$\dot{y}$. & $3-1 / 2^{\prime \prime}$ floor ins. & 4.2 & 4.2 & 8.5 & 14.2 & 700 & 575 \\
\hline 1.0 & Insulated sheath. & 3.6 & 4.4 & 8.5 & 13.9 & 864. & 735 \\
\hline 11 & Underpinning & 3.3 & 4.5 & 8.5 & 12.5 & 1290 & 1161 \\
\hline 12 & Awnings & 4.0 & 3.6 & 8.5 & 12.0 & 1515 & .1378 \\
\hline
\end{tabular}

*These figures include labor and material costs less savings due to HVAC equipment size reductions. 
TABLE C-9

NECAP LOAD CALCULATION RESULTS - MIAMI

\begin{tabular}{|c|c|c|c|c|c|c|c|}
\hline \multirow{2}{*}{$\begin{array}{l}\text { Design } \\
\text { Option }\end{array}$} & \multirow{2}{*}{$\begin{array}{l}\text { Additional } \\
\text { Feature }\end{array}$} & \multicolumn{2}{|c|}{ Annual Loads (MBtu) } & \multicolumn{2}{|c|}{$\begin{array}{c}\text { Peak Demands } \\
(\mathrm{kBtu} / \mathrm{hr})\end{array}$} & \multicolumn{2}{|c|}{$\begin{array}{l}\text { Additional Initial } \\
\text { Cost }(1975-\$)^{*}\end{array}$} \\
\hline & & Heating & Cooling & Heating & Cooling & Heat Only & Heat $+\mathrm{A} / \mathrm{C}$ \\
\hline 1 & Baseline & 4.3 & 35.9 & 23.5 & 28.2 & 0. & 0. \\
\hline 2 & 2" wall insulation & 3.8 & 35.9 & 21.4 & 26.4 & 30. & 1. \\
\hline 3 & 3-1/2" ceiling ins. & 3.1 & 35.6 & 19.9 & 25.5 & 102. & 59. \\
\hline 4 & $3-1 / 2^{\prime \prime}$ wall ins. & 2.8 & 35.2 & 18.9 & 24.9 & 152. & $1 \mathrm{nn}$ \\
\hline 5 & $E-W$ orientation & 2.2 & 33.4 & 16.0 & 17.9 & 212 & 48. \\
\hline 6 & $3-1 / 2^{\prime \prime}$ floor ins. & 1.8 & 32.6 & 14.5 & 16.8 & 296. & 113 \\
\hline 7 & Storm windows & 1.1 & 31.3 & 11.8 & 15.3 & 552. & 346. \\
\hline 8 & 6" ceiling ins. & 1.0 & 31.3 & 11.3 & 15.0 & 627 & 416 \\
\hline 9 & $5-1 / 2$ " floor ins. & 0.9 & 31.1 & 10.9 & 14.8 & 695 & 480 \\
\hline 10 & Insulated sheath. & 0.8 & 31.1 & 10.3 & 14.0 & 857 & 630 \\
\hline 11 & Underpinning & 0.7 & 30.0 & 8.5 & 13.1 & 1283. & 1056 \\
\hline 12 & Awnings & 0.8 & 27.5 & 8.5 & 12.6 & 1508 . & 1273 \\
\hline
\end{tabular}

*These figures include labor and material costs less savings due to HVAC equipment size reductions.

TABLE C-10

NECAP LOAD CALCULATION RESULTS - MIAMI (Cooling)

\begin{tabular}{|c|c|c|c|c|c|c|c|}
\hline \multirow{2}{*}{$\begin{array}{l}\text { Design } \\
\text { Option }\end{array}$} & \multirow{2}{*}{$\begin{array}{l}\text { Additional } \\
\text { Feature }\end{array}$} & \multicolumn{2}{|c|}{ Annual Loads (MBtu) } & \multicolumn{2}{|c|}{$\begin{array}{l}\text { Peak Demands } \\
(\mathrm{kBtu} / \mathrm{hr})\end{array}$} & \multicolumn{2}{|c|}{$\begin{array}{l}\text { Additional Initial } \\
\text { Cost }(1975-\$)^{\star}\end{array}$} \\
\hline & & Cooling & Heating & Cooling & Heating & Cool Only & Heat $+A / C$ \\
\hline 1 & Baseline & 35.9 & 4.3 & 28.2 & 23.5 & 0. & 0. \\
\hline 8 & E-W oriontation & 31.1 & 3.1 & 20.3 & 19.9 & 40. & $=17$ \\
\hline 12 & Awnings & 31.3 & 3.8 & 19.6 & 20.1 & 390. & 336. \\
\hline 6 & $3-1 / 2 "$ floor ins. & 30.7 & 3.2 & 18.3 & 18.2 & 474 . & 389. \\
\hline 3 & $3-1 / 2 "$ ceiling ins. & 30.3 & 2.6 & 17.7 & 16.9 & 550. & 445. \\
\hline 7 & storm windows & 28.9 & 1.6 & 16.2 & 13.8 & 809 . & 654. \\
\hline 11 & Underpinning & 28.2 & 1.4 & 15.2 & 12.0 & 1233. & 1049 \\
\hline 2 & 2" wall insulation & 27.5 & 0.8 & 12.6 & 12.0 & 1295. & 1111. \\
\hline 4 & 3-1/2" wall ins. & 27.5 & 0.8 & 12.6 & 12.0 & 1330 . & 1146. \\
\hline 8 & 6" ceiling ins. & 27.5 & 0.8 & 12.6 & 12.0 & 1383 & 1199. \\
\hline 9 & $5-1 / 2^{\prime \prime}$ floor ins. & 27.5 & 0.8 & 12.6 & 12.0 & 1459. & 1275 . \\
\hline 10 & Insulated sheath. & 27.5 & 0.8 & 12.6 & 12.0 & 1623. & 1439. \\
\hline
\end{tabular}

* These figures include labor and material costs less savings due to HVAC equipment size reductions. 


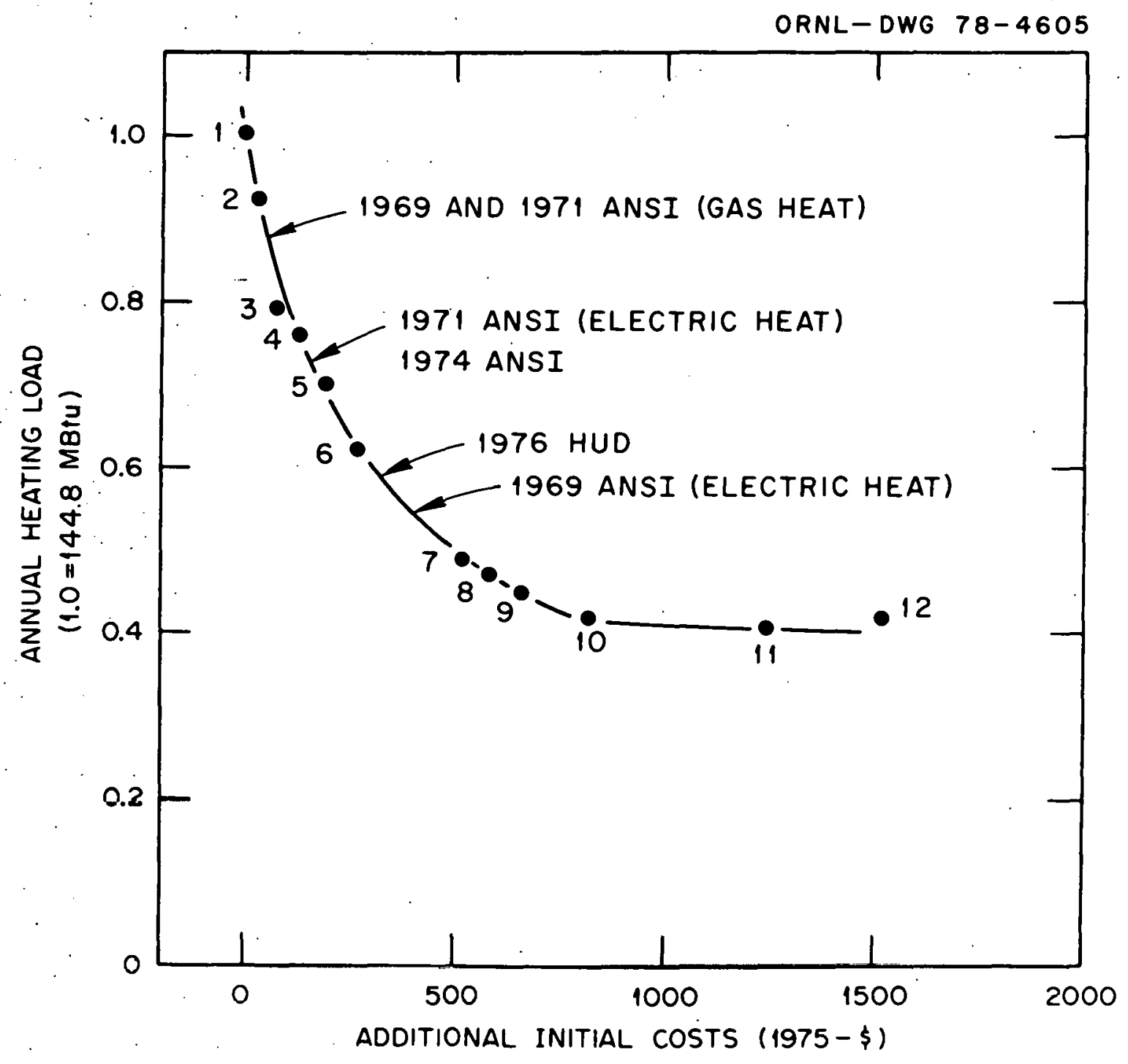

Figure C-1. Load/cost relationship - Minneapolis. 


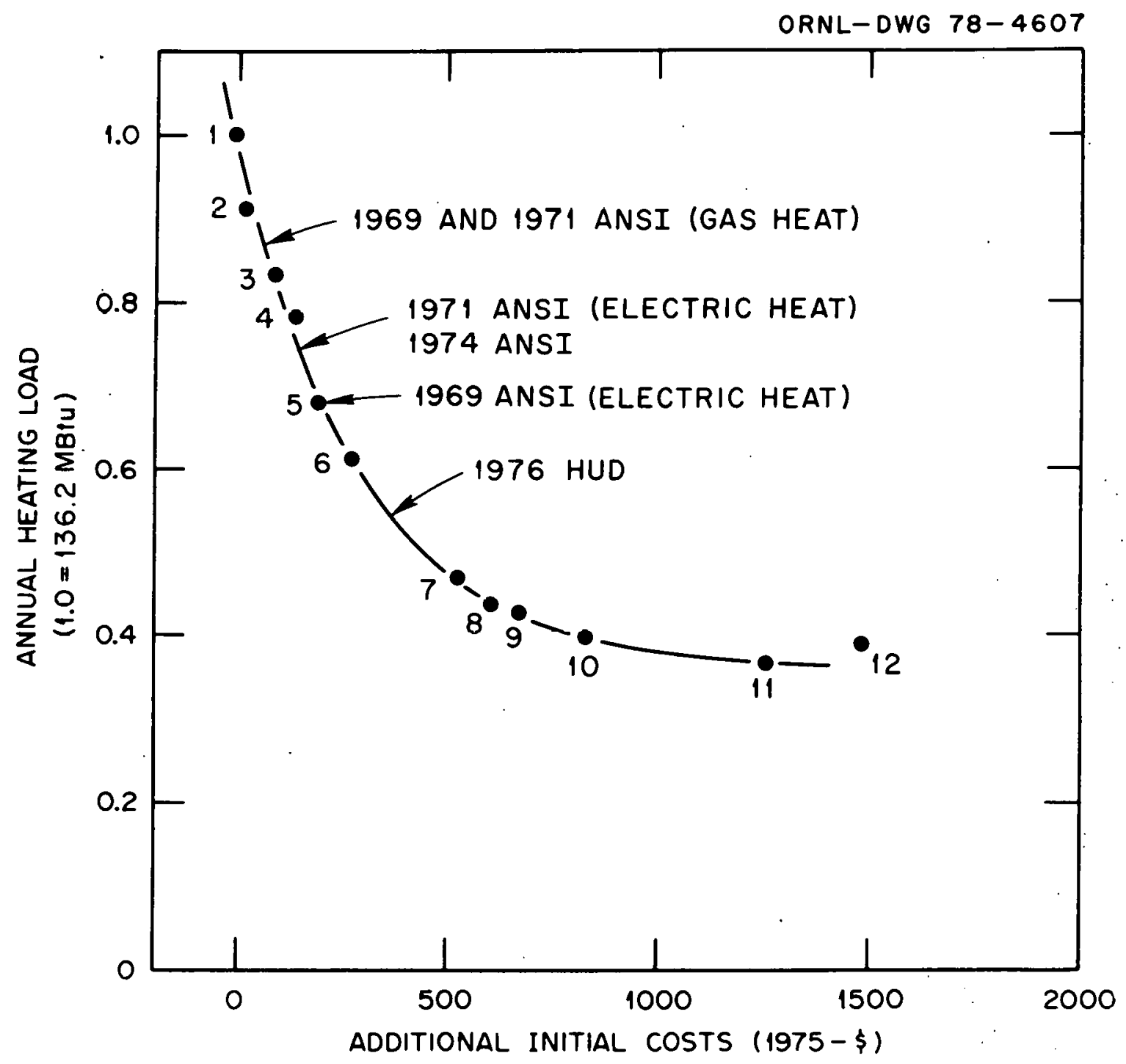

Figure C-2. Load/cost relationship - Cheyenne. 


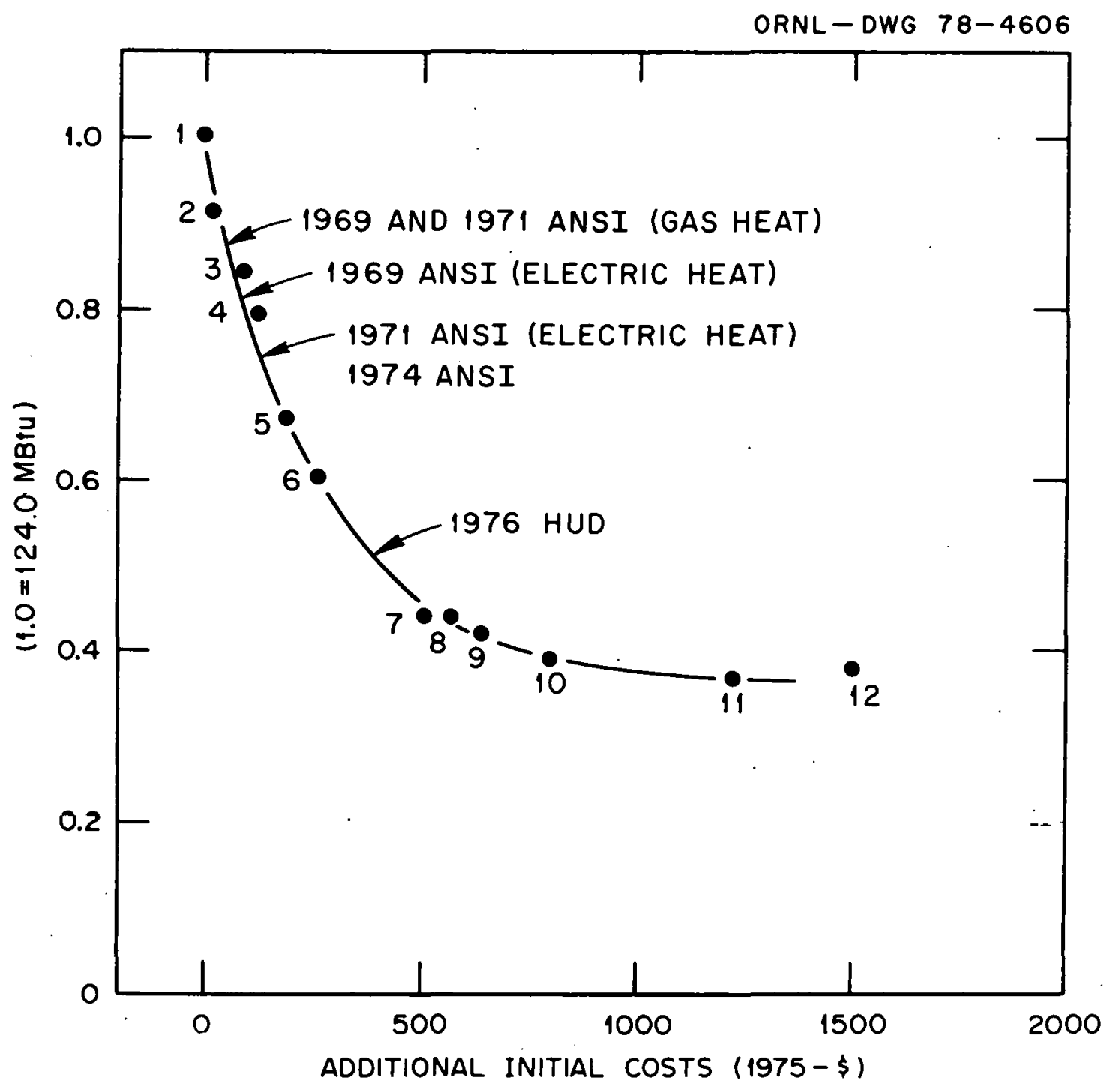

Figure C-3. Load/cost relationship - Boston. 


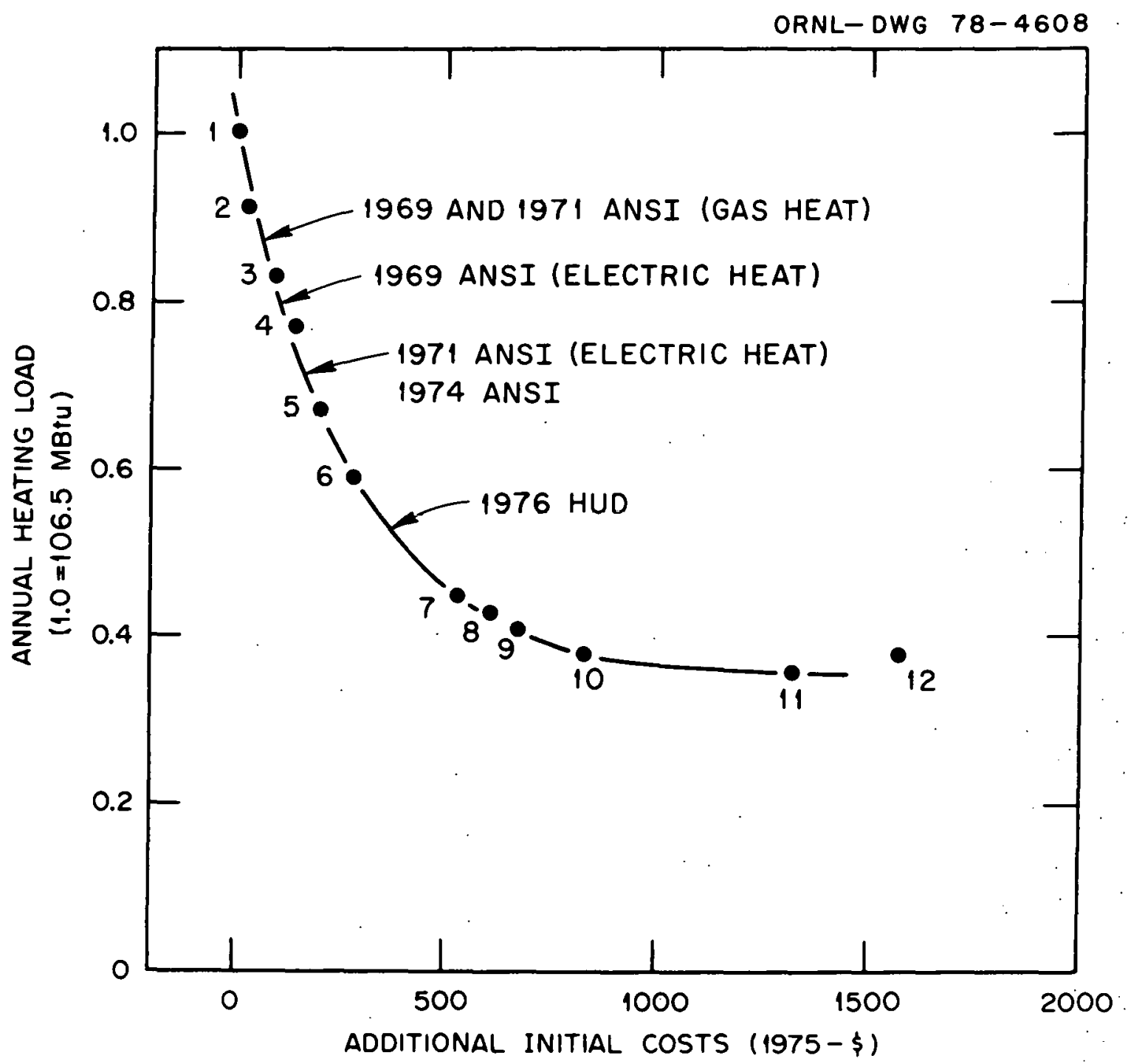

Figure C-4. Load/cost relationship - Seattle. 


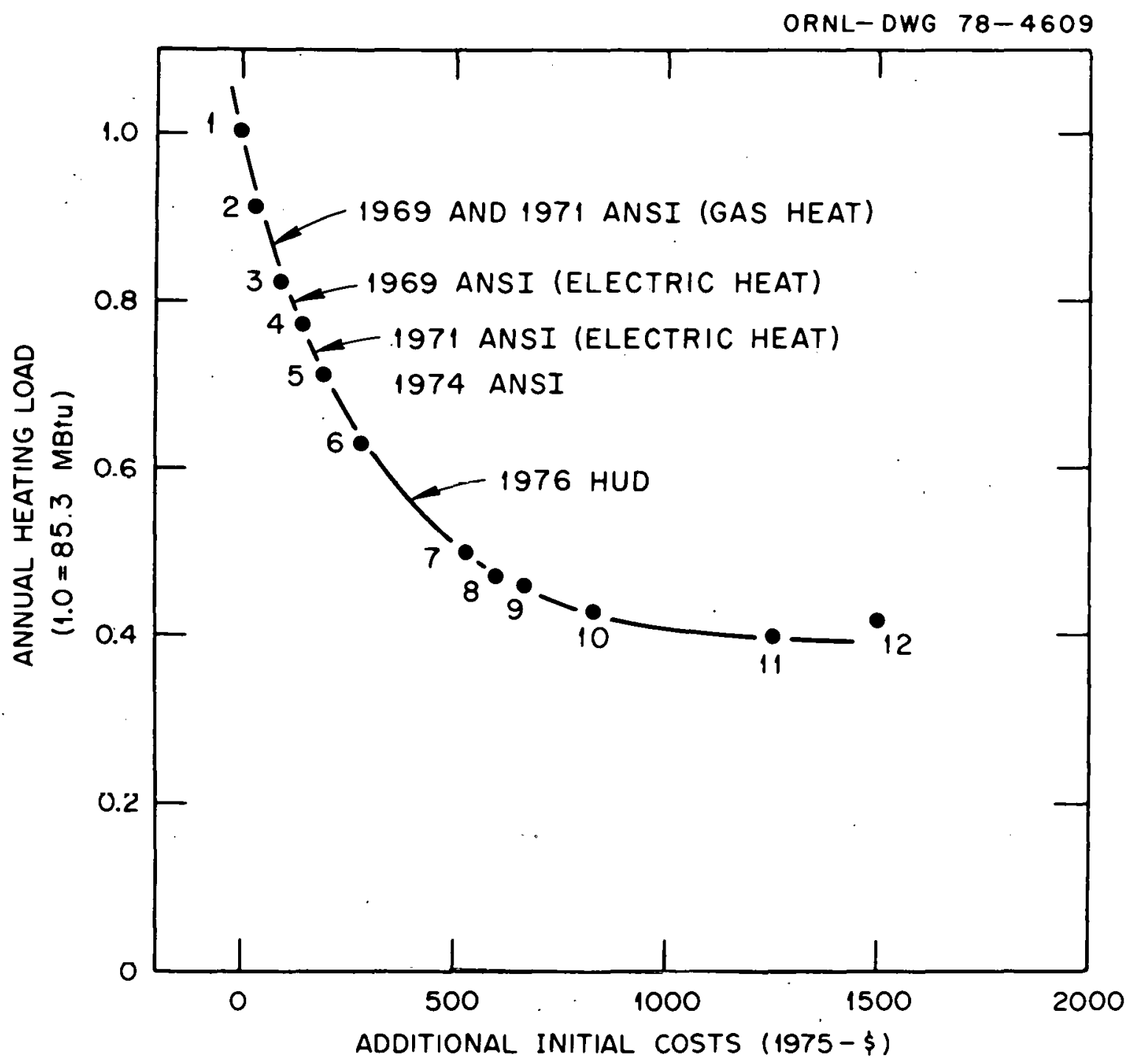

Figure C-5. Load/cost relationship - Kansas City. 


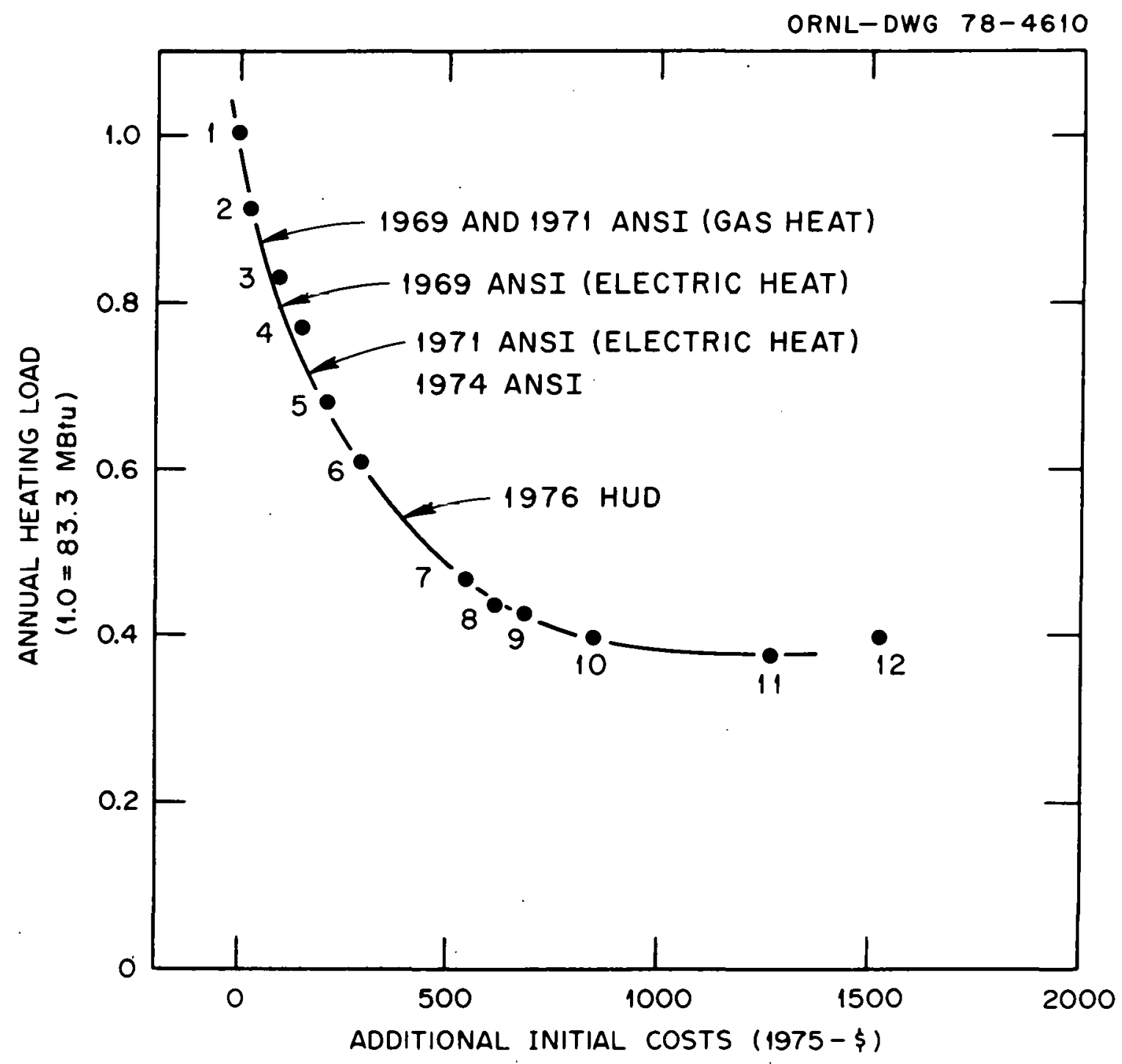

Figure C-6. Load/cost relationship - Washington, D.C. 


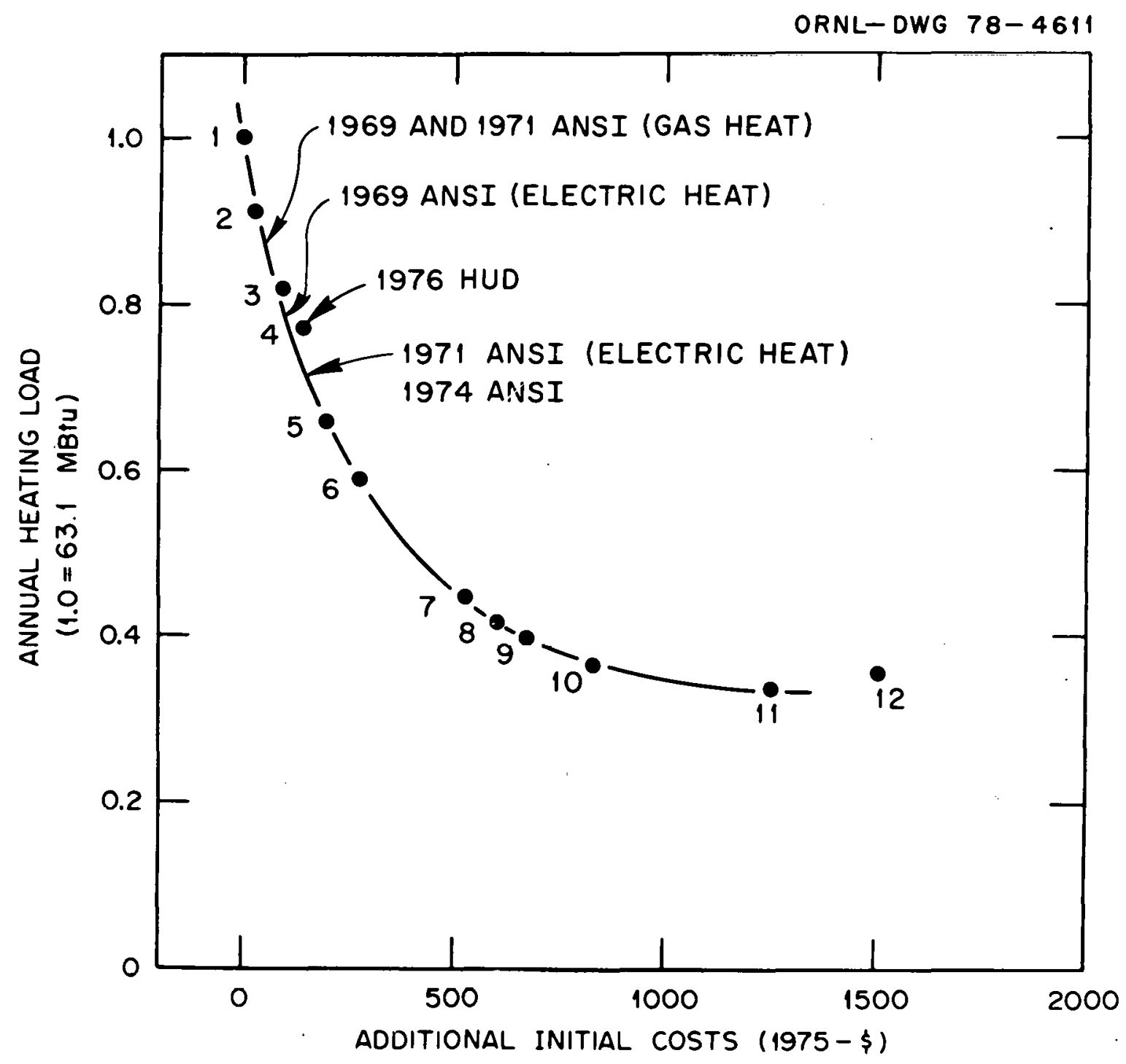

Figure C-7. Load/cost relationship - Atlanta. 


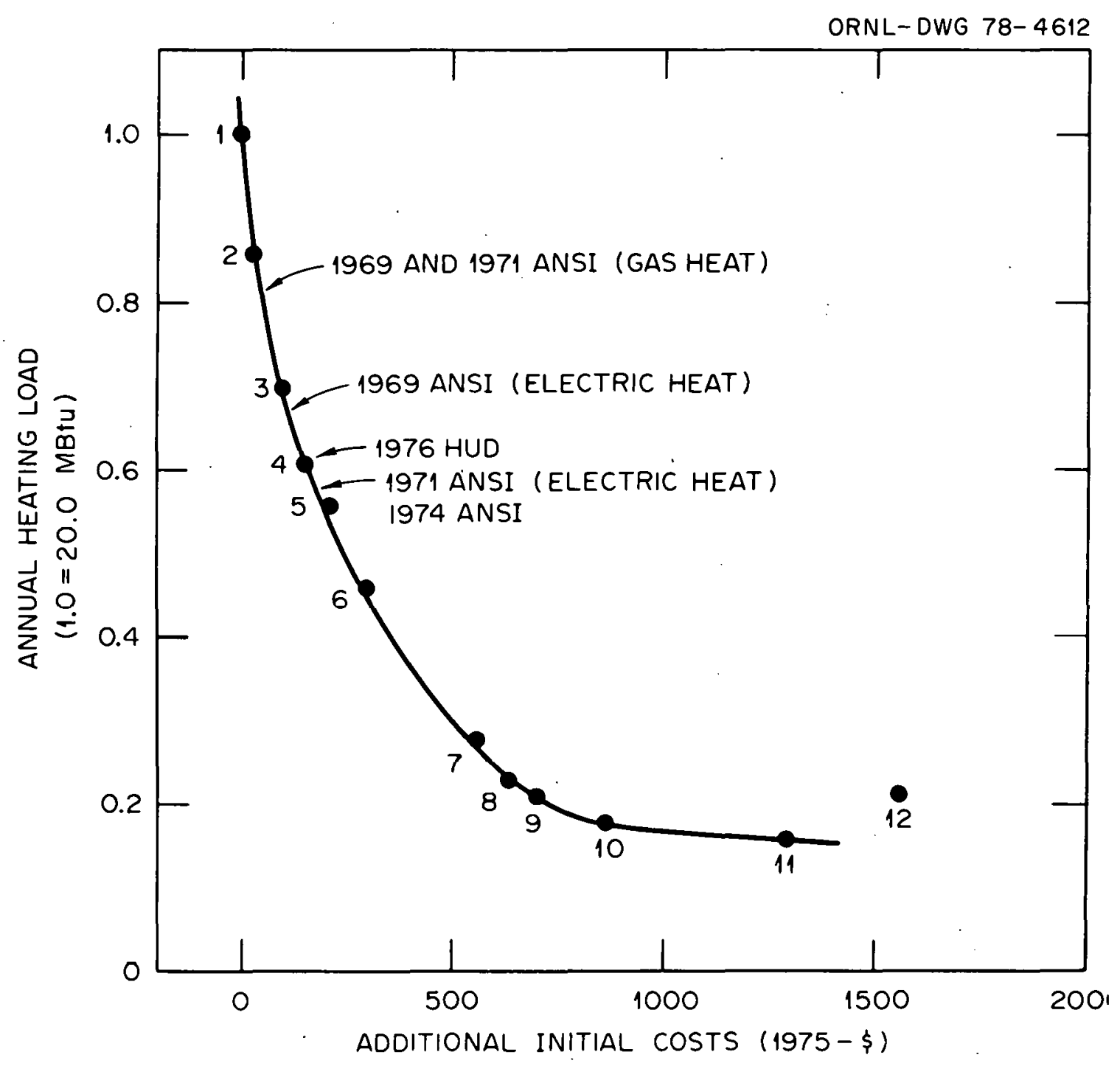

Figure C-8. Load/cost relationship - San Diego. 


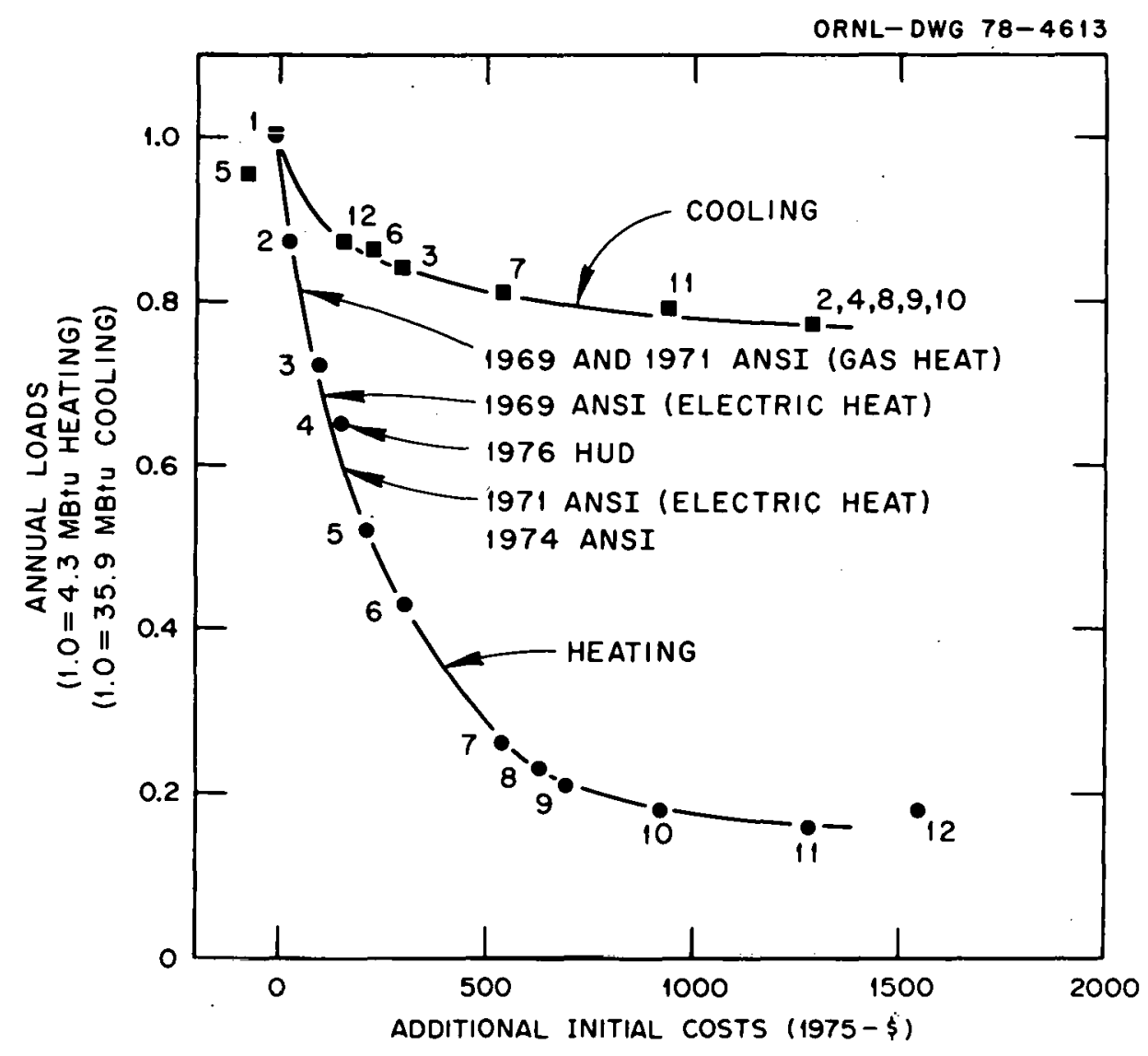

Figure C-9. Load/cost relationship - Miami. 


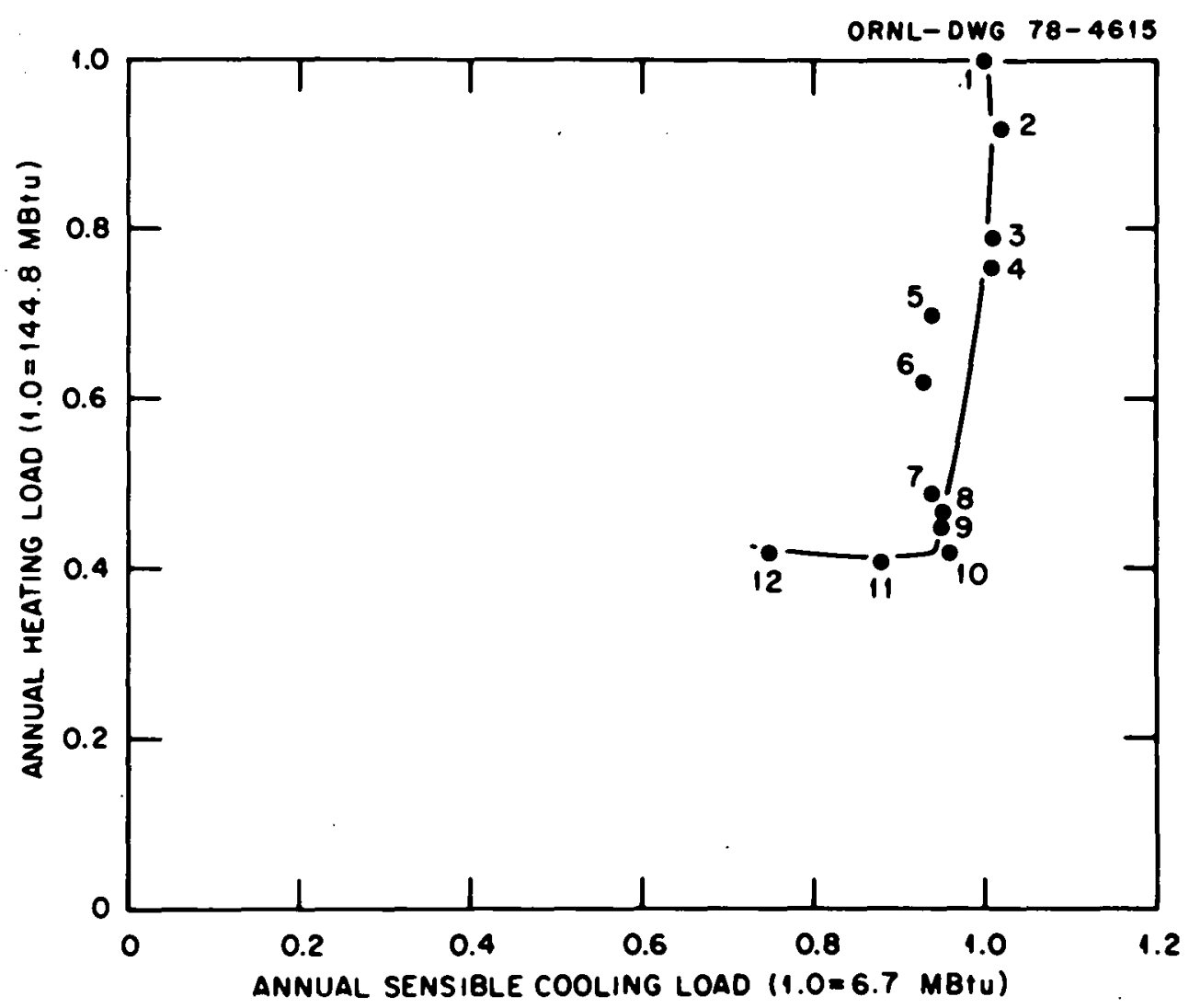

Figure C-10. Heating/cooling load relationship - Minneapolis. 


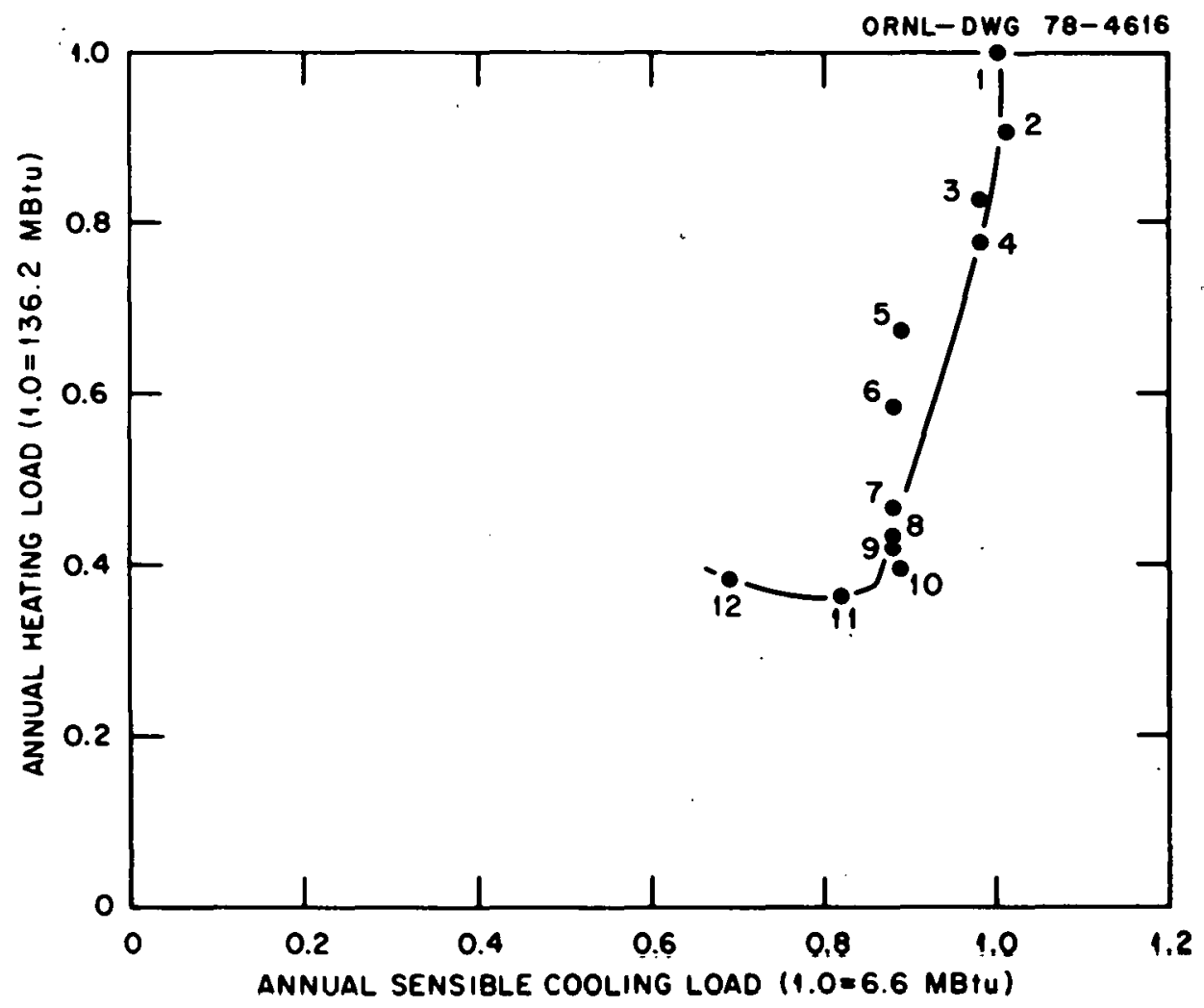

Figure C-11. Heating/cooling load relationship - Cheyenne. 


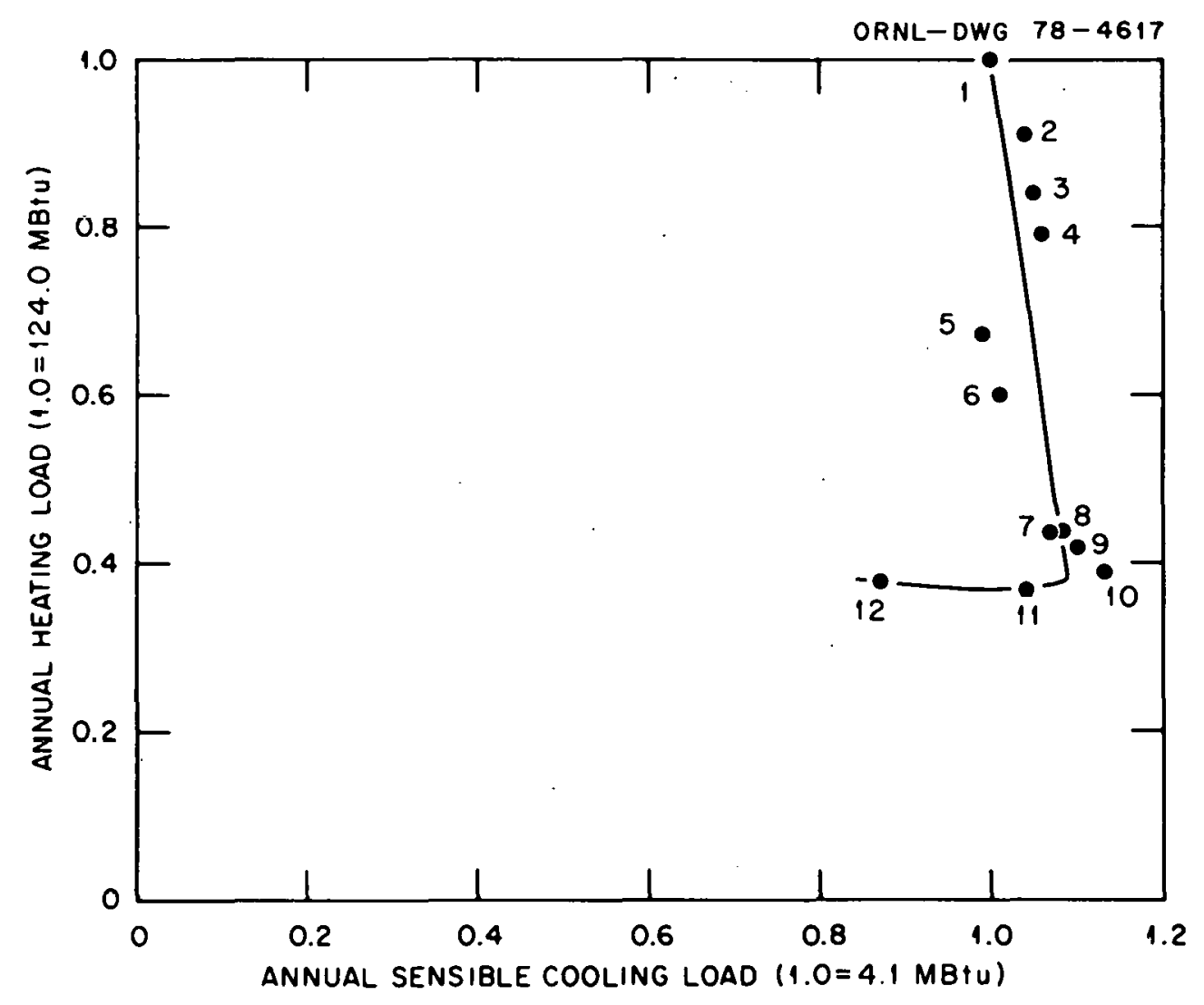

Figure C-12. Heating/cooling load relationship - Boston. 


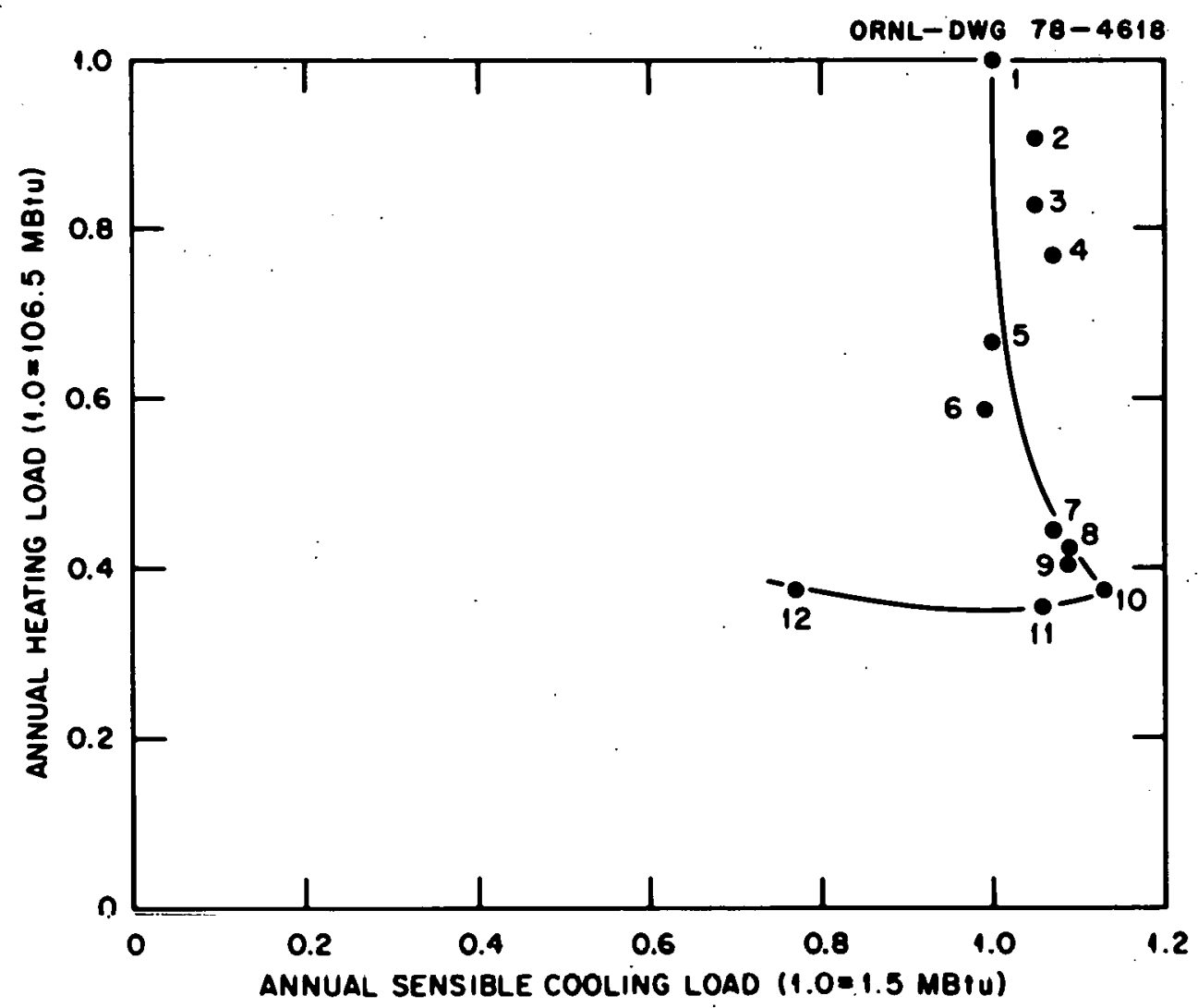

Figure C-13. Heating/cooling load relationship - Seattle. 


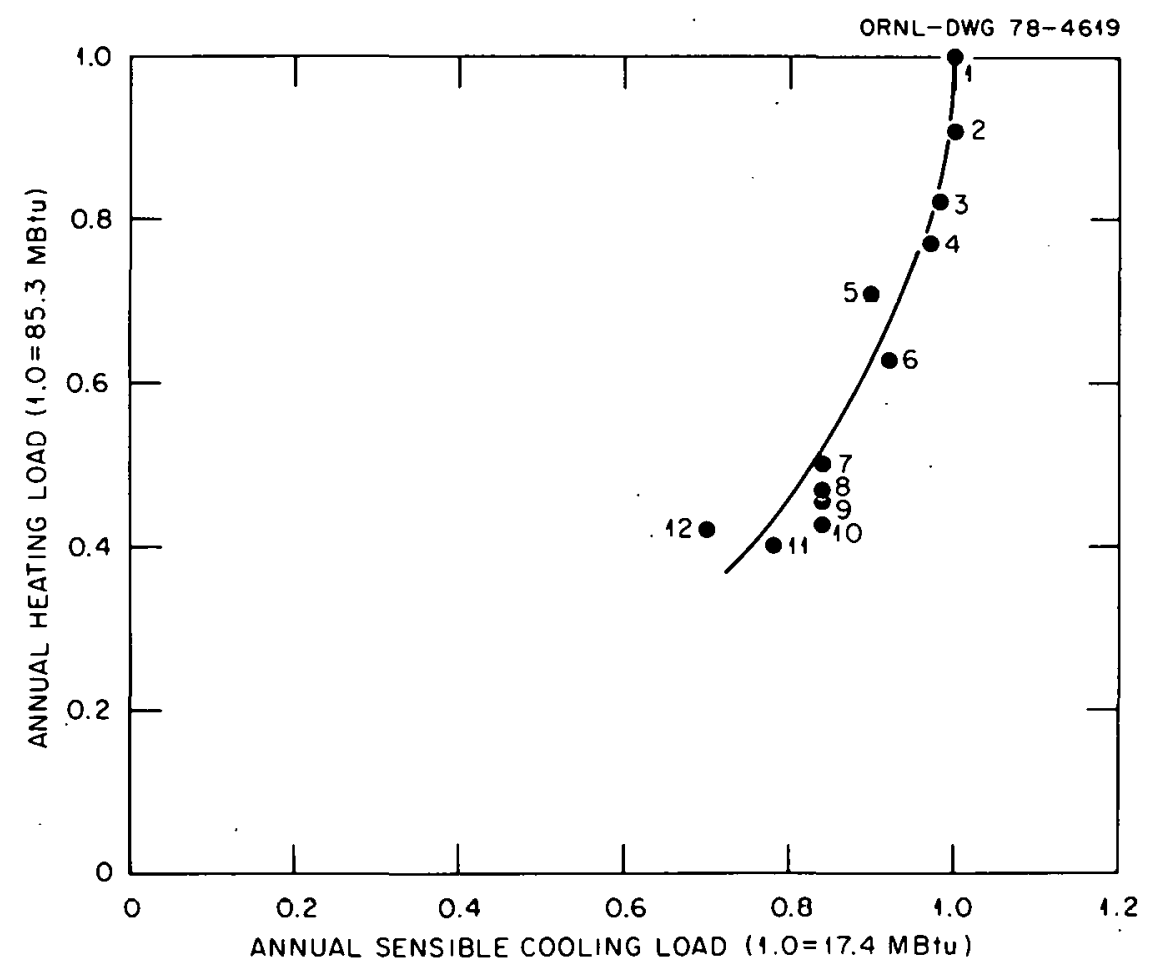

Figure C-14. Heating/cooling load relationship - Kansas City. 


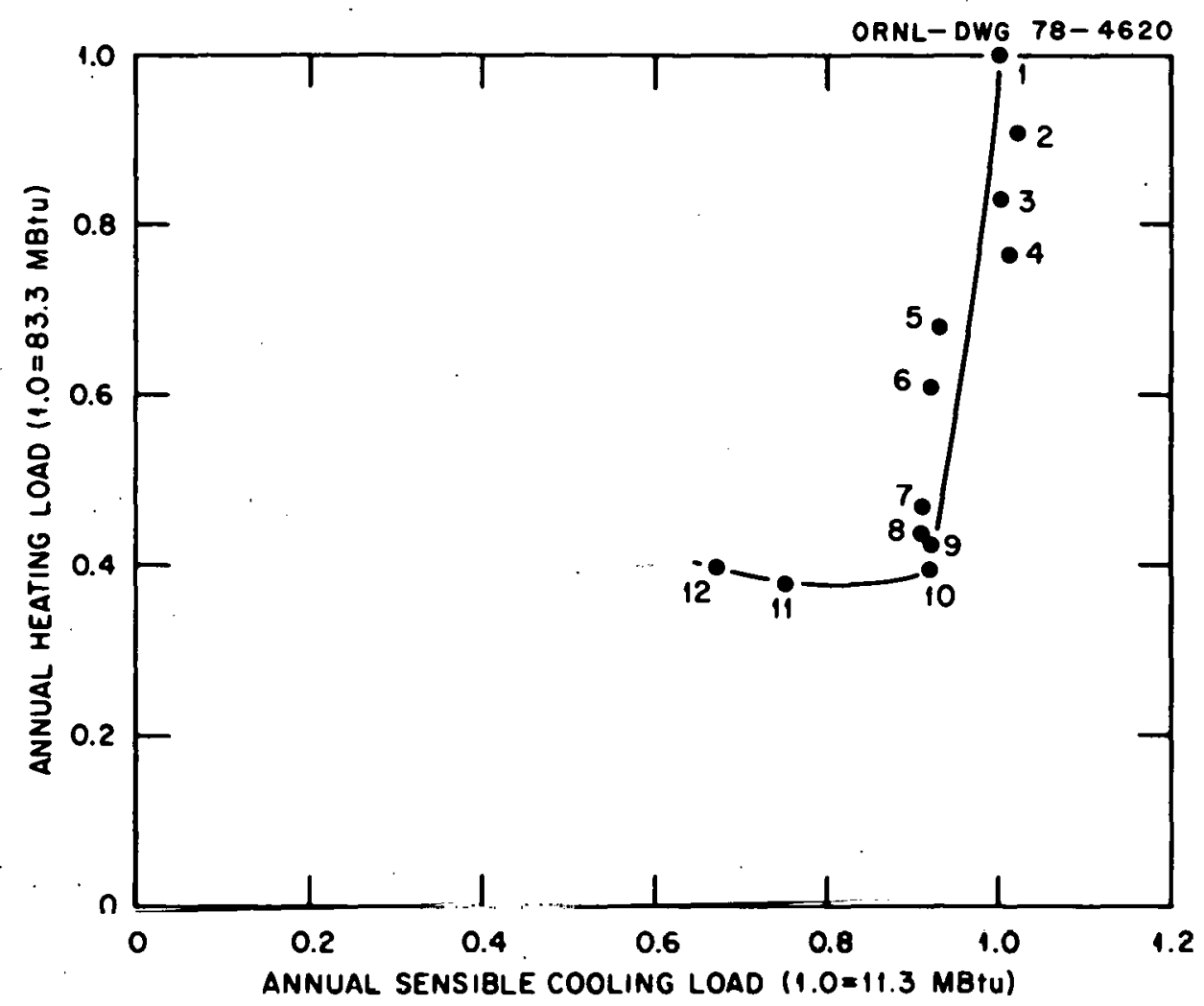

Figure C-15. Heating/cooling load relationship-Washington, D.C. 


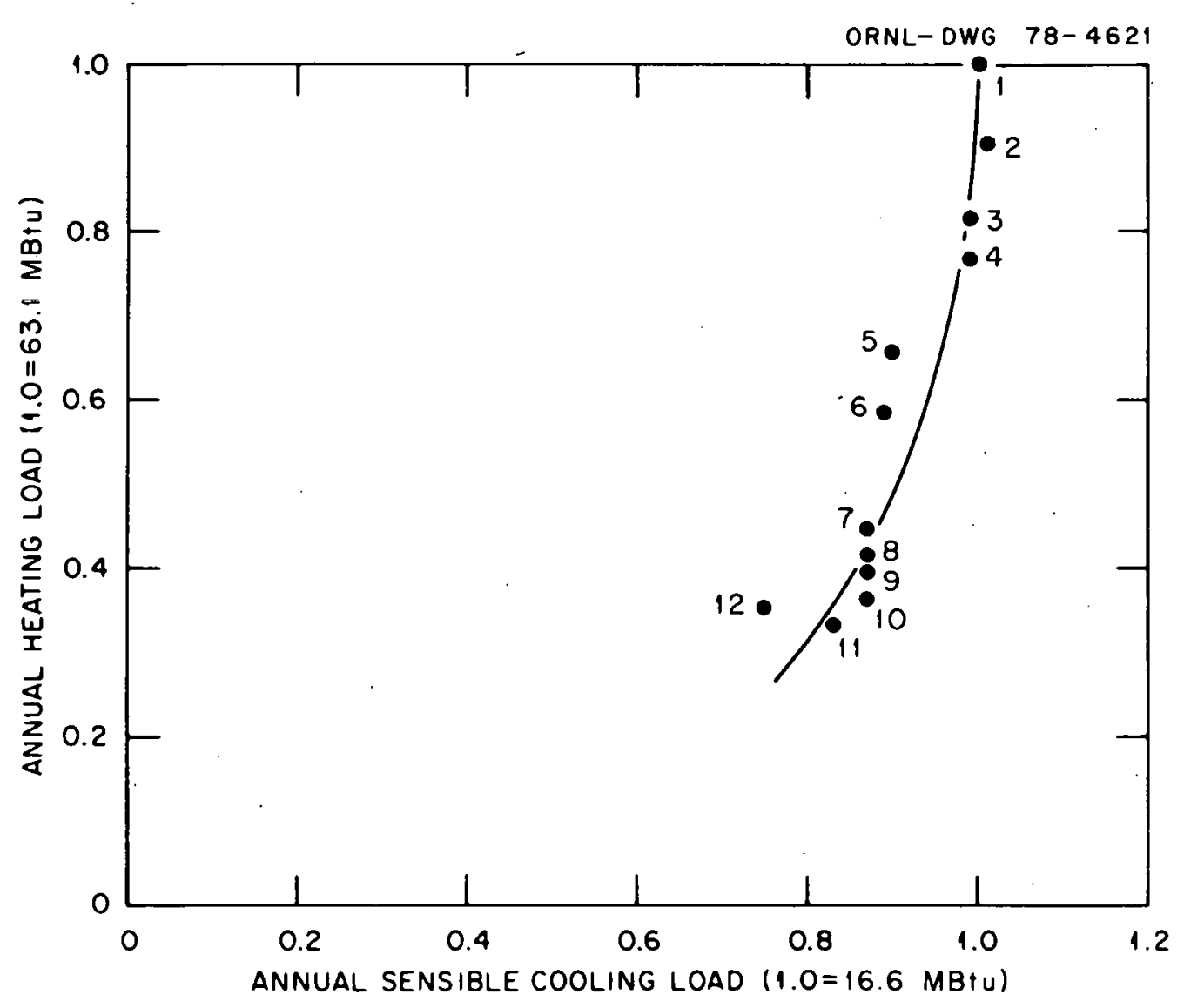

Figure C-16. Heating/cooling load relationship - Atlanta. 


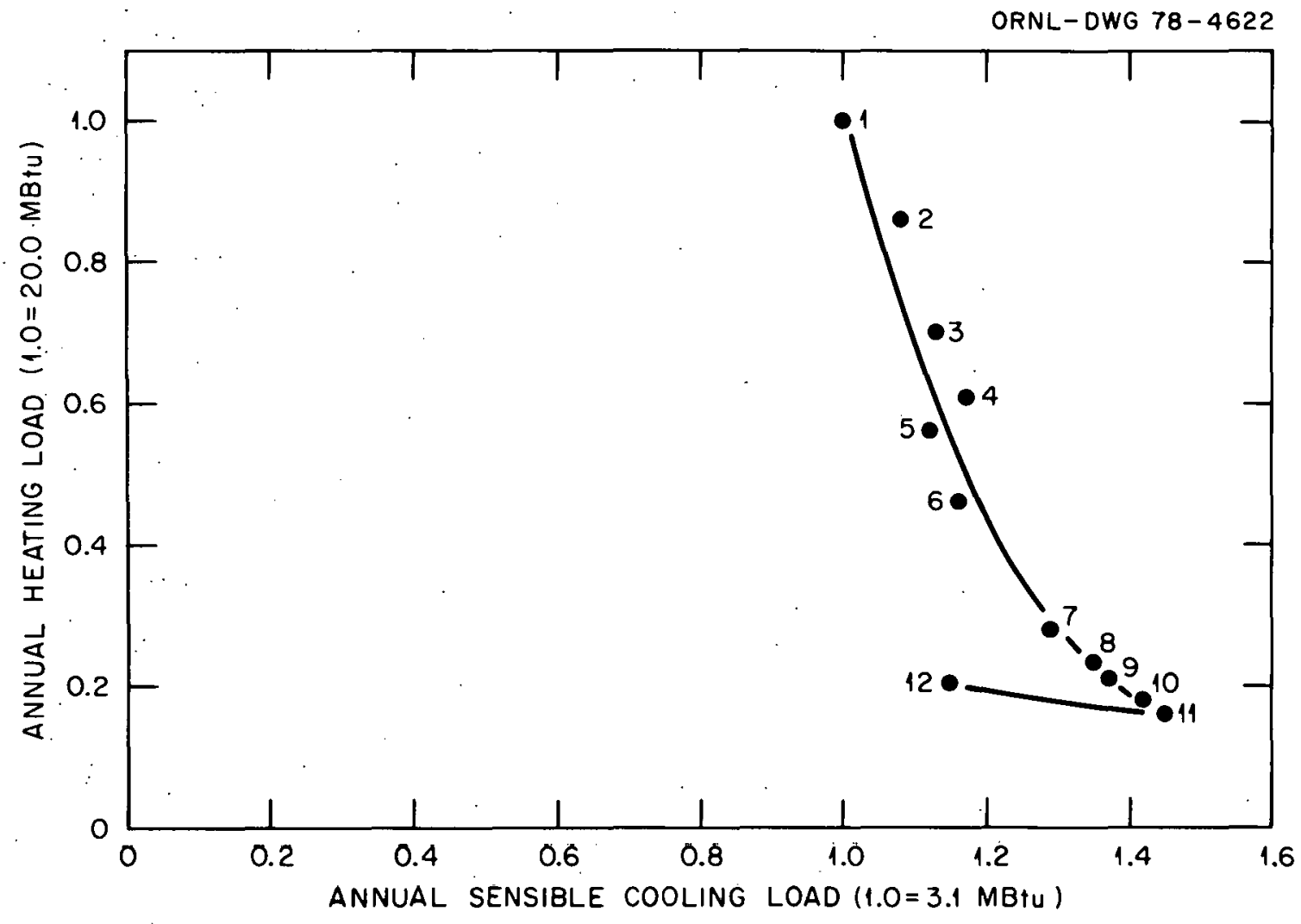

Figure C-17. Heating/cooling load relationship - San Diego. 


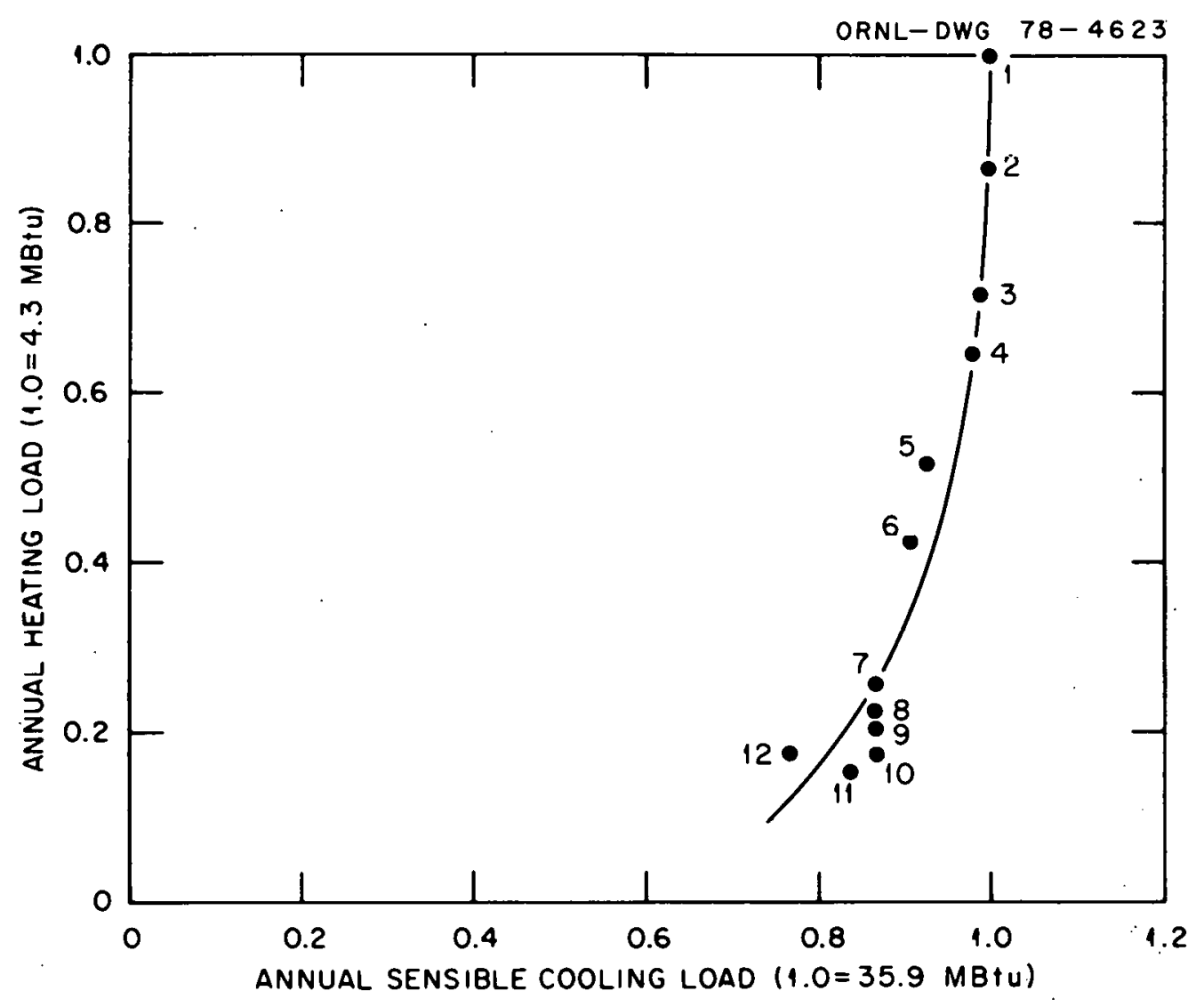

Figure C-18. Heating/cooling load relationșhip - Miami. 
TABLE $C-11$

ECONOMIC ANALYSIS RESULTS - MINNEAPOLIS

\begin{tabular}{|c|c|c|c|c|c|c|c|c|}
\hline \multirow[b]{3}{*}{$\begin{array}{l}\text { Design } \\
\text { Option }\end{array}$} & \multicolumn{4}{|c|}{ Natural Gas Heating } & \multicolumn{4}{|c|}{ Electric or LP Heating } \\
\hline & \multicolumn{2}{|c|}{ No $A / C^{*}$} & \multicolumn{2}{|c|}{ With $A / C^{*}$} & \multicolumn{2}{|c|}{ No $\mathrm{A} / \mathrm{C}^{*}$} & \multicolumn{2}{|c|}{ With $A / C^{*}$} \\
\hline & $\begin{array}{c}N P W^{* *} \\
(1975-\$)\end{array}$ & $\begin{array}{c}\mathrm{PB}^{* \star *} \\
\text { (years) }\end{array}$ & $\begin{array}{l}\text { NPW** } \\
(1975-\$)\end{array}$ & $\begin{array}{c}\mathrm{PB}^{\star \star \star} \\
\text { (years) }\end{array}$ & $\begin{array}{l}\text { NPW** } \\
(1975-\$)\end{array}$ & $\begin{array}{c}\mathrm{PB}^{* * *} \\
\text { (years) }\end{array}$ & $\begin{array}{l}N P W^{* *} \\
(1975-\$)\end{array}$ & $\begin{array}{c}\mathrm{PB}^{* * *} \\
\text { (years) }\end{array}$ \\
\hline 1 & 0. & 0.0 & 0 . & 0.0 & 0. & 0.0 & 0 . & 0.0 \\
\hline 2 & 329 . & 0.6 & 362 . & -0.2 & 1045 . & 0.2 & 1076 & -0.1 \\
\hline 3 & 800. & 0.9 & 861. & 0.4 & 2624 & 0.3 & 2682 & 0.1 \\
\hline 4 & 839 . & 1.3 & 915. & 0.7 & 2860. & 0.4 & 2933. & 0.2 \\
\hline 5 & 1024 . & 1.5 & 1207. & 0.4 & 3567. & 0.5 & 3745 & 0.2 \\
\hline 6 & 1305 . & 1.6 & 1511 . & 0.7 & 4608 & 0.5 & 4808 & 0.2 \\
\hline 7 & 1524 & 2.3 & 1765. & 1.5 & 5896. & 0.7 & 6128 & 0.5 \\
\hline 8 & 1539. & 2.5 & 1787. & 1.7 & 6127. & 0.8 . & 6366 & 0.5 \\
\hline 9 & 1529. & 2.7 & 1781 & 1.9 & 6267 & 0.9 & 6511. & 0.6 \\
\hline 10 & .1447 & 3.3 & 1706 & 2.4 & 6428. & 1.0 & 6679. & 0.8 \\
\hline 11 & 974. & 5.0 & 1257 & 4.1 & 6105 & 1.5 & 6379. & 1.3 \\
\hline 12 & 643. & 6.2 & 978 & 5.1 & 5689. & 1.9 & 6014 & 1.6 \\
\hline
\end{tabular}

TABLE $\mathrm{C}-12$

ECONOMIC ANALYSIS RESULTS - CHEYENNE

\begin{tabular}{|c|c|c|c|c|c|c|c|c|}
\hline \multirow[b]{3}{*}{$\begin{array}{l}\text { Design } \\
\text { Option }\end{array}$} & \multicolumn{4}{|c|}{ Natural Gas Heating } & \multicolumn{4}{|c|}{ Electric or LP Heating } \\
\hline & \multicolumn{2}{|c|}{ NO A/LA } & \multicolumn{2}{|c|}{ WIIn A/L" } & \multicolumn{2}{|c|}{ Nó $A / L^{\pi}$} & \multicolumn{2}{|c|}{ Wath $A / L^{\circ}$} \\
\hline & $\begin{array}{l}\mathrm{NPW}^{+4} \\
(1975-\$)\end{array}$ & $\begin{array}{c}\mathrm{PB}^{*+*} \\
\text { (years) }\end{array}$ & $\begin{array}{l}\text { NPW"* } \\
(1975-\$)\end{array}$ & $\begin{array}{c}P B^{*+t *} \\
\text { (years) }\end{array}$ & $\begin{array}{c}N P W^{*} * \\
(1975-\$)\end{array}$ & $\begin{array}{c}\text { PBkwk } \\
\text { (years) }\end{array}$ & $\begin{array}{c}\text { NPW'x } \\
(1975-\$)\end{array}$ & $\begin{array}{c}\mathrm{PB}^{\mathrm{AAd}} \\
\text { (ycars) }\end{array}$ \\
\hline 1 & 0 . & 0.0 & 0. & 0.0 & 0. & 0.0 & 0. & 0.0 \\
\hline 2 & 326. & 0.5 & 337 . & 0.2 & 1030. & 0.2 & 1041. & 0.1 \\
\hline 3 & 560. & 1.2 & 598. & 0.8 & 1905 & 0.4 & 1942. & 0.3 \\
\hline 4 & 707. & 1.5 & 759. & 1.1 & 2467. & 0.5 & 2518 & 0.3 \\
\hline 5 & 1039 & 1.5 & 1148. & 1.0 & 3617 & 0.5 & 3724 & 0.3 \\
\hline 6 & 1230 & 1.7 & 1358. & 1.2 & 4392. & 0.5 & 4516 & 0.4 \\
\hline 7 & 1472 . & 2.4 & 1610 & 2.0 & 5755 & 0.8 & 5890 & 0.6 \\
\hline 8 & 1484. & 2.6 & 1622. & 2.2 & 5977. & 0.8 & 6112. & 0.7 \\
\hline 9 & 1474 & 2.8 & 1612. & 2.4 & .6118. & 0.9 & 6252. & 0.8 \\
\hline 10 & 1387 & 3.4 & 1522. & 3.0 & 6268. & 1.1 & 6400. & 1.0 \\
\hline 11 & 952. & 5.1 & 1106. & 4.6 & 6060 & 1.6 & 6210. & 1.4 \\
\hline 12 & 615. & 6.3 & 810. & 5.7 & 5626. & 1.9 & 5817. & 1.8 \\
\hline
\end{tabular}

${ }^{*} \Lambda / C=$ air conditioning

$\star \star N P W=$ net present worth of savings

$* * * \mathrm{~PB}=$ payback period 
TABLE C -13

ECONOMIC ANALYSIS RESULTS - BOSTON

\begin{tabular}{|c|c|c|c|c|c|c|c|c|}
\hline \multirow[b]{3}{*}{$\begin{array}{l}\text { Design } \\
\text { Option }\end{array}$} & \multicolumn{4}{|c|}{ Natural Gas Heating } & \multicolumn{4}{|c|}{ Electric or LP Heating } \\
\hline & \multicolumn{2}{|c|}{ No $A / C^{*}$} & \multicolumn{2}{|c|}{ With $\mathrm{A} / \mathrm{C}^{*}$} & \multicolumn{2}{|c|}{ No $A / C^{*}$} & \multicolumn{2}{|c|}{ With $\mathrm{A} / \mathrm{C}^{*}$} \\
\hline & $\begin{array}{c}N P W^{* *} \\
(1975-\$)\end{array}$ & $\begin{array}{c}\mathrm{PB}^{\star \star \star *} \\
\text { (years) }\end{array}$ & $\begin{array}{l}N P W^{*} \\
(1975-\$)\end{array}$ & $\begin{array}{c}\mathrm{PB}^{* * *} \\
\text { (years) }\end{array}$ & $\begin{array}{c}N P W^{* *} \\
(1975-\$)\end{array}$ & $\begin{array}{c}\mathrm{PB}^{\star \star \star} \\
\text { (years) }\end{array}$ & $\begin{array}{l}N P W^{\star *} \\
(1975-\$)\end{array}$ & $\begin{array}{c}\mathrm{PB}^{\star \star \star} \\
\text { (years) }\end{array}$ \\
\hline 1 & 0. & 0.0 & 0. & 0.0 & 0 . & 0.0 & 0. & 0.0 \\
\hline 2 & 300. & 0.4 & 314. & -0.1 & 933. & 0.1 & 946. & -0.0 \\
\hline 3 & 488. & 1.3 & 514. & 0.8 & 1667. & 0.4 & 1692. & 0.3 \\
\hline 4 & 606. & 1.6 & 640. & 1.1 & 2142 . & 0.5 & 2175 . & 0.4 \\
\hline 5 & 986. & 1.5 & 1124. & 0.6 & 3434 . & 0.5 & 3568. & 0.2 \\
\hline 6 & 1149. & 1.7 & 1298. & 0.9 & 4115 . & 0.5 & 4259. & 0.3 \\
\hline 7 & 1410. & 2.4 & 1570. & 1.7 & 5522. & 0.8 & 5675. & 0.6 \\
\hline 8 & 1331. & 2.7 & 1493 & 2.1 & 5468. & 0.9 & 5625 & 0.7 \\
\hline 9 & 1308 & 3.0 & 1470 & 2.3 & 5573 & 0.9 & 5729 & 0.7 \\
\hline 10 & 1226 & 3.6 & 1389 & 2.9 & 5723. & 1.1 & 5879. & 0.9 \\
\hline 11 & 780 & 5.5 & 960 & 4.8 & 5479. & 1.7 & 5652 & 1.5 \\
\hline 12 & 443. & 6.8 & 653. & 6.0 & 5045 . & 2.0 & 5248 & 1.8 \\
\hline
\end{tabular}

${ }^{*} \mathrm{~A} / \mathrm{C}=$ air conditioning

$\star \star N P W=$ net present worth of savings

$\star \star * \mathrm{~PB}=$ payback period

TABLE C- 14

ECONOMIC ANALYSIS RESULTS - SEATTLE

\begin{tabular}{|c|c|c|c|c|c|c|c|c|}
\hline \multirow[b]{3}{*}{$\begin{array}{l}\text { Design } \\
\text { Option }\end{array}$} & \multicolumn{4}{|c|}{ Natural Gas Heating } & \multicolumn{4}{|c|}{ Electric or LP Heating } \\
\hline & \multicolumn{2}{|c|}{ No $A / C^{*}$} & \multicolumn{2}{|c|}{ With $\mathrm{A} / \mathrm{C}^{*}$} & \multicolumn{2}{|c|}{ No $A / C^{*}$} & \multicolumn{2}{|c|}{ With $A / C^{*}$} \\
\hline & $\begin{array}{c}N P W^{\star *} \\
(1975-\$)\end{array}$ & $\begin{array}{c}\mathrm{PB}^{* * *} \\
\text { (years) }\end{array}$ & $\begin{array}{c}N P W^{* *} \\
(1975-\$)\end{array}$ & $\begin{array}{c}\mathrm{PB}^{* \star \star} \\
\text { (years) }\end{array}$ & $\begin{array}{l}N P W^{* *} \\
(1975-\$)\end{array}$ & $\begin{array}{c}\mathrm{PB} * \star * \\
\text { (years) }\end{array}$ & $\begin{array}{l}N P W \star \star \\
(1975-\$)\end{array}$ & $\begin{array}{c}\mathrm{PB}^{\star \star \star} \\
\text { (years) }\end{array}$ \\
\hline 1 & 0 & 0.0 & 0. & 0.0 & 0 & 0.0 & 0 & 0.0 \\
\hline 2 & 258. & 0.8 & 273. & 0.3 & 832 . & 0.2 & 846. & 0.1 \\
\hline 3 & 430. & 1.6 & 461. & 1.1 & 1527. & 0.5 & 1557 & 0.4 \\
\hline 4 & 534 . & 1.9 & 576. & 1.4 & 1964. & 0.6 & 2005 & 0.5 \\
\hline 5 & 783. & 1.9 & 882. & 1.1 & 2866. & 0.6 & 2961. & 0.4 \\
\hline 6 & 922 . & 2.1 & 1037 & 1.4 & 3487 & 0.7 & 3598 & 0.5 \\
\hline 7 & 1056. & 3.0 & 1191. & 2.4 & 4530 & 1.0 & 4660 & 0.8 \\
\hline 8 & 1046 & 3.3 & 1183. & 2.7 & 4689 & 1.0 & 4821 & 0.8 \\
\hline 9 & 1023 & 3.6 & $1166:$ & 2.9 & 479.3. & 1.1 & 1931. & 0.0 \\
\hline 10 & 913 & 4.3 & 1060. & 3.6 & 4873. & 1.3 & 5015. & 1.1 \\
\hline 11 & 428 & 6.7 & 580 & 5.9 & 4514. & 2.0 & 1660 & 1.8 \\
\hline 12 & $B G$ & 8.4 & 256. & 7.5 & 4063. & 2.4 & 4228 & 2.2 \\
\hline
\end{tabular}

${ }^{\star} \mathrm{A} / \mathrm{C}=$ air conditioning

$\star \star N P W=$ net present worth of savings

***PB = payback period 
TABLE $C-15$

ECONOMIC ANALYSIS RESULTS - KANSAS CITY

\begin{tabular}{|c|c|c|c|c|c|c|c|c|}
\hline \multirow[b]{3}{*}{$\begin{array}{l}\text { Design } \\
\text { Option }\end{array}$} & \multicolumn{4}{|c|}{ Natural Gas Heating } & \multicolumn{4}{|c|}{ Electric or LP Heating } \\
\hline & \multicolumn{2}{|c|}{ No $A / C^{*}$} & \multicolumn{2}{|c|}{ With $\mathrm{A} / \mathrm{C}^{*}$} & \multicolumn{2}{|c|}{ No $A / C^{*}$} & \multicolumn{2}{|c|}{ With $A / C^{*}$} \\
\hline & $\begin{array}{l}\text { NPW** } \\
(1975-\$)\end{array}$ & $\begin{array}{c}\mathrm{PB} * * * \\
(\text { years) }\end{array}$ & $\begin{array}{c}N P W * * \\
(1975-\$)\end{array}$ & $\begin{array}{c}\mathrm{PB} * * * \\
\text { (years) }\end{array}$ & $\begin{array}{c}N P W^{* *} \\
(1975-\$)\end{array}$ & $\begin{array}{c}\mathrm{PB}^{\star \star \star *} \\
\text { (years) }\end{array}$ & $\begin{array}{l}\text { NPW** } \\
(1975-\$)\end{array}$ & $\begin{array}{l}\text { PB*** } \\
\text { (years) }\end{array}$ \\
\hline 1 & 0. & 0.0 & 0. & 0.0 & 0. & 0.0 & 0 & 0.0 \\
\hline 2 & 191. & 1.0 & 222. & 0.0 & 636. & 0.3 & 665. & 0.0 \\
\hline 3 & 329. & 2.0 & 401. & 1.0 & 1219 & 0.6 & 1289 & 0.3 \\
\hline 4 & 409 . & 2.3 & 507. & 1.2 & 1579 . & 0.7 & 1675 & 0.4 \\
\hline 5 & 493. & 2.6 & 718 . & 0.9 & 1985. & 0.8 & 2204 & 0.3 \\
\hline 6 & 577. & 2.9 & 841. & 1.3 & 2438 & 0.9 & 2697 & 0.5 \\
\hline 7 & $\underline{589 .}$ & 4.3 & 912. & 2.6 & 3112. & 1.3 & 3427 & 0.9 \\
\hline 8 & 571. & 4.6 & 908. & 2.9 & 3245 . & 1.4 & 3574 & 1.0 \\
\hline 9 & 534. & 5.0 & 875. & 3.3 & 3305 & 1.5 & 3638 & 1.1 \\
\hline 10 & 403. & 6.0 & 755 & 4.2 & 3323. & 1.8 & 3666. & 1.4 \\
\hline 11 & -63 & 9.3 & 340 . & 6.8 & 3018 . & 2.7 & 3412 . & 2.2 \\
\hline 12 & -388 & 11.9 & 79. & 8.4 & 2620. & 3.3 & 3078 & 2.7 \\
\hline
\end{tabular}

${ }^{\star} \mathrm{A} / \mathrm{C}=$ air conditioning

**NPW $=$ net present worth of savings

$\star \star \star \mathrm{PB}=$ payback period

TABLE C-16

ECONOMIC ANALYSIS RESULTS - WASHINGTON, D.C.

\begin{tabular}{|c|c|c|c|c|c|c|c|c|}
\hline \multirow[b]{3}{*}{$\begin{array}{l}\text { Design } \\
\text { Option }\end{array}$} & \multicolumn{4}{|c|}{ Natural Gas Heating } & \multicolumn{4}{|c|}{ Electric or LP Heating } \\
\hline & \multicolumn{2}{|c|}{ No $A / C^{*}$} & \multicolumn{2}{|c|}{ With $A / C^{*}$} & \multicolumn{2}{|c|}{ No $A / C^{*}$} & \multicolumn{2}{|c|}{ With $A / C^{*}$} \\
\hline & $\begin{array}{l}\text { NPW" } \\
\left(1975^{\prime}-\$\right)\end{array}$ & $\begin{array}{c}\mathrm{PB}^{* * *} \\
\text { (years) }\end{array}$ & $\begin{array}{l}N P W^{* *} \\
(1975-\$)\end{array}$ & $\begin{array}{c}\mathrm{PB}^{* * *} \\
\text { (years) }\end{array}$ & $\begin{array}{c}N \Gamma W^{* *} \\
(1975-\$)\end{array}$ & $\begin{array}{c}P B^{* * *} \\
\text { (years) }\end{array}$ & $\begin{array}{c}N P W^{*} \\
(1975-\$)\end{array}$ & $\begin{array}{c}\mathrm{PB}^{* * *} \\
\text { (years) }\end{array}$ \\
\hline 1 & 0. & 0.0 & 0. & 0.0 & 0 . & 0.0 & 0. & 0.0 \\
\hline 2 & 191. & 0.9 & 203. & 0.2 & 630. & 0.3 & 641. & 0.1 \\
\hline 3 & 312. & 2.0 & 346. & 1.4 & 1167. & 0.7 & 1200. & 0.5 \\
\hline 4 & 381. & 2.4 & 419. & 1.8 & 1498. & 0.8 & 1535. & 0.6 \\
\hline 5 & 533. & 2.5 & 739. & 0.7 & 2108 & 0.8 & 2308 . & 0.2 \\
\hline 6 & 617. & .2 .8 & 843. & 1.2 & 2561 . & 0.9 & 2781 . & 0.4 \\
\hline 7 & 638. & 4.1 & 897. & 2.0 & 3201 . & 1.3 & 3512 . & 0.8 \\
\hline 8 & 613. & 4.5 & 876. & 3.0 & 3375 . & 1.4 & 3631. & 1.0 \\
\hline 9 & 573 & 4.9 & 836. & 3.3 & 3426 & 1.5 & 3682 & 1.1 \\
\hline 10 & 442. & 5.9 & 717. & 4.3 & 3445 . & 1.8 & 3711. & 1.3 \\
\hline 11 & -63 & 9.3 & 294. & 7.0 & 3024 . & 2.7 & 3373 & 2.2 \\
\hline 12 & -391 & 11.9 & 11. & 8.8 & 2617. & 3.3 & 3010. & 2.7 \\
\hline
\end{tabular}

${ }^{*} A / C=$ air conditioning

$* * \mathrm{NPW}=$ net present worth of savings

$\star \star \star \mathrm{PB}=$ payback period 
TABLE $\mathrm{C}-17$

ECONOMIC ANALYSIS RESULTS - ATLANTA

\begin{tabular}{|c|c|c|c|c|c|c|c|c|}
\hline \multirow[b]{3}{*}{$\begin{array}{l}\text { Design } \\
\text { Option }\end{array}$} & \multicolumn{4}{|c|}{ Natural Gas Heating } & \multicolumn{4}{|c|}{ Electric or LP Heating } \\
\hline & \multicolumn{2}{|c|}{ No $A / C^{*}$} & \multicolumn{2}{|c|}{ With $\mathrm{A} / \mathrm{C}^{*}$} & \multicolumn{2}{|c|}{ No $A / C^{*}$} & \multicolumn{2}{|c|}{ With $A / C^{*}$} \\
\hline & $\begin{array}{c}N P W^{* *} \\
(1975-\$)\end{array}$ & $\begin{array}{c}p^{n * * *} \\
\text { Gearsj }\end{array}$ & $\begin{array}{c}N P W^{\star \star} \\
(1975-\$)\end{array}$ & $\begin{array}{c}P^{* * *} \\
\text { (years) }\end{array}$ & $\begin{array}{c}N P W^{* *} \\
(1975-\$)\end{array}$ & $\begin{array}{c}\mathrm{PB}^{* * *} \\
\text { (years) }\end{array}$ & $\begin{array}{l}N P W^{* *} \\
(1975-\$)\end{array}$ & $\begin{array}{c}\text { PB*** } \\
\text { (years) }\end{array}$ \\
\hline 1 & 0 & 0.0 & 0 & 0.0 & 0. & 0.0 & 0. & 0.0 \\
\hline 2 & 142 . & 1.3 & 162. & 0.2 & 486. & 0.4 & 505 . & 0.1 \\
\hline 3 & 219. & 2.7 & 272. & 1.5 & 891. & 0.9 & 942 . & 0.5 \\
\hline 4 & 260. & 3.2 & 331 & 1.9 & 1134. & 1.0 & 1203. & 0.6 \\
\hline 5 & 385 . & 3.1 & 583. & 1.3 & 1664 & 1.0 & 1858 & 0.5 \\
\hline 6 & 418. & 3.6 & 643. & 1.8 & 1967. & 1.1 & 2187 . & 0.6 \\
\hline 7 & 372. & 5.3 & 6.32. & 3.5 & 2463 & 1,6 & 2717 . & 1.2 \\
\hline 8 & 332. & 5.8 & 597. & 3.9 & 2533 & 1.7 & 2792 . & 1.3 \\
\hline 9 & 283. & 6.3 & 551. & 4.4 & 2558 . & 1.9 & 2820 . & 1.4 \\
\hline 10 & 135. & 7.7 & 411. & 5.6 & 2523 & 2.2 & 2793 & 1.8 \\
\hline 11 & -349 & 12.1 & -38 & 9.2 & 2164 & 3.3 & 2469 & 2.8 \\
\hline 12 & -671 & 15.8 & -308 & 11.4 & 1775 & 4.1 & 2132 . & 3.5 \\
\hline
\end{tabular}

${ }^{*} \mathrm{~A} / \mathrm{C}=$ air conditioning

$\star \star N P W=$ net present worth of savings

$\star \star \star \mathrm{PB}=$ payback period

TABLE $C-18$

ECONOMIC ANALYSIS RESULTS - SAN DIEGO

\begin{tabular}{|c|c|c|c|c|c|c|c|c|}
\hline \multirow[b]{3}{*}{$\begin{array}{l}\text { Design } \\
\text { Option }\end{array}$} & \multicolumn{4}{|c|}{ Natural Gas Heating } & \multicolumn{4}{|c|}{ Electric or LP Heating } \\
\hline & \multicolumn{2}{|c|}{ No $A / C^{*}$} & \multicolumn{2}{|c|}{ With $\mathrm{A} / \mathrm{C}^{*}$} & \multicolumn{2}{|c|}{ No $A / C^{*}$} & \multicolumn{2}{|c|}{ With $\mathrm{A} / \mathrm{C}^{*}$} \\
\hline & $\begin{array}{l}N P W^{*} \\
(1975-\$)\end{array}$ & $\begin{array}{c}\mathrm{PB}^{* * *} \\
\text { (years) }\end{array}$ & $\begin{array}{c}N P W^{\star *} \\
(1975-\$)\end{array}$ & $\begin{array}{c}\text { PB***} \\
\text { (years) }\end{array}$ & $\begin{array}{l}N P W^{* *} \\
(1975-\$)\end{array}$ & $\begin{array}{l}\mathrm{PB}^{* \star \star} \\
\text { (years) }\end{array}$ & $\begin{array}{l}N P W^{\star \star} \\
(1975-\$)\end{array}$ & $\begin{array}{c}\mathrm{PB}^{\star \star \star \star} \\
\text { (years) }\end{array}$ \\
\hline$\cdot 1$ & 0 . & 0.0 & 0 . & 0.0 & 0 . & 0.0 & 0 . & 0.0 \\
\hline$\underline{2}$ & 43. & 3.8 & 55. & 1.8 & 210 & 1.2 & 221. & 0.5 \\
\hline 3 & 47. & 6.2 & 77. & 4.1 & 406. & 1.9 & 435 . & 1.2 \\
\hline 4 & 33. & 7.4 & 78. & 5.1 & 495. & 2.2 & 538. & 1.4 \\
\hline 5 & -10 & 9.3 & 57. & 6.5 & 519. & 2.7 & 583. & 1.9 \\
\hline 6 & -58 & 10.9 & 28 . & 7.9 & 59.3. & 3.0 & 675. & 2.2 \\
\hline 7 & -277 & 17.0 & -175 & 14.2 & 600. & 4.4 & 698. & 3.5 \\
\hline 8 & -345 & 18.7 & -242 & 16.2 & 588. & 4.7 & 686. & 3.9 \\
\hline$y$ & -417 & 20.8 & -309 & 10.3 & 546. & 5.1 & 649. & 4.3 \\
\hline 10 & -607 & 27.3 & -499 & 25.5 & 399. & 6.1 & 501. & 5.4 \\
\hline 11 & -1133. & 50.9 & -1029 & 60.1 & $-B G$. & 0.5 & 12. & 8.8 \\
\hline 12 & -1438 & $\star \star \star \star *$ & -1285 & 85.9 & -423 & 12.1 & -276 & 11.0 \\
\hline
\end{tabular}

${ }^{*} \mathrm{~A} / \mathrm{C}=$ air conditioning

$* \star N P W=$ net present worth of savings

$\star \star * \mathrm{~PB}=$ payback period 
TABLE $\mathrm{C}-19$

ECONOMIC ANALYSIS RESULTS - MIAMI

\begin{tabular}{|c|c|c|c|c|c|c|c|c|}
\hline \multirow[b]{3}{*}{$\begin{array}{l}\text { Design } \\
\text { Option }\end{array}$} & \multicolumn{4}{|c|}{ Natural Gas Heating } & \multicolumn{4}{|c|}{ Electric or LP Heating } \\
\hline & \multicolumn{2}{|c|}{ No $A / C *$} & \multicolumn{2}{|c|}{ With $\mathrm{A} / \mathrm{C}^{*}$} & \multicolumn{2}{|c|}{ No $A / C^{*}$} & \multicolumn{2}{|c|}{ With $\mathrm{A} / \mathrm{C}^{*}$} \\
\hline & $\begin{array}{l}N P W^{* *} \\
(1975-\$)\end{array}$ & $\begin{array}{c}\mathrm{PB} * * * \\
\text { (years) }\end{array}$ & $\begin{array}{l}N P W^{* *} \\
(1975-\$)\end{array}$ & $\begin{array}{c}\mathrm{PB}^{* * *} \\
\text { (years) }\end{array}$ & $\begin{array}{l}N P W^{* *} \\
(1975-\$)\end{array}$ & $\begin{array}{c}\mathrm{PB}^{* * *} \\
\text { (years) }\end{array}$ & $\begin{array}{l}N P W^{* *} \\
(1975-\$)\end{array}$ & $\begin{array}{c}\mathrm{PB}^{* * *} \\
\text { (years) }\end{array}$ \\
\hline 1 & 0. & 0.0 & 0. & 0.0 & 0 . & 0.0 & 0. & 0.0 \\
\hline 2 & -21. & 26.8 & 16. & 0.5 & 14. & 6.1 & 49. & 0.2 \\
\hline 3 & -93 & 73.2 & -26 & 15.3 & -18 & 10.7 & 48. & 5.0 \\
\hline 4 & -147 & 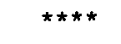 & -50 & 17.2 & -50 & 12.9 & 44. & 6.2 \\
\hline 5 & -206 & $\star \star \star \star$ & 110. & 2.8 & -73 & 13.2 & 236. & 1.5 \\
\hline 6 & -300 & $\star * * *$ & 73. & 5.5 & -140 & 16.3 & 224. & 3.1 \\
\hline 7 & -602 & $* * \star *$ & -143 & 14.7 & -388 & 27.4 & 62. & 7.6 \\
\hline 8 & -692 & $\star \star \star * *$ & -226 & 18.6 & -466 & 31.1 & -10 & 9.1 \\
\hline 9 & -775 & 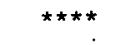 & -298 & 21.9 & -543 & 35.6 & -74 & 10.4 \\
\hline 10 & -977 & $\star \star * * *$ & -483 & 33.7 & -730 & 48.8 & -246 & 14.2 \\
\hline 11 & -1512 & $\star * \star \star \star$ & -970 & 75.9 & -1240 & $\star \star \star \star \star *$ & -709 & 25.0 \\
\hline 12 & -1798 & $\star \star \star \star *$ & -1138. & 63.2 & -1521. & $\star \star \star \star \star$ & -872 & 26.0 \\
\hline
\end{tabular}

${ }^{*} \mathrm{~A} / \mathrm{C}=$ air conditioning

$\star \star \mathrm{NPW}=$ net present worth of savings

$\star \star \star \mathrm{PB}=$ payback period

TABLE $\mathrm{C}-20$

ECONOMIC ANALYSIS RESULTS - MIAMI (Cooling)

\begin{tabular}{|c|c|c|c|c|c|c|c|c|}
\hline \multirow[b]{3}{*}{$\begin{array}{l}\text { Design } \\
\text { Option }\end{array}$} & \multicolumn{4}{|c|}{ Natural Gas Heating } & \multicolumn{4}{|c|}{ Electric or LP Heating } \\
\hline & \multicolumn{2}{|c|}{$\mathrm{A} / \mathrm{C}^{*}$ On $1 \mathrm{y}$} & \multicolumn{2}{|c|}{ With Heat } & \multicolumn{2}{|c|}{$\mathrm{A} / \mathrm{C}^{\star}$ On $1 \mathrm{y}$} & \multicolumn{2}{|c|}{ With Heat } \\
\hline & $\begin{array}{c}N P W^{* *} \\
(1975-\$)\end{array}$ & $\begin{array}{l}\text { PB*k* } \\
\text { (years) }\end{array}$ & $\begin{array}{l}N P W^{\alpha} \\
(1975-\$)\end{array}$ & $\begin{array}{l}P B \wedge \& A \\
\text { (years) }\end{array}$ & $\begin{array}{c}N P W^{\star \star} \\
(1975-\$)\end{array}$ & $\begin{array}{c}\mathrm{PB}^{\star \star \star} \\
\text { (years) }\end{array}$ & $\begin{array}{c}N P W^{*} \\
(1975-\$)\end{array}$ & $\begin{array}{c}\mathrm{PB}^{* * \star} \\
\text { (years) }\end{array}$ \\
\hline 1 & 0. & 0.0 & 0 & 0.0 & 0 . & 0.0 & 0. & 0.0 \\
\hline 5 & 2. & 8.4 & 113. & -1.7 & 111. & 2.4 & 219. & -0.8 \\
\hline 12 & -357 & 72.9 & -267 & 37.3 & -68 & 10.6 & 20. & 8.4 \\
\hline 6 & -445 & 90.1 & -288 & 30.7 & -116 & 11.6 & $3 \%$ & 8.1 \\
\hline 3 & -529 & $* * * *$ & -322 & 29.3 & -17.3 & 12.7 & 28. & 8.4 \\
\hline 7 & -814 & $\star \star \star \star *$ & -501 & 33.6 & -365 & 15.6 & -58 & 9.7 \\
\hline 11 & -1328 & $\star \star \star * *$ & -971 & 80.3 & -818 & 24.5 & -469 & 15.5 \\
\hline 12 & -1386 & 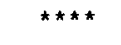 & -1001 & 66.0 & -832 & 23.2 & $-4 S S$ & 14.6 \\
\hline 4 & -1430 & $\star \star \star \star *$ & -1045 & 71.6 & -875 & 24.1 & -498 & 15.2 \\
\hline 8 & -1497 & $\star * \star *$ & -1112. & 81.4 & -940 & 25.5 & -562 & 16.1 \\
\hline 9 & -1593 & $\star \star \star \star \star$ & -1208. & 98.8 & -1032 & 27.7 & -655 & 17.5 \\
\hline 10 & -1800 & $\star \star \star \star$ & -1414 & $\star \star \star \star \star$ & -1232 & 32.8 & -854 & 20.6 \\
\hline
\end{tabular}

${ }^{*} \mathrm{~A} / \mathrm{C}=$ air conditioning

$\star \star N P W=$ net present worth of savings

$\star \star \star \mathrm{PB}=$ payback period 
APPENDIX D

DESIGN LOAD CALCULATIONS FOR MOBILE HOME THERMAL STANDARDS 1969 TO PRESENT 
THIS PAGE

WAS INTENTIONALLY

LEFT BLANK 
The following contains hand calculations for the design load conditions to determine the levels of insulation and other energyefficient design necessary to meet the 1969,1971 (for gas and electric heating fuels), and 1974 ANSI standards plus 1976 HUD standard. The calculations are constructed to closely represent those made by mobile home manufacturing personnel when designing to meet the given standard. Worksheets used were obtained from NFPA \#501BM. ${ }^{12}$ The heat loss worksheets for the calculations are contained in Figures D-1 through D-8 with a summary of the actual designs to standards in Table D-1. The mobile home dimensions used are consistent with those discussed in Section II of the main body of the text. 
HEAT LOSS WORKSHEET

\section{Heat Loss of Home}

Min. R-values:

$\mathrm{R} \geq 5.5^{\text {Walls }}=\frac{\mathrm{sq} \mathrm{ft}}{\mathrm{R}_{\mathrm{f}} \text { of walls }}=\frac{1079}{-6.5}=\underline{166}$

$\mathrm{R} \geq 8.2$ Ceilings $=\frac{\mathrm{sq} f t}{\mathrm{R}_{\mathrm{f}} \text { of ceiling }}=\frac{952}{9.9}=\underline{96}$

$R \geq 5.5^{\text {Floors }}=\frac{\text { sq } f t}{R_{f} \text { of floor }}=\frac{952}{7.2}=\underline{132}$

$$
\text { Windows }=\frac{\mathrm{sq} f \mathrm{ft}}{\mathrm{R} \text { of windows }}=\frac{117}{0.88}=\underline{133}
$$$$
\text { Doors }=\frac{\mathrm{sq} \mathrm{ft}}{\mathrm{R} \text { of doors }} \quad=\frac{34}{1.85}=\frac{18}{545}
$$

Infiltration*

$111=\underline{111}$

TOTAL $=\underline{656}\left(\mathrm{Btuh} /{ }^{\circ} \mathrm{F}\right)$

Calculation of Minimum Design Temperature

The greater of:

$50 \mathrm{Btuh} / \mathrm{sq} \mathrm{ft} \times \underline{952} \mathrm{sq} \mathrm{ft}=\frac{47600}{(\mathrm{Btuh}) /{ }^{\circ} \mathrm{F}}=\frac{47600}{656}=\underline{73^{\circ} \mathrm{F}}(\mathrm{TD} \max )$, and

('69) 375 Btuh/1in $\mathrm{ft} \times \underline{164}$ lin $\mathrm{ft}=\frac{61500}{(\mathrm{Bt.uh}) /{ }^{\circ} \mathrm{F}}=\frac{61500}{656}=94^{\circ} \mathrm{F}(\mathrm{TD} \max$.$) ,$

('71) $333 \mathrm{Btuh} / 1$ in $\mathrm{ft} \times \underline{164}$ in $\mathrm{ft} \stackrel{\text { or }}{=} \frac{54612}{(\mathrm{Btuh}) /{ }^{\circ} \mathrm{F}}=\frac{54612}{656}=\underline{83^{\circ} \mathrm{F}}(\mathrm{TD} \max$.

Minimum Outdoor Design Temperature

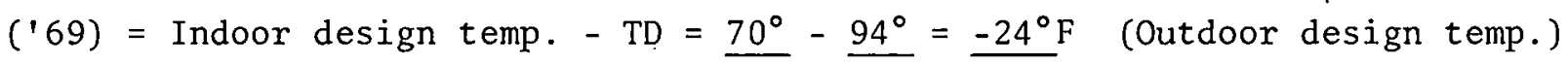

$\left({ }^{\prime} 71\right)=$ Indoor deśign temp. $-\mathrm{TD}=70^{\circ}-83^{\circ}=-13^{\circ} \mathrm{F}$ (Outdoor design temp.)

*111 $\times$ TD method per NFPA 501B:

Figure D-1. Heat loss worksheet for 1969 and 1971 ANSI standards for gas-heated mobile home. ${ }^{7}$ 
Heat Loss of Home

Min. R-values:

Heat Loss

$\left(\mathrm{Btuh} /{ }^{\circ} \mathrm{F}\right)$

$$
\begin{aligned}
& \mathrm{R} \geq 6.5^{\text {Walls }}=\frac{\mathrm{sq} \mathrm{ft}}{\mathrm{R}_{\mathrm{f}} \text { of walls }} \quad=\frac{1079}{6.5}=\underline{166^{\circ}} \\
& \mathrm{R} \geq 13=\frac{\mathrm{sq} \mathrm{ft}}{\mathrm{R}_{\mathrm{f}} \text { of ceiling }}=\frac{952}{13.6}=\underline{70} \\
& R \geq 12^{\text {Floors }}=\frac{\mathrm{sq} f t}{\mathrm{R}_{\mathrm{f}} \text { of floox }}=\frac{952}{14.1}=\underline{68} \\
& \text { Windows }=\frac{\mathrm{sq} \mathrm{ft}}{\mathrm{R} \text { of windows }}=\frac{117}{0.88}=\underline{133} \\
& \text { Doors }=\frac{\mathrm{sq} \mathrm{ft}}{\mathrm{R} \text { of doors }}=\frac{34}{1.85}=\frac{18}{455} \\
& \text { Infiltration* } \quad 111 . \underline{111} \\
& \text { TOTAL }=\underline{566}\left(\mathrm{Btuh} /{ }^{\circ} \mathrm{F}\right)
\end{aligned}
$$

Calculation of Minimum Design Temperature

The smaller of:

$40 \mathrm{Btuh} / \mathrm{sq} \mathrm{ft} \quad \times \underline{952} \mathrm{sq} f t=\frac{38080}{(\mathrm{Btuh}) /{ }^{\circ} \mathrm{F}}=\frac{38080}{566}=\underline{67^{\circ} \mathrm{F}}(\mathrm{TD} \max$.

$0.628 \mathrm{Btuh} / \mathrm{sq} \mathrm{ft}-{ }^{\circ} \mathrm{F} \times \underline{952} \mathrm{sq} \mathrm{ft}=\frac{598 \times 70^{\circ} \mathrm{F}}{(\mathrm{Btuh}) /{ }^{\circ} \mathrm{F}}=\frac{41860}{566}=\underline{74^{\circ} \mathrm{F}}(\mathrm{TD} \max$.

Minimum Outdoor Design Temperature

$=$ Indoor design temp. $-\mathrm{TD}=70^{\circ}-\underline{67^{\circ}}=\underline{3^{\circ} \mathrm{F}}$ (Outdoor design temp.)

*111 × TD method per NFPA 501B

Figure D-2. Heat loss worksheet for 1969 ANSI standard for electrically heated mobile home (all but Cheyenne and Minneapolis). ${ }^{7}$ 
HEAT LOSS WORKSHEET

Heat Loss of Home

Min. R-values:

Heat Loss

$\left(\right.$ Btuh $\left./{ }^{\circ} \mathrm{F}\right)$

$\mathrm{R} \geq 6.5^{\text {Walls }}=\frac{\mathrm{sq} f \mathrm{t}}{\mathrm{R}_{\mathrm{f}} \text { of walls }} \quad=\frac{1079}{9.7}=\underline{111}$

$\mathrm{R} \geq 13 \stackrel{\text { Ceilings }}{=} \frac{\mathrm{sq} f t}{\mathrm{R}_{\mathrm{f}} \text { of ceiling }}=\frac{952}{13.6}=\underline{70}$

$\mathrm{R} \geq 12^{\text {Floors }}=\frac{\mathrm{sq} \mathrm{ft}}{\mathrm{R}_{\mathrm{f}} \text { of floor }}=\frac{952}{14.1}=\underline{68}$

$$
=\frac{\mathrm{sq} f \mathrm{t}}{\mathrm{R} \text { of windows }}=\frac{117}{0.88}=\underline{133}
$$$$
\text { Doors }=\frac{\text { sq ft }}{\mathrm{R} \text { of doors }} \quad=\frac{34}{1.85}=\frac{18}{400}
$$

Infiltration* $\quad 111 \quad=\underline{111}$

TOTAL $=\underline{511}\left(\mathrm{Btuh} /{ }^{\circ} \mathrm{F}\right)$

\section{Calculation of Minimum Design Temperature}

The smaller of:

$40 \mathrm{Btuh} / \mathrm{sq} \mathrm{ft} \quad \times \underline{952} \mathrm{sq} \mathrm{ft}=\frac{38080}{(\mathrm{Btuh}) /{ }^{\circ} \mathrm{F}}=\frac{38080}{511}=\underline{75^{\circ} \mathrm{F}}$ ('TD $\left.\max .\right)$

$0.628 \mathrm{Btuh} / \mathrm{sq} \mathrm{ft}-{ }^{\circ} \mathrm{F} \times \underline{952} \mathrm{sq} \mathrm{ft}=\frac{598 \times 70^{\circ} \mathrm{F}}{(\mathrm{Btuh}) /{ }^{\circ} \mathrm{F}}=\frac{41860}{511}=\underline{82^{\circ} \mathrm{F}}(\mathrm{TD} \max$.

Minimum Outdoor Design 'T'emperature

$=$ Indoor design temp. $-\mathrm{TD}=\underline{70^{\circ}}-\underline{75^{\circ}}=\underline{-5^{\circ} \mathrm{F}}$ (Outdoor design temp.)

*111 $\times$ TD method per NFPA 501B.

Figure D-3. Heat loss worksheet for 1969 ANSI standard for electrically heated mobile home - Cheyenne.? 
Heat Loss of Home

Min. R-values:

Heat Loss

(Btuh $/{ }^{\circ} \mathrm{F}$ )
$R \geq 6.5^{\text {Walls }}=\frac{\mathrm{sq} \mathrm{ft}}{\mathrm{R}_{\mathrm{f}} \text { of walls }}$
$=\frac{1079}{9.7}=111$
$R \geq 13^{\text {Ceilings }}=\frac{\text { sq ft }}{\mathrm{R}_{\mathrm{f}} \text { of ceiling }}$
$=\frac{952}{13.6}=\underline{70}$
$\mathrm{R} \geq 12$
Floors $=\frac{\text { sq ft }}{R_{f} \text { of floor }}$
$=\frac{952}{14.1}=\underline{68}$
Windows $=\frac{\text { sq } f t}{\mathrm{R} \text { of windows }}$
$=\frac{117}{1.79}=\underline{65}$ (storms)$$
\text { Doors }=\frac{\mathrm{sq} \mathrm{ft}}{\mathrm{R} \text { of doors }}
$$
$=\frac{34}{1.85}=\frac{18}{332}$
Infiltration*
111
$=111$
TOTAL $=\underline{443}\left(\right.$ Btuh $\left./{ }^{\circ} \mathrm{F}\right)$

Calculation of Minimum Design Temperature

The smaller of:

$$
\begin{aligned}
40 \mathrm{Btuh} / \mathrm{sq} \mathrm{ft} & \times \underline{952} \mathrm{sq} \mathrm{ft}=\frac{38080}{(\mathrm{Btuh}) /{ }^{\circ} \mathrm{F}}=\frac{38080}{443}=86^{\circ} \mathrm{F}(\mathrm{TD} \max .) \\
0.628 \mathrm{Btuh} / \mathrm{sq} \mathrm{ft}-{ }^{\circ} \mathrm{F} & \times \underline{952} \mathrm{sq} \mathrm{ft}=\frac{598 \times 70^{\circ} \mathrm{F}}{(\mathrm{Btuh}) /{ }^{\circ} \mathrm{F}}=\frac{41800}{443}=94^{\circ} \mathrm{F}(\mathrm{TD} \max .)
\end{aligned}
$$

Minimum Outdoor Design Temperature

= Indoor design temp. $-\mathrm{TD}=\underline{70^{\circ}}-\underline{86^{\circ}}=\underline{-16^{\circ} \mathrm{F}}$ (Outdoor design temp.)

*111 x Tn method per NFPA SỦiB.

Figure D-4. Heat loss worksheet for 1969 ANSI standard for electrically heated mobile home - Minneapoli.s.? 


\section{HEAT LOSS WORKSHEET}

Heat Loss of Home

Min. R-value:

Heat Loss

$\left(\right.$ Btuh $\left./{ }^{\circ} \mathrm{F}\right)$

$$
\begin{aligned}
& \mathrm{R} \geq 9^{\text {Walls }}=\frac{\mathrm{sq} \mathrm{ft}}{\mathrm{R}_{\mathrm{f}} \text { of walls }}=\frac{1079}{8.2}=\underline{132} \\
& \mathrm{R} \geq 12.5=\frac{\mathrm{sq} f t}{\mathrm{R}_{\mathrm{f}} \text { of ceiling }}=\frac{952}{13.6}=\underline{70} \\
& R \geq 12^{\text {Floors }}=\frac{\text { sq } f t}{R_{f} \text { of floor }}=\frac{952}{14.1}=\underline{68} \\
& \text { Windows }=\frac{\mathrm{sq} \mathrm{ft}}{\mathrm{R} \text { of windows }}=\frac{117}{0.88}=\underline{133} \\
& \text { Doors }=\frac{\mathrm{sq} \mathrm{ft}}{\mathrm{R} \text { of doors }}=\frac{34}{1.85}=\frac{18}{421} \\
& \text { TOTAL }=\underline{532}\left(\mathrm{Btuh} /{ }^{\circ} \mathrm{F}\right)
\end{aligned}
$$

Calculation of Minimum Design Temperature

The greater of:

$$
\begin{aligned}
& 40 \mathrm{Btuh} / \mathrm{sq} \mathrm{ft} \times \underline{952} \mathrm{sq} \mathrm{ft}=\frac{38080}{(\mathrm{Btuh}) /{ }^{\circ} \mathrm{F}}=\frac{38080}{532}=\underline{72^{\circ} \mathrm{F}}(\mathrm{TD} \max .) \\
& 267 \mathrm{Btuh} / \mathrm{lin} \mathrm{ft} \times \underline{164} \mathrm{lin} \mathrm{ft}=\frac{43788}{(\mathrm{Btuh}) /{ }^{\circ} \mathrm{F}}=\frac{43788}{532}=\underline{82^{\circ} \mathrm{F}}(\mathrm{TD} \max .)
\end{aligned}
$$

Minimum Outdoor Design Temperature

$=$ Indoor design temp. $-\mathrm{TD}=\underline{70^{\circ}}-\underline{82^{\circ}}=\underline{-12^{\circ} \mathrm{F}}$ (Outdoor design temp.)

*111 $\times$ TD method per NFPA 501B.

Figure D-5. Heat loss worksheet for 1971 ANSI standard for electrically heated mobile home.? 
HEAT LOSS WORKSHEET

Heat Loss of Home

Min. R-values:

Heat Loss

(Btuh $/{ }^{\circ} \mathrm{F}$ )

$$
\begin{aligned}
& \mathrm{R} \geq 8^{\text {Wa1ls }}=\frac{\mathrm{sq} \mathrm{ft}}{\mathrm{R}_{\mathrm{f}} \text { of walls }}=\frac{1079}{8.2}=\underline{132} \\
& \mathrm{R} \geq 16 \stackrel{\text { Ceilings }}{=} \frac{\mathrm{sq} \mathrm{ft}}{\mathrm{R}_{\mathrm{f}} \text { of ceiling }}=\frac{952}{16.0}=\underline{60} \\
& R \geq 10^{\text {Floors }}=\frac{s q \mathrm{ft}}{\mathrm{R}_{\mathrm{f}} \text { of floor }}=\frac{952}{10.6}=\underline{90} \\
& \text { Windows }=\frac{\mathrm{sq} \mathrm{ft}}{\mathrm{R} \text { of windows }} . \quad=\frac{117}{0.88}=\underline{133} \\
& \text { Doors }=\frac{\mathrm{sq} f \mathrm{t}}{\mathrm{R} \text { of doors }}=\frac{34}{1.85}=\frac{18}{433} \\
& \text { TOTAL }=\underline{544}\left(\mathrm{Btuh} /{ }^{\circ} \mathrm{F}\right)
\end{aligned}
$$

Calculation of Minimum Design Temperature

The greater of:

$40 \mathrm{Btuh} / \mathrm{sq} \mathrm{ft} \times \underline{952} \mathrm{sq} \mathrm{ft}=\frac{38080}{(\mathrm{Btuh}) /{ }^{\circ} \mathrm{F}}=\frac{38080}{544}=\underline{70^{\circ} \mathrm{F}}(\mathrm{TD} \max$.

$275 \mathrm{Btuh} / 1$ in $\mathrm{ft} \times \underline{164}$ lin $\mathrm{ft}=\frac{45100}{(\mathrm{Btuh}) /{ }^{\circ} \mathrm{F}}=\frac{45100}{544}=83^{\circ} \mathrm{F}(\mathrm{TD} \max$.

Minimum Outdoor Design Temperature

$=$ Indoor design temp. $-\mathrm{TD}=\underline{70^{\circ}}-\underline{83^{\circ}}=\underline{-13^{\circ} \mathrm{F}}$ (Outdoor design temp:)

* $111 \times$ TD method per NFPA 501B.

Figure D-6. Heat loss worksheet for 1974 ANSI standard.? 
HEAT LOSS WORKSHEET

\section{Heat Loss of Home}

Max. U-value:

Heat Loss

$0.157 \mathrm{Btu} / \mathrm{ft}^{2 \circ} \mathrm{F}$

(Btuh $/{ }^{\circ} \mathrm{F}$ )

$$
\begin{aligned}
& \text { Walls }=\frac{\mathrm{sq} \mathrm{ft}}{\mathrm{R}_{\mathrm{f}} \text { of walls }} \\
& =\frac{1079}{9.7}=111 \\
& \text { Ceilings }=\frac{\mathrm{sq} f t}{\mathrm{R}_{f} \text { of ceiling }} \\
& =\frac{952}{13.6}=\underline{70} \\
& \text { Floors }=\frac{\text { sq } f t}{R_{f} \text { of floor }} \\
& =\frac{952}{7.0}=\underline{136} \\
& \text { Windows }=\frac{\text { sq } \mathrm{ft}}{\mathrm{R} \text { of windows }} \\
& =\frac{117}{0.88}=133 \\
& \text { Duurs }=\frac{\text { sq } \mathrm{ft}}{\mathrm{R} \text { of doors }} \\
& =\frac{34}{1.85}=18 \\
& \mathrm{U}=\frac{\Sigma \mathrm{UA}}{\Sigma \mathrm{A}}=\frac{468}{3134}=0.149
\end{aligned}
$$

Figure D-7. Heat loss worksheet for 1976 HUD standard for mobile homes in Zone I. ${ }^{6}$ 
HEAT LOSS WORKSHEET

Heat Loss of Home

Max. U:

Heat Loss

(Btuh $/{ }^{\circ} \mathrm{F}$ )

$0.126 \mathrm{Btu} / \mathrm{ft}^{2}$ of storms required

$$
\begin{aligned}
& \text { Walls }=\frac{\text { sq } f t}{R_{f} \text { of walls }} \\
& =\frac{1079}{9.8}=\underline{110} \\
& \text { Ceilings }=\frac{\mathrm{sq} \mathrm{ft}}{\mathrm{R}_{\mathrm{f}} \text { of ceiling }}=\frac{952}{13.6}=\underline{70} \\
& \text { Floors }=\frac{\mathrm{sq} f t}{\mathrm{R}_{\mathrm{f}} \text { of floor }} \quad=\frac{952}{8.6}=\underline{111} \\
& \text { Windows }=\frac{\mathrm{sq} \mathrm{ft}}{\mathrm{R} \text { of windows }}=\frac{117}{1.79}=\underline{65} \\
& \text { (storms) } \\
& \text { Doors }=\frac{\mathrm{sq} f \mathrm{ft}}{\mathrm{R} \text { of doors }} \quad=\frac{34}{1.85}=\underline{18} \\
& \mathrm{U}=\frac{\Sigma \mathrm{UA}}{\Sigma \mathrm{A}}=\frac{374}{3134}=0.119
\end{aligned}
$$

Figure D-8. Heat loss worksheet for 1976 HUD standard for mobile home in Zone II. ${ }^{6}$ 
TABLE D-1

DESIGN TO MOBILE HOME STANDARDS

\begin{tabular}{|c|c|c|c|c|c|}
\hline \multirow[b]{2}{*}{ Standard } & \multirow[b]{2}{*}{ Locations } & \multirow[b]{2}{*}{ Windows* } & \multicolumn{3}{|c|}{$\begin{array}{c}\text { Amount of Insulation } \\
\text { (inches) }\end{array}$} \\
\hline & & & Wal1s & Ceiling & Floor \\
\hline \multicolumn{6}{|l|}{1969 ANSI } \\
\hline Gas Heat & A11 & $\mathrm{p}$ & $1-1 / 2$ & $2-1 / 2$ & 1 \\
\hline \multirow[t]{3}{*}{ Electric Heat } & $\star \star$ & $\mathrm{P}$ & $1-1 / 2$ & $3-1 / 2$ & $3-1 / 2$ \\
\hline & Cheyenne & $\mathrm{P}$ & $3-1 / 2$ & $3-1 / 2$ & $3-1 / 2$ \\
\hline & Minneapolis & $S$ & $3-1 / 2$ & $3-1 / 2$ & $3-1 / 2$ \\
\hline \multicolumn{6}{|l|}{1971 ANSI } \\
\hline Gas Heat & All & $\mathrm{P}$ & $1-1 / 2$ & $2-1 / 2$ & 1 \\
\hline Electric Heat & A11 & $\mathrm{P}$ & $2-1 / 2$ & $3-1 / 2$ & $3-1 / 2$ \\
\hline 1974 ANSI & $A 11$ & $\mathrm{P}$ & $2-1 / 2$ & $4-1 / 2$ & $2-1 / 2$ \\
\hline \multirow[t]{2}{*}{1976 HUD } & Zone $I * * *$ & $\mathrm{P}$ & $3-1 / 2$ & $3-1 / 2$ & \\
\hline & Zone II & $S$ & $3-1 / 2$ & $3-1 / 2$ & $1-1 / 2$ \\
\hline
\end{tabular}

${ }^{*} \mathrm{P}=$ single pane windows, $\mathrm{S}=$ storm windnws.

${ }^{*} \Lambda 11$ but Cheyenne and Minneapolis (i.e., winter design temperatures above $\left.3^{\circ} \mathrm{F}\right)$.

***Zone I cities are Atlanta, San Diego, and Miami. Zone II cities are Minneapolis, Cheyenne, Boston, Seattle, Kansas City, and Washington, D.C. 6 
INTERNAL DISTRIBUTION

1. S. I. Auerbach

2. M. Baker

3. S. E. Beall

4. D. J. Bjornstad

5. J. R. Buchanan

6. R. S. Carlsmith

7. W. S. Chern

8. C. V. Chester

9. F. A. Creswick

10. R. M. Davis

11. J. G. Delene

12. W. Fulkerson

13. V. O. Haynes

14. N. F. Hinkle

15. E. A. Hirst

16. C. C. Hopkins

17. P. L. Johnson

18. S. I. Kaplan

19. D. Kaserman

20. R. S. Livingston

21. H. M. Long

22-42. P. M. Love

43. J. W. Michel

44. R. E. Minturn
45. W. R. Mixon

46. J. C. Moyers

47. E. A. Nephew

48. D. L. O'Neal

49. H. Postma

50. M. W. Rosentha1

51. T. H. Row

52. R. L. Spore

53. E. G. Struxness

54. T. Takayama

55. D. B. Trauger

56. G. U. Ulrikson

57. D. J. Walukas

58. T. J. Wilbanks

59. H. E. Zittel

60. A. Zucker

61. Biology Division Library

62-63. Central Research Library

64. Document Reference Section

65-66. Energy Information Library

67. Laboratory Records, (RC)

68-70. Laboratory Records Dept.

71. ORNL Patent office

\section{EXTERNAL DISTRIBUTION}

72. Institute of Energy Analysis, ORAU - Library

73. Research and Technical Support Division, DOE-ORO

74-100. Technical Information Center, DOE, P. 0. Box 62, Oak Ridge, Temiessee 37830

101-700. External Energy Conservation Distribution Mailing List and Energy Conservation Section Office (450oN, H32) 